\title{
Synthetic routes to benzimidazole-based fused polyheterocycles
}

\author{
Kamal M. Dawood, ${ }^{a, *}$ and Bakr F. Abdel-Wahab ${ }^{b}$ \\ ${ }^{a}$ Chemistry Department, Faculty of Science, Cairo University, Giza 12613, Egypt \\ ${ }^{b}$ Applied Organic Chemistry Department, National Research Centre, Dokki, Giza, Egypt \\ E-mail: $\underline{d r \text { dawood@yahoo.com }}$
}

\begin{abstract}
The review article represents a survey covering the synthetic strategies leading to benzimidazolebased fused polyheterocyclic systems utilizing simple reactive benzimidazole synthons since 1980. The polyheterocyclic systems are classified based on the number of rings; tetra-, penta-, hexa- and hepta-fused ring systems. Among each polyheterocyclic system, further classification according to the number of heterotoms; two-, three-, four-, five-, six- and seven heteroatoms is considered.
\end{abstract}

Keywords: Polyheterocycles, fused benzimidazoles, synthesis, cyclization

\section{Table of Contents}

1. Introduction

2. Tetracyclic fused benzimidazoles

2.1. With two heteroatoms

2.2. With three heteroatoms

2.3. With four heteroatoms

2.4. With five heteroatoms

2.5. With six heteroatoms

3. Pentacyclic fused benzimidazoles

3.1. With two heteroatoms

3.2. With three heteroatoms

3.3. With four heteroatoms

3.4. With five heteroatoms

3.5. With six heteroatoms

3.6. With seven heteroatoms

4. Hexa- and heptacyclic fused benzimidazoles

5. References 


\section{Introduction}

There is a growing interest over the past years for the synthesis of benzimidazole-based heterocycles due to the crucial role of benzimidazole unit in the functions of biologically important molecules. ${ }^{1-3}$ Benzimidazole-based ployhetrocycles has exhibited interesting biological properties. For example, benzimidazoquinazolines, ${ }^{4-8}$ benzimidazoisoquinolines ${ }^{9}$ and benzimidazo[2,1- $a$ ]isoindolones ${ }^{10}$ were reported as potent antitumor agents. Benzimidazo[2,1$b]$ quinazolines are potent immuno-suppressors ${ }^{11}$ and benzimidazo[2,1- $\left.b\right]$ benzo[f]isoquinoline ring system ${ }^{12}$ is present in pharmacologically active compounds. Isoindolo[2,1-a]benzimidazoles are also known to be sedatives and tranquilizers. ${ }^{13}$ There have been a number of practically important routes to benzimidazole-based polyheterocycles, e.g. (i) the reaction of benzaldehyde derivatives with benzimidazoles containing an activated methylene group at position 2, (ii) the reaction of coumarins with $o$-phenylenediamines, (iii) the reaction of 2-azidoanilines with substituted cinnamaldehydes, $(i v)$ the reaction of 2-(2-aminoaryl(hetaryl))benzimidazoles with haloketones, $(v)$ the reaction of $o$-phenylenediamines with phthalic anhydrides, ( $v i)$ metalcatalyzed cyclization of alkynylaniline derivatives and (vii) the reaction of 2(hydroxymethylene)-3-keto steroids with funtionalized benzimidazoles. Such reactions provide convenient strategies for synthesis of annulated benzimidazole polyheterocycles. This review covers the literature from 1980 to 2009.

\section{Tetracyclic fused benzimidazoles}

\subsection{With two heteroatoms}

2.1.1. Isoindolo-benzimidazoles. The preparation of isoindolo[2,1-a]benzimidazol-11-one derivatives was mostly performed from the condensation reaction of $o$-phenylenediamines with phthalic anhydrides. Thus, heating a mixture of $o$-phenylenediamines 1 with phthalic anhydrides 2 in acetic anhydride at $140-150{ }^{\circ} \mathrm{C}$ gave $11 H$-isoindolo[2,1-a]benzimidazol-11-one derivatives 3 (Scheme 1). ${ }^{14,15}$

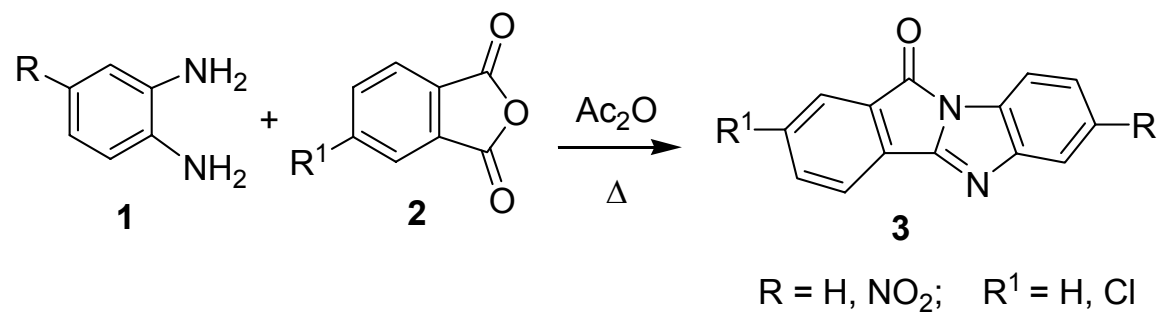

\section{Scheme 1}


Heating of 2-nitro-3-methylaniline 4 and phthalic anhydride 2 in $n$-amyl alcohol gave $N$-(2nitro-3-methylphenyl)phthalimide 5. Reaction of 5 with iron powder in 50\% aqueous acetic acid at $100{ }^{\circ} \mathrm{C}$ gave 6-methyl-11-oxoisoindolo[2,1-a]benzimidazole 6 (Scheme 2). ${ }^{16}$

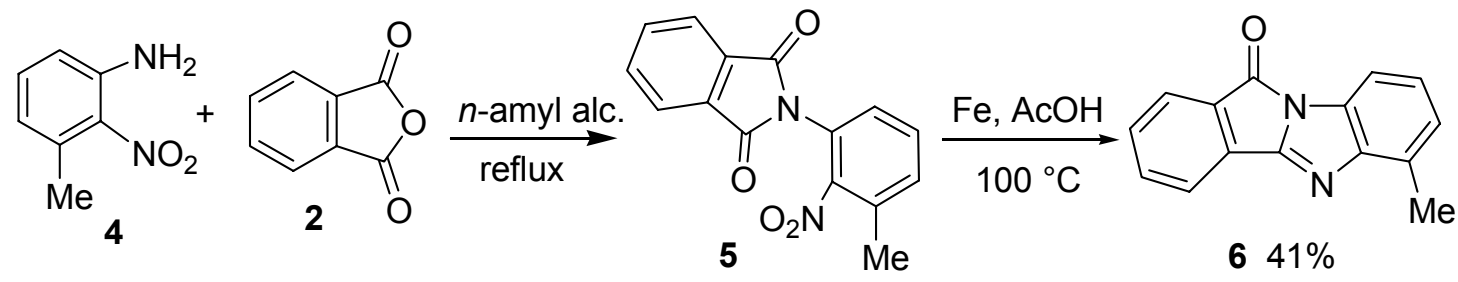

\section{Scheme 2}

The isoindolobenzimidazolone derivative $\mathbf{8}$ was obtained similarly from heating of phthalic anhydride 2 with the pyridyl-phenylenediamine derivative 7 (Scheme 3 ). ${ }^{17}$<smiles>COC(=O)C1=C(C)NC(C)=C(C(C)=O)C1c1cccc(N)c1N</smiles>

\section{Scheme 3}

The hydroxyisoindolobenzimidazole derivatives $\mathbf{1 0}$ and $\mathbf{1 2}$ were synthesized from $o$ phenylenediamine 1 and 3-benzylidenephthalide 9 and with the 1,2-di(triflouroacetyl)benzene 11, respectively (Scheme 4). ${ }^{18,19}$<smiles>[R]C1(C(F)(F)F)c2ccccc2C2(C(F)(F)F)Nc3ccccc3N12</smiles><smiles>CC(C)(F)C(=O)c1ccccc1C(=O)C(F)(F)F</smiles><smiles>Nc1ccccc1N</smiles><smiles>O=C1O/C(=C\c2ccccc2)c2ccccc21</smiles><smiles>OC12Nc3ccccc3/C(=C\c3ccccc3)N1c1ccccc12</smiles>

\section{Scheme 4}


Condensation of $o$-phenylenediamine 1 with $o$-acylbenzoic acids $\mathbf{1 3}$ in refluxing toluene using catalytic amount of $p$-toluenesulfonic acid (PTSA) under azeotropic condition for removal of water, led to the formation of isoindolobenzimidazoles $\mathbf{1 4}$ in reasonable yields (Scheme 5). ${ }^{20,21}$ Similar condensation of $\mathbf{1}$ with aroylcyclohexane-carboxylic acids $\mathbf{1 5}$ gave the hexahydroisoindolobenzimidazoles 16 (Scheme 5). ${ }^{22,23}$

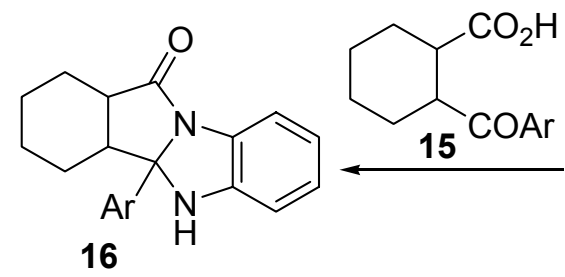

$\mathrm{Ar}=\mathrm{Ph}, 4-\mathrm{MeC}_{6} \mathrm{H}_{4}$<smiles>Nc1ccccc1N</smiles>

1

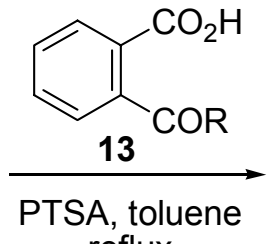
reflux<smiles>[R]C12Nc3ccccc3N1C(=O)c1ccccc12</smiles>

14

$\mathrm{R}=\mathrm{H}, \mathrm{Me}, \mathrm{Ph}, 4-\mathrm{MeC}_{6} \mathrm{H}_{4}$

\section{Scheme 5}

Reaction of dibenzo[b,f][1,4]diazocine-6,11-(5H,12H)-dione $\mathbf{1 7}$ with 2-azidobenzoyl chloride 18 in DMF and $\mathrm{NaH}$ afforded only $30 \%$ yield $4 \mathrm{~b}$-[(2-azidobenzoy1)oxy]-5Hisoindolo[2,1-a]benzimidazol-11(4bH)-one 19 via transannular cyclization (Scheme 6). ${ }^{24}$<smiles>O=C1Nc2ccccc2NC(=O)c2ccccc21</smiles>

17<smiles>Nc1ccccc1C(=O)Cl</smiles>

18<smiles>CC(C)[C@H](C)C(=O)OC12Nc3ccccc3N1C(=O)c1ccccc12</smiles>

19

\section{Scheme 6}

The parent $11 H$-isoindolo[2,1-a]benzimidazole could also be obtained via an intramolecular aryl radical cyclization as shown in Scheme 7. Thus, heating a mixture of 2chlorobenzimidazole 20, arenethiol and 2-iodobenzyl iodide 21 in DMF in the presence of $\mathrm{KOH}$ / $\mathrm{KOBu}^{t}$ under reflux gave a quantitative yield of the 2-arylthio-1-benzyl-1H-benzimidazole derivative 22. Five-membered cyclisation with the radical precursor 22 using tris(trimethylsilyl)silane (TTMSS) in toluene at reflux afforded a low yield (20\%) of the cyclised product $11 H$-isoindolo[2,1-a]benzimidazole $\mathbf{2 3}$ via a homolytic aromatic substitution by aryl radical at $\mathrm{C}-2$ of benzimidazole ring (Scheme 7$).{ }^{25}$ 
<smiles>Clc1nc2ccccc2[nH]1</smiles>

20<smiles>ICc1ccccc1I</smiles>

21

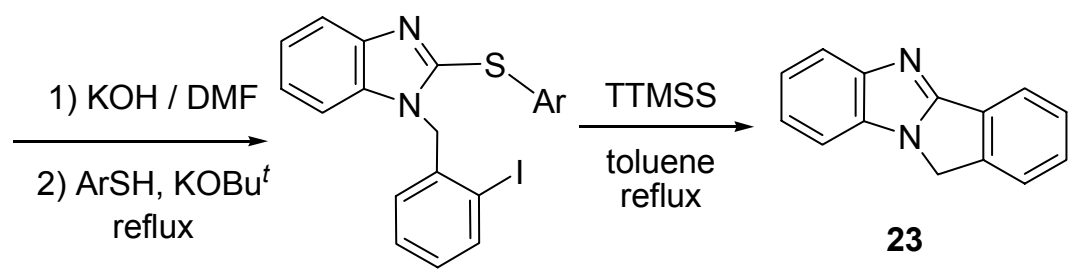

$\mathrm{Ar}=4-\mathrm{CO}_{2} \mathrm{H}-\mathrm{C}_{6} \mathrm{H}_{4}$

\section{Scheme 7}

7-Methoxy-11H-isoindolo[2,1-a]benzimidazole 25 was prepared in 90\% yield from palladium-catalyzed annulation of 2-(4-methoxy-2-nitrophenyl)-2,3-dihydro-1 $H$-isoindole 24 by heating in DMF using bis-(dibenzylideneacetone)palladium [ $\left.\mathrm{Pd}(\mathrm{dba})_{2}\right]$ and 1,10-phenanthroline at $120{ }^{\circ} \mathrm{C}$ and the solution was saturated with $\mathrm{CO}$ under pressure (Scheme 8). ${ }^{26}$

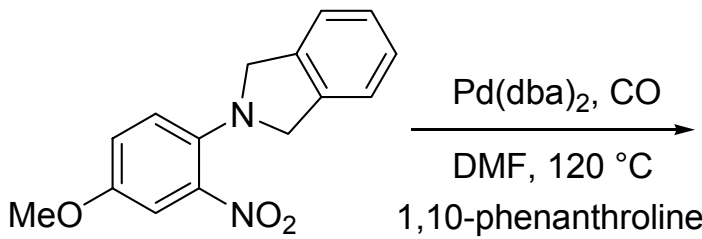

24<smiles>COc1ccc2c(c1)nc1n2Cc2ccccc2-1</smiles>

$25,90 \%$

\section{Scheme 8}

2.1.2. Benzimidazo[2,1-a]isoquinolines. Condensation of $o$-phenylenediamine 1 with 2-(2phenylethynyl)benzaldehyde $\mathbf{2 6}$ in refluxing nitrobenzene resulted in an oxidative cyclization to give 6-phenylbenzimidazo[2,1-a] isoquinoline $\mathbf{2 9}$ via the intermediates 27 and 28 (Scheme 9). ${ }^{27}$

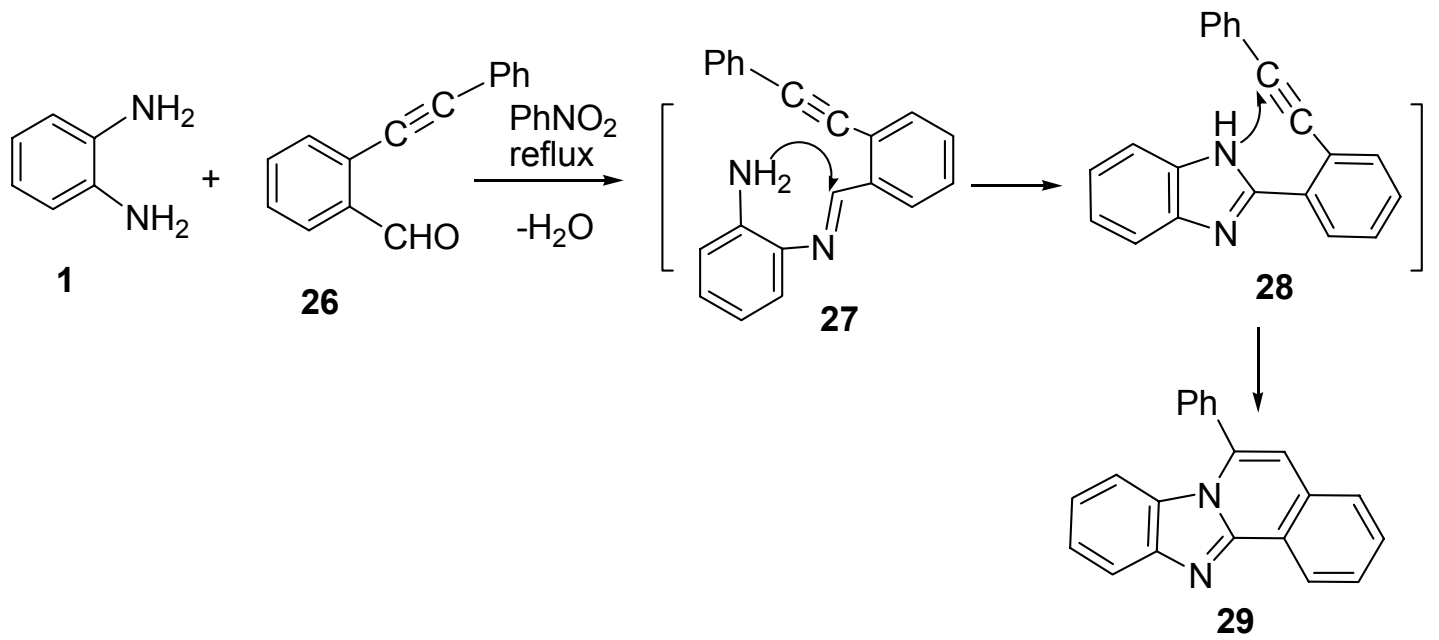

\section{Scheme 9}


Direct, efficient syntheses of the benzimidazo[2,1- $a$ isoquinolines 32 have been achieved with 2-bromoarylaldehydes 30, terminal alkynes 31, and 1,2-phenylenediamines $\mathbf{1}$ by a microwave-accelerated tandem process in which a Sonogashira coupling, 5-endo cyclization, oxidative aromatization, and 6-endo cyclization could be performed in a single synthetic operation (Scheme 10). ${ }^{28}$

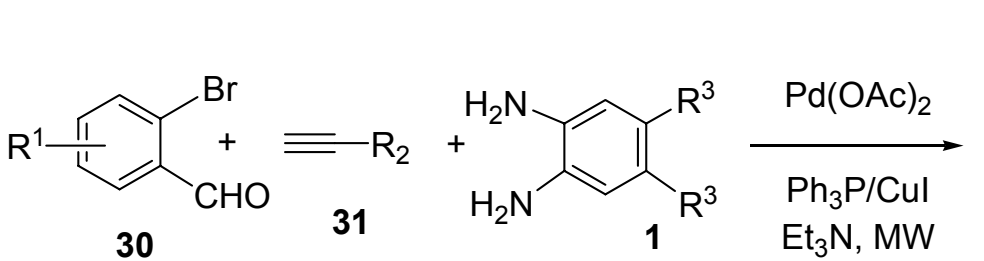

$\mathrm{R}^{1}=\mathrm{H}, 4-\mathrm{Me}, 5-\mathrm{F}$<smiles>[R]Cc1ccc2cc([R])n3c4cc([R])c([R])cc4nc3c2c1</smiles>

$32 \quad 68 \sim 83 \%$

\section{Scheme 10}

Heating of $N$-(5-methoxy-2-nitrophenyl)-1,2,3,4-tetrahydroisoquinoline 33 in acetic acid resulted in an intramolecular cyclization to give the benzimidazo[2,1- $a$ ] isoquinoline- $N$-oxide 34 which upon deoxygenation via heating with $\mathrm{PCl}_{3}$ in chloroform gave the benzimidazo[2,1a] isoquinoline derivative 35 (Scheme 11) ${ }^{29}$

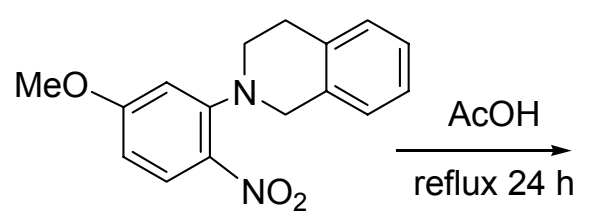

33

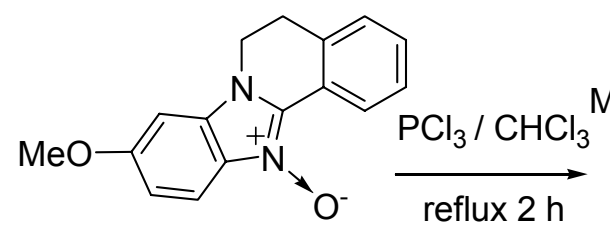

34<smiles>Oc1ccc2nc3n(c2c1)CCc1ccccc1-3</smiles>

35

\section{Scheme 11}

The reaction of 2-azidoaniline $\mathbf{3 6}$ with aromatic aldehydes gave N-(2-azidophenyl)imines $\mathbf{3 7}$ which upon reaction with trimethylphosphine followed with diphenylketene $\mathbf{3 8}$, the corresponding 6,11-dihydrobenzimidazo[1,2-b]isoquinolines $\mathbf{4 0}$ were isolated in excellent yields via a formal [4+2] intramolecular cycloaddition of ketenimine with imine function of the intermediates 39. Refluxing of $\mathbf{4 0}$ with $\mathrm{Pd} / \mathrm{C}$ in toluene gave benzimidazo[1,2-b]isoquinolines $\mathbf{4 1}$ in good yields (Scheme 12). ${ }^{30,31}$ 
<smiles>Nc1ccccc1N=CC(C=O)C(=O)O</smiles>

36

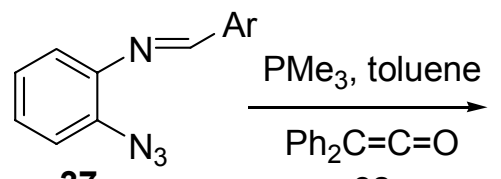

38<smiles>Cc1ccc(N=C=C(c2ccccc2)c2ccccc2)c(C)c1</smiles>

39

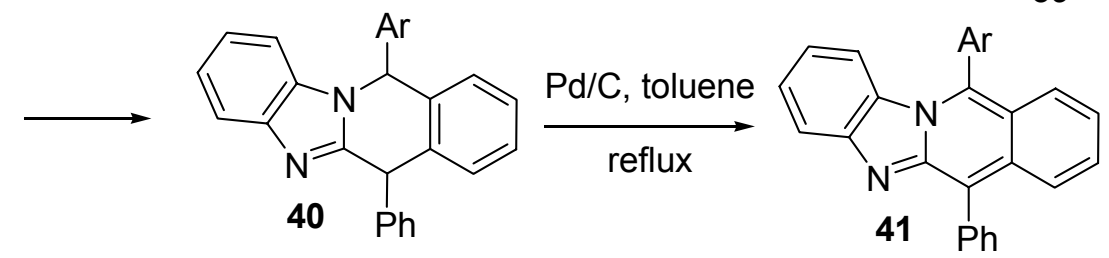

$$
\mathrm{Ar}=4-\mathrm{ClC}_{6} \mathrm{H}_{4}, 4-\mathrm{NO}_{2} \mathrm{C}_{6} \mathrm{H}_{4}, 4-\mathrm{CNC}_{6} \mathrm{H}_{4}, 4-\mathrm{MeC}_{6} \mathrm{H}_{4}
$$

\section{Scheme 12}

2-Benzimidazoleacetonitrile 42 condensed with 2-haloaromatic esters 43 in refluxing acetonitrile containing $\mathrm{K}_{2} \mathrm{CO}_{3}$ to give the benzimidazo[1,2- $a$ ]isoquinolones 44 (Scheme 13). ${ }^{32-34}$

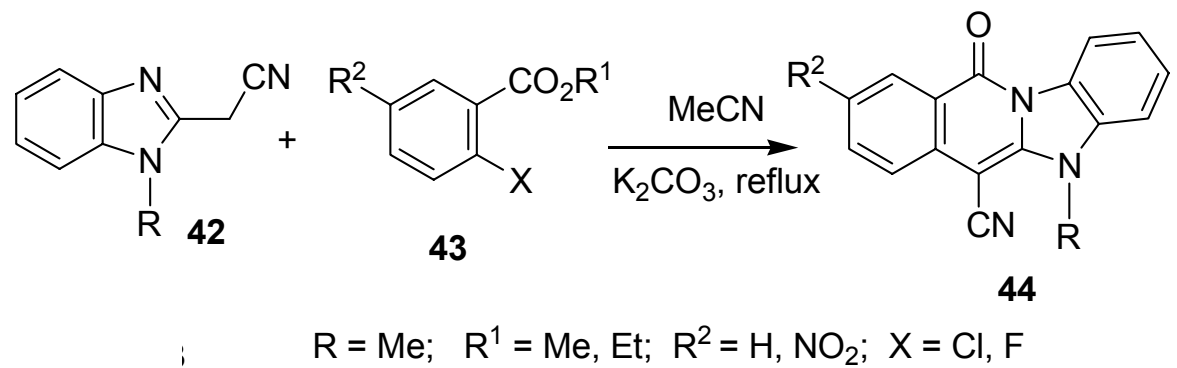

\section{Scheme 13}

Benzimidazo[1,2-a]isoquinolines 46 were prepared in reasonable yield by condensing 2benzimidazoleacetonitrile 42 with ethyl cycloalkanone-2-carboxylates 45 in the presence of ammonium acetate at $140{ }^{\circ} \mathrm{C}$ (Scheme 14). ${ }^{35,36}$<smiles>N#CCc1nc2ccccc2[nH]1</smiles>

42

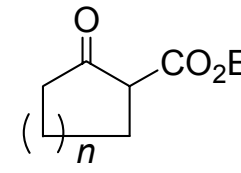

45

$$
n=1,2,3,4
$$

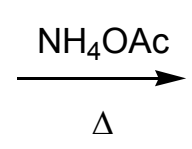

$\Delta$<smiles>[R]n1c2ccccc2n2c(=O)c3c(c(C#N)c12)CCC3</smiles>

$46 \quad 15-92 \%$

\section{Scheme 14}


Refluxing of isochroman-1,3-dione 47 with $o$-phenylenediamine 1 in acetic acid gave $11 H$ benzimidazo[1,2-a]isoquinolin-11-one 48 (Scheme 15). ${ }^{37}$<smiles>[13CH3]c1ccccc1N</smiles>

\section{Scheme 15}

Substituted $5 H$-benzimidazo[1,2- $b$ ]isoquinolin-11-ones 50 were synthesized in good yields (53-83\%) by refluxing, in $n$-amyl alcohol, the appropriate $o$-phenylenediamine 1 with $\alpha$ - $(o$ carboxyphenyl)acetonitriles 49 (Scheme 16). ${ }^{38}$

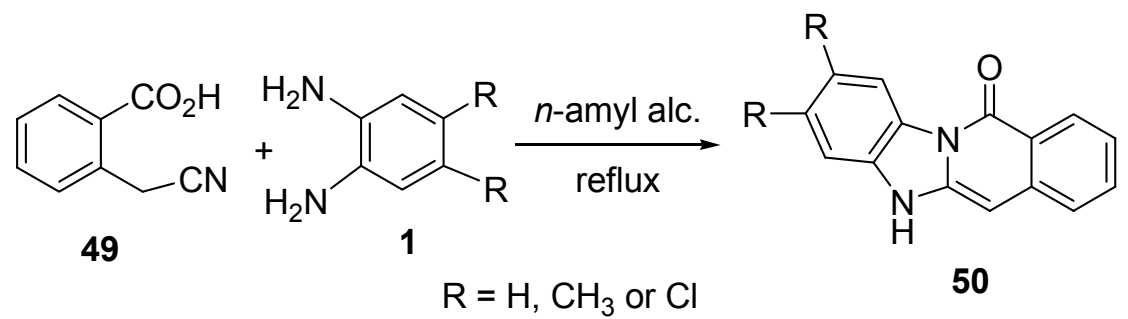

\section{Scheme 16}

2.1.3. Benzimidazo $[1,2-a]$ quinolines. Photochemical cyclization of arylidene- $1 H$-benzimidazol2-ylacetonitriles $\mathbf{5 1}$ yielded the bezimidazo[1,2-a]quinoline derivatives $\mathbf{5 2}$ (Scheme 17). ${ }^{39}$ Highly fluorescent 7-(diethylamino)benzimidazo[1,2-a]quinoline-3-carbonitrile 53 was prepared in 75\% yield by cyclization of the arylidene- $1 H$-benzimidazol-2-ylacetonitrile $51\left(\mathrm{X}=\mathrm{OMe}, \mathrm{R}=\mathrm{NEt}_{2}\right)$ under refluxing $o$-dichlorobenzene in the presence of piperidine and acetic acid (Scheme 17). ${ }^{40}$<smiles>[R]c1ccc2cc(C#N)c3nc4ccccc4n3c2c1</smiles>

$5375 \%$

$\mathrm{R}=\mathrm{NEt}_{2}$

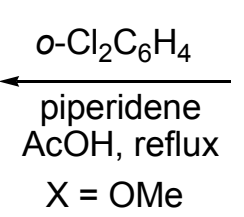

$$
\mathrm{X}=\mathrm{OMe}
$$<smiles>[R]c1ccc(/C=C(\C#N)c2nc3ccccc3[nH]2)c([X])c1</smiles>

$\mathrm{R}=\mathrm{H}, \mathrm{CN}, \mathrm{NEt}_{2}$

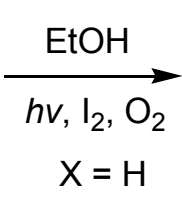

$\mathrm{X}=\mathrm{H}$

52 CN

$\mathrm{R}=\mathrm{H}, \mathrm{CN}$

\section{Scheme 17}


2- $N$-Ethylamino-5-methylbenzimidazo[1,2-a]quinoline 55 was formed in 18\% yield when 7diethylamino-4-methylcoumarin 54 reacted with $o$-phenylenediamine 1 in the presence of polyphosphoric acid (PPA) at $240{ }^{\circ} \mathrm{C}$ (Scheme 18). ${ }^{41}$<smiles>CCNc1ccc2c(C)cc(=O)oc2c1</smiles>

54

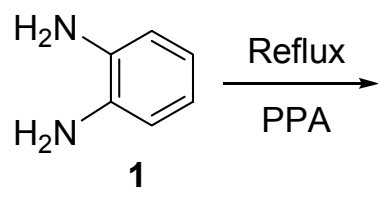

1<smiles>CCNc1ccc2c(C)cc3nc4ccccc4n3c2c1</smiles>

$55 \quad 26 \%$

\section{Scheme 18}

Arylidene-1H-benzimidazol-2-ylacetonitriles 56 underwent an intramolecular cyclization when heated in DMF containing triethylamine to give the benzimidazo[1,2-a]quinoline-6carbonitriles 57 (Scheme 19). ${ }^{42,43}$

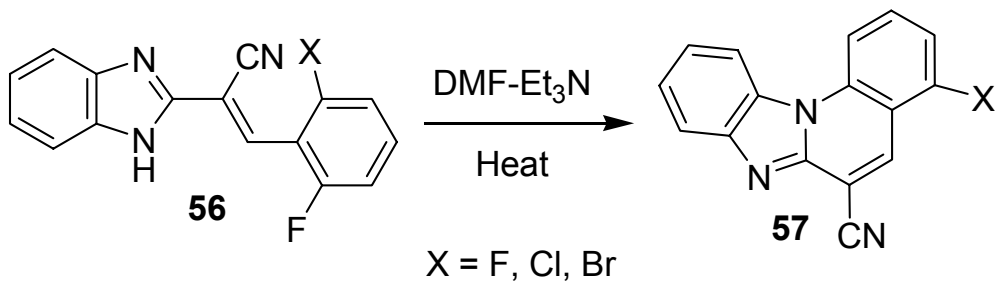

\section{Scheme 19}

Microwave irradiation of 2-(N,N-dimethylamino)methylene-5,5-dimethylcyclohexane-1,3dione 58 and 2-benzimidazoleacetonitrile 42 in iso-propanol and a catalytic amount of piperidine led to the formation of tetrahydrobenzimidazo[1,2-a]quinoline derivative $\mathbf{5 9}$ (Scheme 20). ${ }^{44}$<smiles>CN(C)C=C1C(=O)CC(C)(C)CC1=O</smiles>

58<smiles>[R]n1c(CC#N)nc2ccccc21</smiles>

42

$$
\mathrm{R}=\mathrm{H}
$$

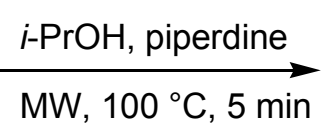

$\mathrm{MW}, 100^{\circ} \mathrm{C}, 5 \mathrm{~min}$<smiles>CC1(C)CC(=O)c2cc(C#N)c3nc4ccccc4n3c2C1</smiles>

\section{Scheme 20}


Room-temperature reactions of polyfluorobenzoyl chlorides $\mathbf{6 1}$ with 2benzoylmethylbenzimidazole $\mathbf{6 0}$ in dichloromethane in the presence of triethylamine afforded tetracyclic imidazoquinolines $\mathbf{6 3}$ in $73-81 \%$ yields via the intermediate $\mathbf{6 2}$ (Scheme 21). ${ }^{45}$

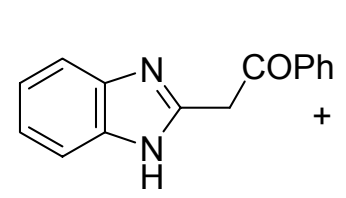

60<smiles>[X]c1c(F)c(F)c(F)c(C(=O)Cl)c1F</smiles>

61<smiles>[X]c1c(F)c(F)c(F)c(F)c1C(=O)C(C(=O)c1ccccc1)c1nc2ccccc2[nH]1</smiles>

62<smiles></smiles>

$6373-81 \%$

\section{Scheme 21}

2.1.4. Fused macroheterocycles with two heteroatoms. Chlorocyclohepta[b]pyrroles 64 reacted with $o$-phenylenediamine $\mathbf{1}$ to give 2-(2-aminoanilino)cyclohepta[$[b]$ pyrroles $\mathbf{6 5}$ in good yields. Treatment of $\mathbf{6 5}(\mathrm{R}=\mathrm{H})$ with polyphosphoric acid (PPA) afforded cycloheptapyrrolobenzimidazole $66(\mathrm{R}=\mathrm{H})$ in good yields and when $65\left(\mathrm{R}=\mathrm{CO}_{2} \mathrm{Et}\right)$ was treated with $\mathrm{TsOH}$ in $n$-butanol under reflux the ester derivative $\mathbf{6 6}\left(\mathrm{R}=\mathrm{CO}_{2} \mathrm{Et}\right)$ was obtained (Scheme 22). ${ }^{46}$<smiles>[R]C1=C2/C=C\C=C/C=C\C2N=C1Cl</smiles>

\section{Scheme 22}

Treatment of pyrido[1,2-a]benzimidazole 67 with dimethyl acetylenedicarboxylate $\mathbf{6 8}$ in benzene for $5 \mathrm{~h}$ at $20{ }^{\circ} \mathrm{C}$ gave the bis-pyridobenzimidazole derivative 69 in $44 \%$ yield (Scheme $23){ }^{47}$
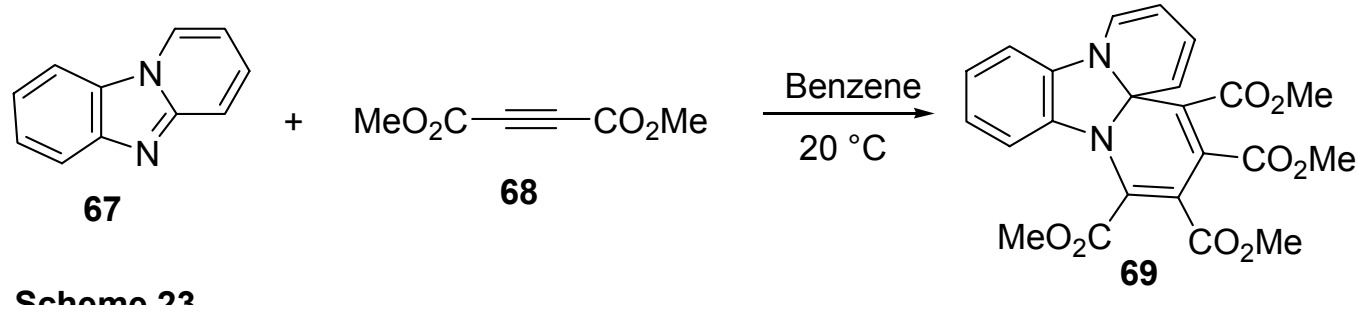


\section{Scheme 23}

The reaction of Baylis-Hillman acetate 71 with 2-substituted benzimidazoles 70 in DMF and $\mathrm{K}_{2} \mathrm{CO}_{3}$ at room temperature gave the benzimidazole-attached Baylis-Hillman adducts 72 in 67$89 \%$ yields. The tetracyclic compounds containing eight-membered ring; benzoazocinobenzimidazole derivatives $\mathbf{7 3}$ were formed, in 36-48\% yields, from the intramolecular palladium catalyzed cyclization of 72. Similarily, the seven-membered ring compounds $\mathbf{7 6}$ were obtained from the reaction of 71 with 2-unsubstituted benzimidazoles 74 in $\mathrm{DMF}$ and $\mathrm{K}_{2} \mathrm{CO}_{3}$ at room temperature to give the adducts $\mathbf{7 5}$. Intramolecular Pd-catalyzed cyclization of $\mathbf{7 5}$ resulted in the formation of benzo[3,4]azepino[1,2-a]benzimidazole derivatives $\mathbf{7 6}$ in reasonable yields. The latter results show that 2-position of benzimidazole is more reactive than that of 7-position (Scheme 24). ${ }^{48}$

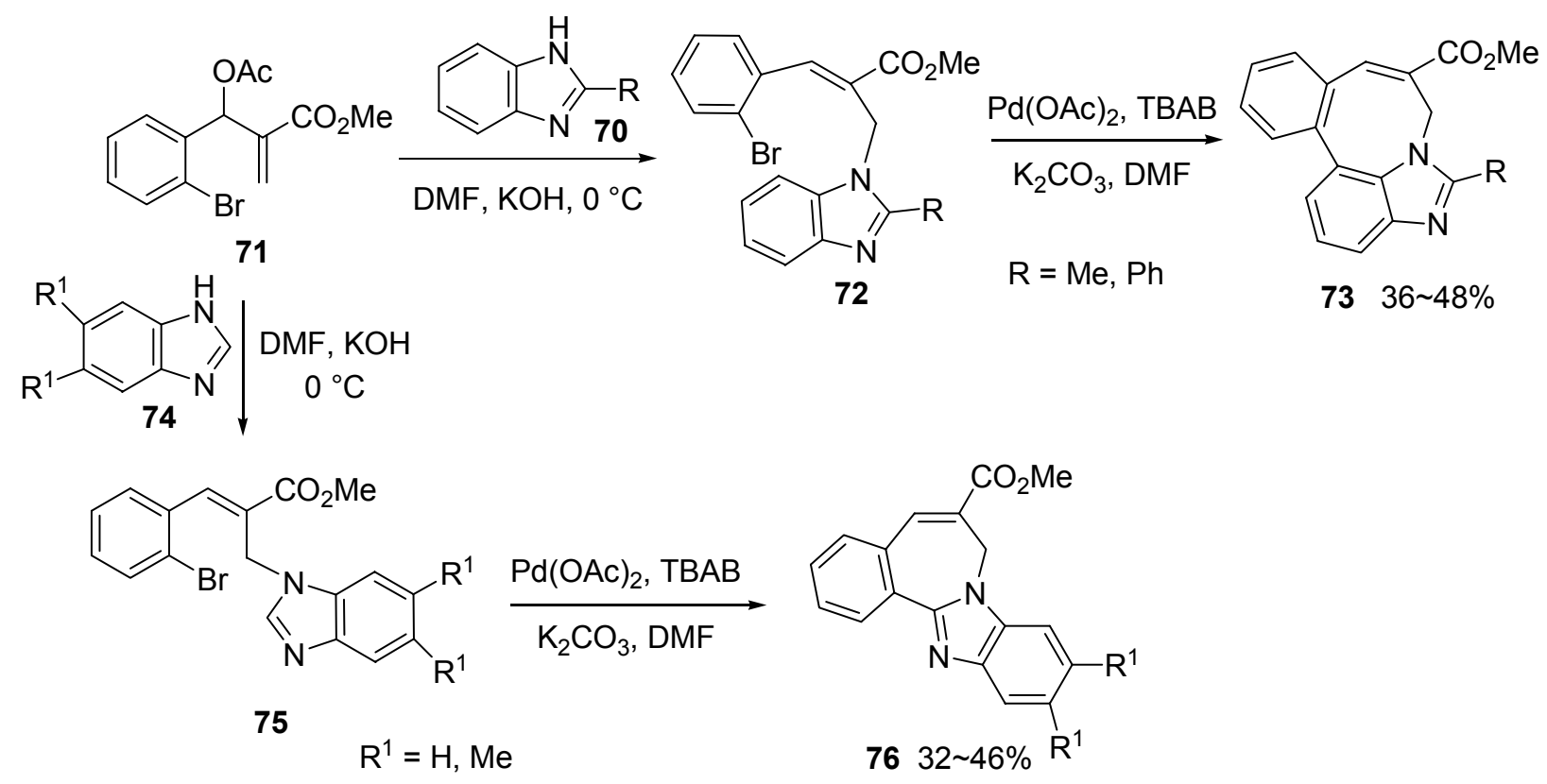

\section{Scheme 24}

\subsection{With three heteroatoms}

2.2.1. Pyrrolo-[3',4':4,5]pyrrolo[1,2-a]benzimidazoles. Condensation of 2-cyanomethylbenzimidazoles 42 with dichloromaleimide derivative 77 afforded the (1H-benzimidazol-2-yl)(3-pyrrolyl)acetonitriles 78. Intramolecular cyclization of $\mathbf{7 8}$ gave 1,3-dioxo-1,3dihydropyrrolo[3',4':4,5]pyrrolo[1,2-a] benzimidazoles 79 (Scheme 25). ${ }^{49}$ 


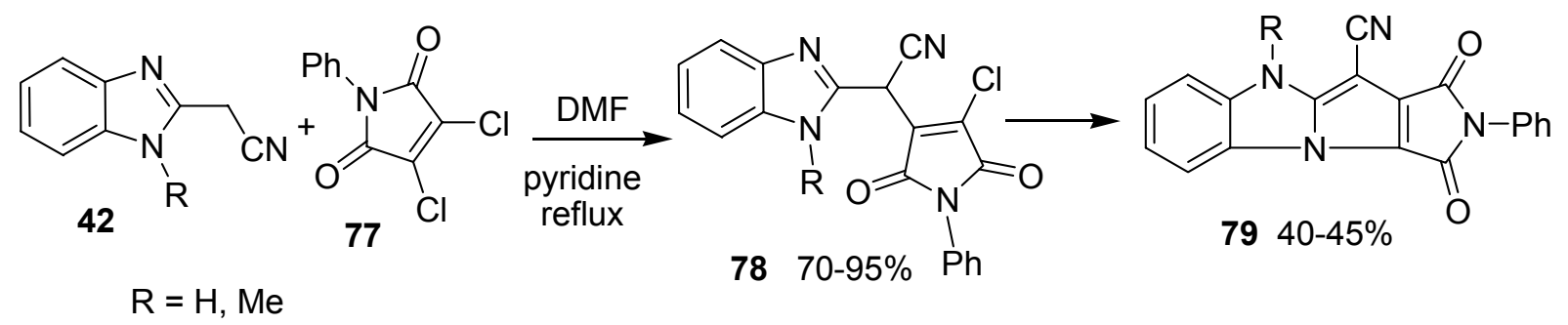

Scheme 25

2.2.2. Pyrrolo $\left[3^{\prime}, 4^{\prime}: 3,4\right]$ pyrido $[1,2-a]$ benzimidazoles. Condensation of 2-benzimidazoleacetonitrile $\mathbf{4 2}$ with ethyl 4-chloro-3-oxobutanoate $\mathbf{8 0}$ led to 3-chloromethylpyrido[1,2a]benzimidazole-4-carbonitrile $\mathbf{8 1}$ which upon amination with primary amines yielded pyrrolo[3',4':3,4]pyrido[1,2-a]benzimidazoles 82 (Scheme 26). ${ }^{50}$<smiles>N#CCc1nc2ccccc2[nH]1</smiles><smiles>CCOC(=O)CC(=O)CCl</smiles>

$\mathrm{R}=\mathrm{Bu}, \mathrm{Bn}, \mathrm{MeOCH}_{2} \mathrm{CH}_{2}$<smiles>N#Cc1c(CCl)cc(=O)n2c1[nH]c1ccccc12</smiles>

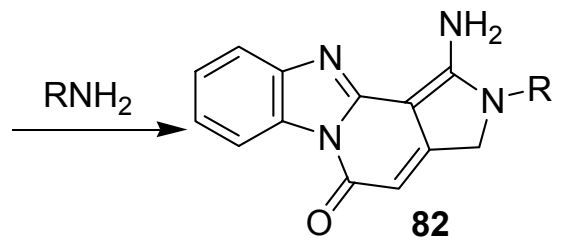

\section{Scheme 26}

2.2.3. Furo $\left[3^{\prime}, 2^{\prime}: 5,6\right]$ pyrido $[1,2-a]$ benzimidazoles. Furo $\left[3^{\prime}, 2^{\prime}: 5,6\right]$ pyrido[1,2- $\left.a\right]$ benzimidazole derivatives 84 were prepared by reaction of the hydroxy aldehyde 83 with activated alkyl halides in the presence of $\mathrm{K}_{2} \mathrm{CO}_{3}\left(\right.$ Scheme 27). ${ }^{51}$

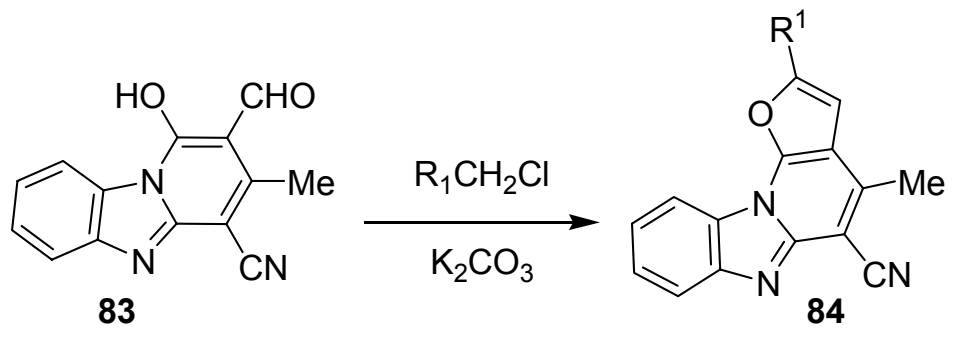

$$
\mathrm{R}^{1}=\mathrm{CO}_{2} \mathrm{Et}, \mathrm{CN}, \mathrm{Ph}, 2 \text {-benzimidazolyl }
$$

\section{Scheme 27}

2.2.4. Pyrano[4,3- $d]$ pyrido[1,2-a]benzimidazoles. Reaction of 6-aryl-3-cyano-4-methylthio$2 \mathrm{H}$-pyran-2-ones 85 with 2-cyanomethyl-benzimidazole 42 in $\mathrm{DMF}$ and $\mathrm{KOH}$ at $30{ }^{\circ} \mathrm{C}$ led to the formation of pyrano[4,3-d]pyrido[1,2-a]benzimidazoles 86 in low yields (7-20\%) (Scheme 28). ${ }^{52}$ 


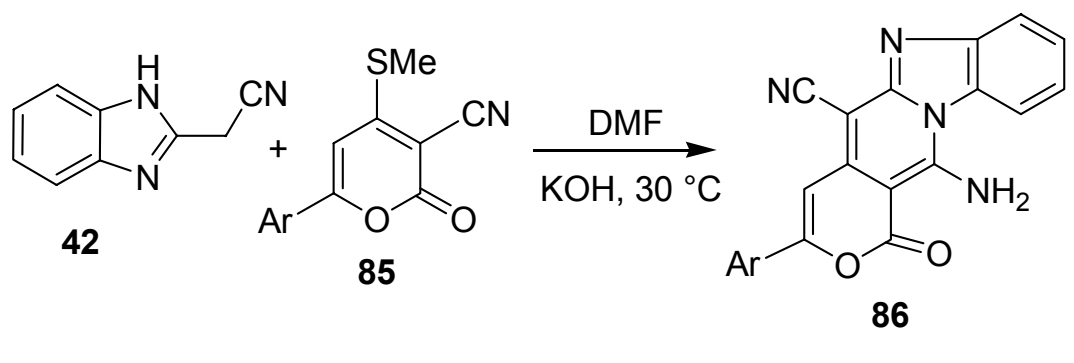

$\mathrm{Ar}=4-\mathrm{ClC}_{6} \mathrm{H}_{4}, 4-\mathrm{FC}_{6} \mathrm{H}_{4}, 4-\mathrm{BrC}_{6} \mathrm{H}_{4}, 4-\mathrm{MeC}_{6} \mathrm{H}_{4}, 3-\mathrm{MeOC}_{6} \mathrm{H}_{4}$

\section{Scheme 28}

2.2.5. Thieno[2,3-b]pyrido[1,2-a]benzimidazoles. Badawey et al reported the reaction of chloropyrido[1,2-a]benzimidazole derivatives 87 with thiourea in refluxing ethanol to give thieno[2,3-b]pyrido[1,2-a] benzimidazole derivatives 88. Treatment of $\mathbf{8 7}$ with anilines in refluxing DMF gave the $1 H$-pyrrolo[2,3-b]pyrido[1,2- $a$ ] benzimidazole derivatives 89 (Scheme 29). ${ }^{53}$<smiles>[R]c1cc2c(cc1[R])NC1C(C#N)=C(C)C(CCO)=C(Cl)N1c1cc([R])c([R])cc1N2</smiles>
$\mathrm{Ar}=4-\mathrm{ClC}_{6} \mathrm{H}_{4}, 4-\mathrm{F}-\mathrm{C}_{6} \mathrm{H}_{4}, 4-\mathrm{MeC}_{6} \mathrm{H}_{4}, 3-\mathrm{MeOC}_{6} \mathrm{H}_{4}$

$\mathrm{R}=\mathrm{H}, \mathrm{Me}$

Scheme 29

2.2.6. Benzimidazo[2,1-b]-1,3-benzothiazine. Reaction of benzimidazole-2-thiol 90 with pentafluorobenzoyl chloride $\mathbf{6 1}$ in pyridine at room temperature for 30 minutes gave 1,2,3,4tetrafluoro-12H-benzimidazo[2,1-b][1,3] benzothiazin-12-one 91 in 50\% yield (Scheme 30$){ }^{54}$<smiles>O=C(Cl)c1c(F)c(F)c(F)c(F)c1F</smiles>

\section{Scheme 30}

2.2.7. Benzimidazo[1,2-c]quinazolines. The benzimidazo[1,2-c]quinazoline derivatives 94 were obtained in high yields from the cyclocondensation reaction of 2-(2-aminophenyl)benzimidazole 92 with ortho-esters in dimethylacetamide (DMA) under microwave irradiation. ${ }^{55}$ The same 
product $94(\mathrm{R}=\mathrm{H})$ was prepared from treatment of 2-(2-nitrophenyl)benzimidazole derivative 93 with triethyl-orthoformate in the presence of $\mathrm{TiCl}_{4}-\mathrm{Zn}$ (Scheme 31$) .{ }^{56,57}$<smiles>Nc1ccccc1-c1nc2ccccc2[nH]1</smiles>

92

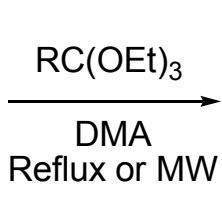

Reflux or MW<smiles>[R]c1nc2ccccc2c2nc3ccccc3n12</smiles>

94

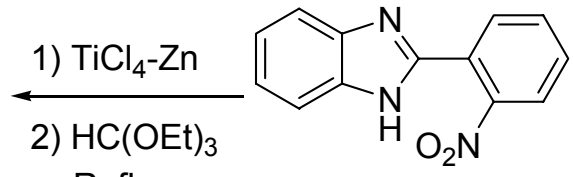

Reflux

93

$$
\mathrm{R}=\mathrm{H}, \mathrm{Me}, \mathrm{Et}, n-\mathrm{Pr}
$$

\section{Scheme 31}

6-Cyanobenzimidazo[1,2-c] quinazoline 97 was prepared in 50\% yield by treatment of 2-(2aminophenyl)benzimidazole 92 with 4,5-dichloro-1,2,3-dithiazolium chloride (Appel salt) 95, in chloroform at room temperature in the presence of pyridine, via the intermediate 96 (Scheme $32){ }^{58}$<smiles>NC1=CC=[C+]C=C1c1nc2ccccc2[nH]1</smiles>

92<smiles>Clc1[c-]snc1Cl</smiles>

95

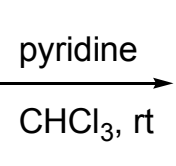

$\mathrm{CHCl}_{3}, \mathrm{rt}$<smiles>C1CCCC1</smiles><smiles>N#Cc1nc2ccccc2c2nc3ccccc3n12</smiles>

\section{Scheme 32}

The cyano group in position 2 of the benzothiazole ring is very reactive and its transformation into acid, amide, amidine and imidate may be easily realised. Thus, microwave irradiation of 2-cyanobenzothiazole 98 with 2-(2-aminophenyl)benzimidazole 92 at $220{ }^{\circ} \mathrm{C}(150$ Watt), in the presence of graphite, resulted in the formation of 6-(2benzothiazolyl)benzimidazo[1,2-c] quinazolines 99 in good yields (Scheme 33). ${ }^{59}$

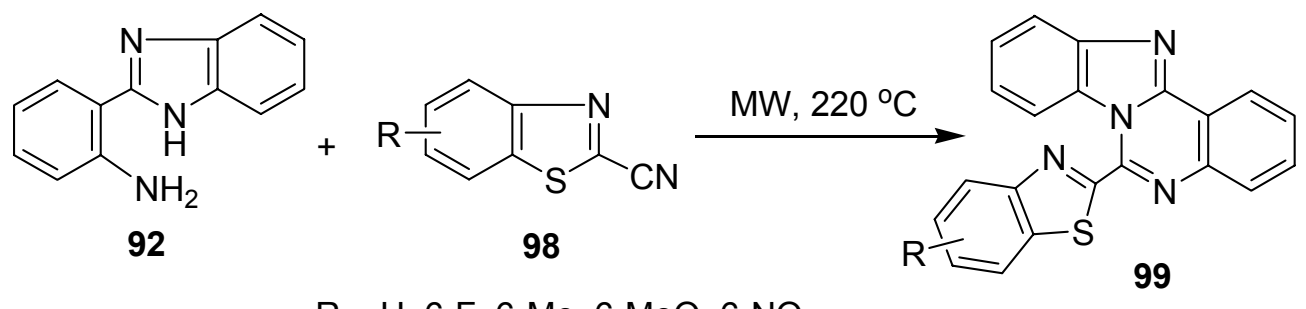

$\mathrm{R}=\mathrm{H}, 6-\mathrm{F}, 6-\mathrm{Me}, 6-\mathrm{MeO}, 6-\mathrm{NO}_{2}$

\section{Scheme 33}


The 6-mercaptobenzimidazo[1,2-c]quinazoline $\mathbf{1 0 0}$ was easily accomplished by the reaction of 92 with carbon disulphide in the presence of methanolic potassium hydroxide either under microwave irradiation at $60{ }^{\circ} \mathrm{C}$ or conventional heating (Scheme 34). ${ }^{60,61}$ Compound 100 was alternatively prepared by cyclization of 3-(2-aminophenyl)-4-oxoquinazoline-2-thione 101 in refluxing DMF in the presence of acetic acid (Scheme 34$){ }^{62}$<smiles>Nc1ccccc1-c1nc2ccccc2[nH]1</smiles>

92<smiles>Sc1nc2ccccc2c2nc3ccccc3n12</smiles>

100<smiles>CC(C)(C)C(=O)O</smiles>
reflux

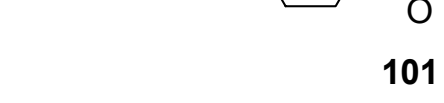

\section{Scheme 34}

Mahana et al. reported the conversion of 1H-2-benzimidazol-2-ylbenzanilides $\mathbf{1 0 2}$ into 6arylbenzimidazo[1,2-c] quinazolines 94 under microwave irradiation using $\mathrm{SiO}_{2}-\mathrm{MnO}_{2}(95: 5$ mixture) as solid inorganic support (Scheme 35). ${ }^{63}$

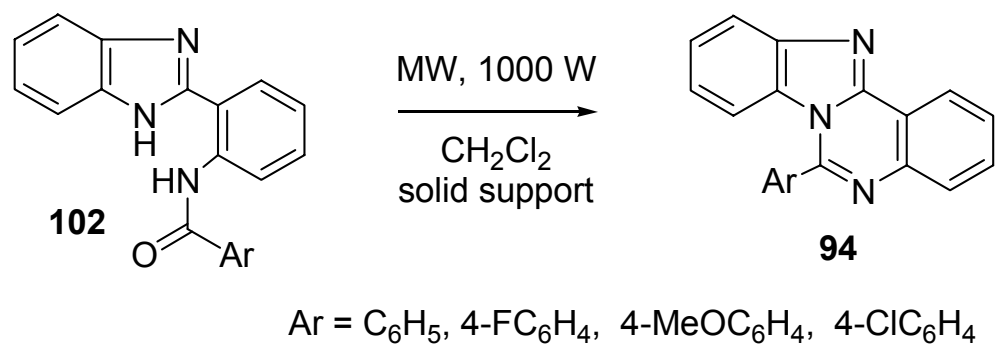

\section{Scheme 35}

Benzimidazo[1,2-c]quinazolines 103 was readily prepared in high yield by reduction of 2-(2nitrophenyl)benzimidazole $\mathbf{9 3}$ followed by reaction of the obtained 2-(2aminophenyl)benzimidazole 92 with aldehydes in ethanol/acetic acid mixture (Scheme 36). ${ }^{64}$<smiles>O=[N+]([O-])c1ccccc1-c1nc2ccccc2[nH]1</smiles>

93

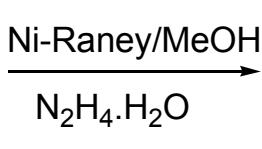

$\mathrm{N}_{2} \mathrm{H}_{4} \cdot \mathrm{H}_{2} \mathrm{O}$

(93)<smiles>Nc1ccccc1-c1nc2ccccc2[nH]1</smiles>

92<smiles>[R]OC(=O)OCC</smiles>

103

$\mathrm{R}=4-\mathrm{BrC}_{6} \mathrm{H}_{4}, 4-\mathrm{ClC}_{6} \mathrm{H}_{4}, 4-\mathrm{FC}_{6} \mathrm{H}_{4}, 4-\mathrm{OMeC}_{6} \mathrm{H}_{4}, 4-\mathrm{NO}_{2} \mathrm{C}_{6} \mathrm{H}_{4}, 3,4,5(\mathrm{OMe})_{3} \mathrm{C}_{6} \mathrm{H}_{2}$

\section{Scheme 36}


2-(o-Arylideneaminophenyl)benzimidazoles 104 were synthesized via the condensation between 2-(o-aminophenyl)benzimidazole 92 and various aldehydes in refluxing ethanol in the presence of catalytic amount of acetic acid. Oxidative cyclization of 2-(oarylideneaminophenyl)-benzimidazoles 104 using potassium permanganate in refluxing acetone resulted in the formation of 6-arylbenzimidazo[1,2-c] quinazolines 94 (Scheme 37) ${ }^{65}$<smiles>Nc1ccccc1-c1nc2ccccc2[nH]1</smiles>

92

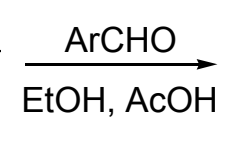<smiles>c1ccc(-c2nc3ccccc3[nH]2)c(N=[Ge]C2CCCCC2)c1</smiles>

$10465-80 \%$

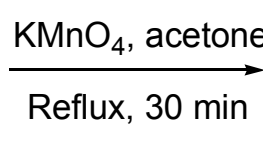

Reflux, 30 min<smiles>Brc1nc2ccccc2c2nc3ccccc3n12</smiles>

$94 \quad 67-81 \%$

$\mathrm{Ar}=$ phenyl, 2-pyridyl, 2-thienyl, 2-furyl

\section{Scheme 37}

Benzimidazo[1,2-c]quinazoline 106 derivative was prepared by the reaction of the benzoyl chloride derivative 105 with 2-(2-aminophenyl)benzimidazole 92 in acetic acid / acetic anhydride mixture (Scheme 38 ) ${ }^{66}$<smiles>O=C(Cl)c1cc([N+](=O)[O-])cc([N+](=O)[O-])c1Cl</smiles><smiles>Nc1ccccc1-c1nc2ccccc2[nH]1</smiles><smiles>[R]OC(=O)OCC(C)=O</smiles><smiles>O=[N+]([O-])c1cc(-c2nc3ccccc3c3nc4ccccc4n23)c(Cl)c([N+](=O)[O-])c1</smiles>

\section{Scheme 38}

Condensation of 2-(2-aminophenyl)benzimidazole 92 with 4-arylideneoxazolin-5-ones 107 in acetic acid resulted in the formation of the 6-arylidene-benzimidazo[1,2-c]quinazolines $\mathbf{1 0 8}$ (Scheme 39). ${ }^{67}$<smiles>Nc1ccccc1-c1nc2ccccc2[nH]1</smiles>

92<smiles>[R]C=C1N=C(C)OC1=O</smiles>

107<smiles>[R]C=C1Nc2ccccc2-c2nc3ccccc3n21</smiles>

$\mathrm{R}=\mathrm{Ph}, 4-\mathrm{MeC}_{6} \mathrm{H}_{4}, 4-\mathrm{ClC}_{6} \mathrm{H}_{4}, 3-\mathrm{NO}_{2} \mathrm{C}_{6} \mathrm{H}_{4}$

\section{Scheme 39}


Heating a mixture of 2-(2-aminophenyl)benzimidazole 92 and chloroacetylchloride in glacial acetic acid on water-bath at $60{ }^{\circ} \mathrm{C}$ gave 6-chloromethylbenzimidazo[1,2-c] quinazoline 109 in $68 \%$ yield (Scheme 40$){ }^{68}$

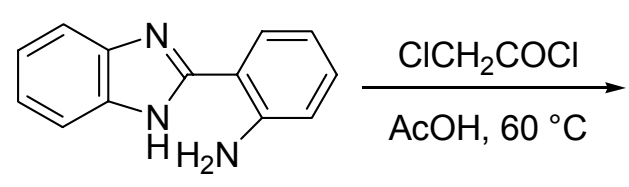

92<smiles>ClCc1nc2ccccc2c2nc3ccccc3n12</smiles>

$10968 \%$

\section{Scheme 40}

Reductive cyclization of 1-acetyl-2-(2-nitrophenyl)benzimidazole $\mathbf{1 1 0}$ in the presence of iron powder and $\mathrm{HCl}$ in refluxing ethanol produced benzimidazo[1,2-c]quinazoline $94(\mathrm{R}=\mathrm{Me})$ in $46 \%$ yield (Scheme 41$){ }^{69}$<smiles>CC(=O)n1c(-c2ccccc2N)nc2ccccc21</smiles>

110

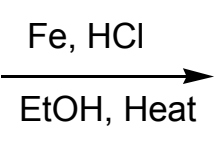<smiles>Cc1nc2ccccc2c2nc3ccccc3n12</smiles>

94

\section{Scheme 41}

2.2.8. Benzimidazo[1,2-b]cinnolines. The pyrolysis of arylhydrazonobenzotriazoles 111 resulted in the formation of the benzimidazo[1,2-b]cinnoline derivatives 116 via intramolecular nucleophilic addition involving the arylhydrazono group and the ketone carbonyl moiety followed by cyclization and subsequent elimination of $\mathrm{H}_{2} \mathrm{O}$ and $\mathrm{N}_{2}$ from the intermediates 112115 according to the mechanism outlined in Scheme 42. ${ }^{70}$ 


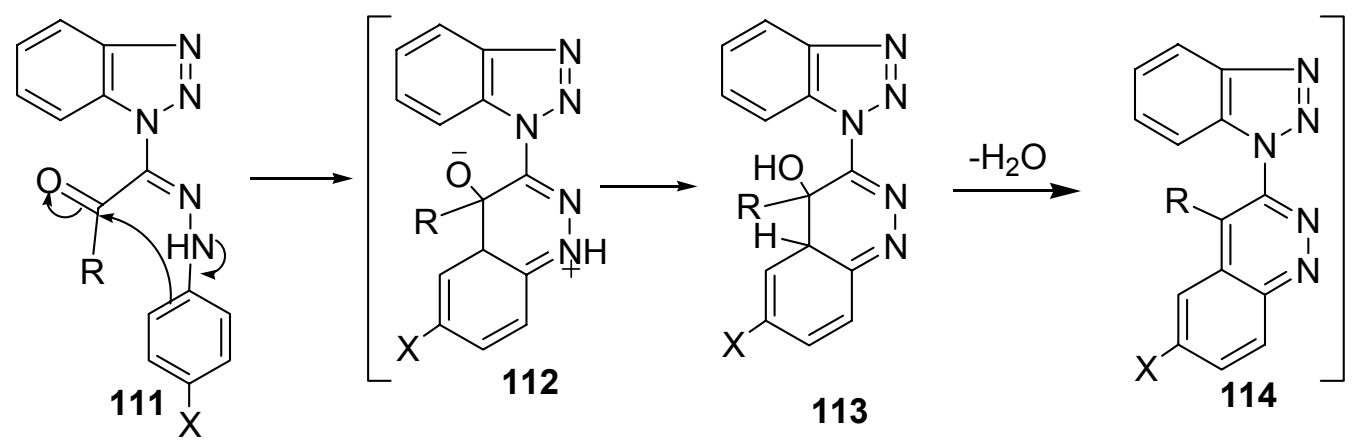<smiles>[X]c1ccc2nn3c(nc4cc(CC)ccc43)c([R])c2c1</smiles>

$\mathrm{R}=\mathrm{Me}, \mathrm{Ph} \quad \mathrm{X}=\mathrm{H}, \mathrm{OCH}_{3}, \mathrm{CH}_{3}, \mathrm{Cl}$

\section{Scheme 42}

2.2.9. Pyridopyridobenzimidazoles. Reaction of 2-chloronicotinoyl chloride 117 with 2benzimidazoleacetonitrile 42 gave the conjugated nitrile 118 in 97\% yield, which was then cyclized on heating to give the corresponding fused tetraheterocyclic system 119 in high yield (Scheme 43). ${ }^{71}$

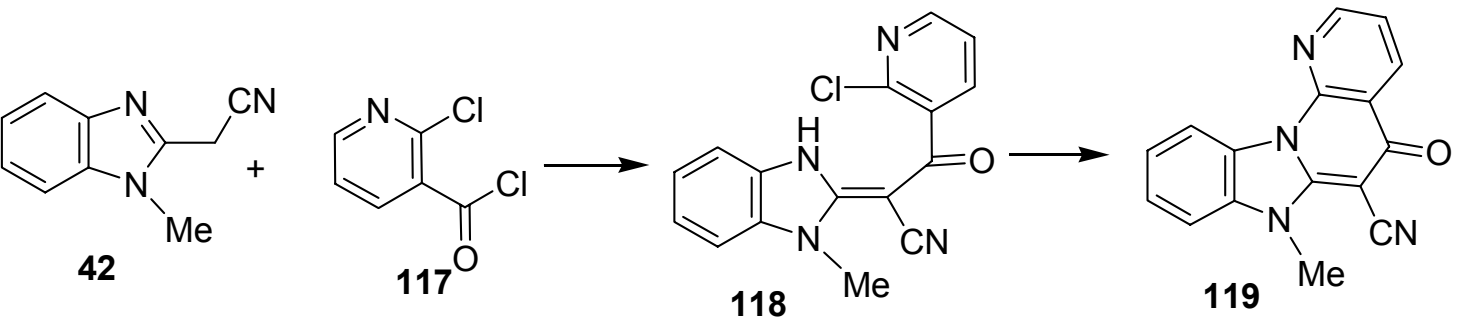

\section{Scheme 43}

2.2.10. Fused macroheterocycles with three heteroatoms. The synthesis of $5 H$ benzimidazo[1,2- $d]$-1,4-benzodiazepin-6(7H)-ones 121 was readily accomplished by reaction of 2-(2-aminophenyl)-1H-benzimidazole derivatives 92 and 2-bromoacetyl bromide via the intermediate 120, under microwave irradiation conditions at $300 \mathrm{~W}$ in THF and sodium carbonate (Scheme 44). ${ }^{72}$ 
<smiles></smiles>

92<smiles></smiles>

120
$12150-75 \%$

$\mathrm{R}^{1}, \mathrm{R}^{2}: \mathrm{H}, \mathrm{Me}, \mathrm{F}, \mathrm{Cl}, \mathrm{Br}$

\section{Scheme 44}

2.2.11. Benzimidazo[2,1-b]benzoxazoles. Benzimidazo[2,1-b]benzoxazole 123 was prepared photolytically at $360 \mathrm{~nm}$ from 1-(2-benzoxazolyl)benzotriazole 122 (Scheme 45). ${ }^{73}$<smiles>c1ccc2oc(-n3nnc4ccccc43)nc2c1</smiles>

122

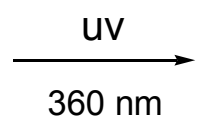

$360 \mathrm{~nm}$<smiles>c1ccc2c(c1)nc1oc3ccccc3n12</smiles>

123

\section{Scheme 45}

\subsection{With four heteroatoms}

2.3.1. Pyrazolo[3,4:4 , 3’ $]$ pyrrolo[1,2-a]benzimidazoles. Treatment of hydrazonoyl chlorides 124 with 2-cyanomethylbenzimidazol 42 in ethanolic sodium ethoxide solution at room temperature afforded ethyl 5-amino-1-aryl-4-(benzimidazol-2-yl)pyrazole-3-carboxylate $\mathbf{1 2 5}$. Heating $\mathbf{1 2 5}$ in chloroform in the presence of triethylamine yielded 1-amino-2arylpyrazolo[3,4:4' , 3']pyrrolo[1,2-a] benzimidazoles 126 via loss of ethanol (Scheme 46). ${ }^{74}$

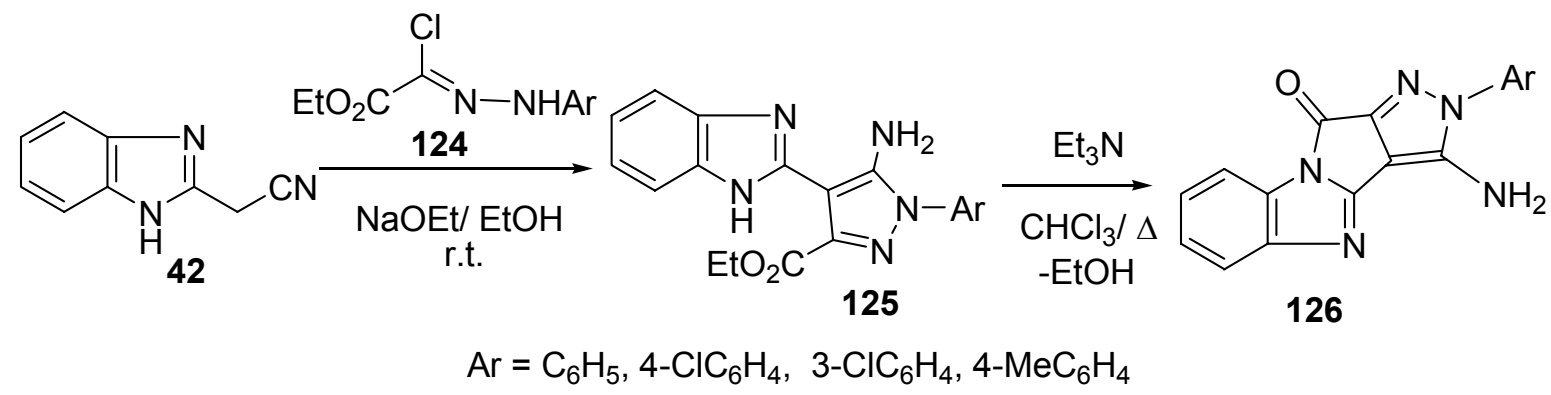

\section{Scheme 46}


Condensation of pyrazolylbenzimidazoles $\mathbf{1 2 7}$ with dimethylformamide-dimethylacetal (DMF-DMA) at $100 \sim 105{ }^{\circ} \mathrm{C}$ led to the formation of pyrazolo[3,4:3',4]pyrrolo[1,2a] benzimidazole derivatives $\mathbf{1 2 8}$ in $80 \%$ yield (Scheme 47 ). ${ }^{75}$

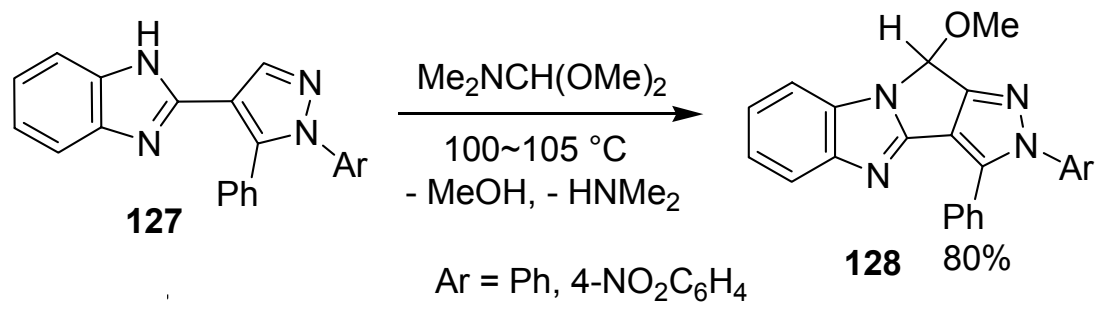

\section{Scheme 47}

Refluxing the benzimidazole-2-Eschenmoser hydrazone 129 in benzene for three hours gave $3,3 a, 4,10 b$-tetrahydropyrazolo[3',4':3,4]pyrrolo[1,2-a]benzimidazole $\mathbf{1 3 0}$ in $56 \%$ yield via the 1,3-dipolar intramolecular [3+2] cycloaddition with thermal cleavage of $\mathbf{1 2 9}$ to generate transstilbene (Scheme 48). ${ }^{76}$

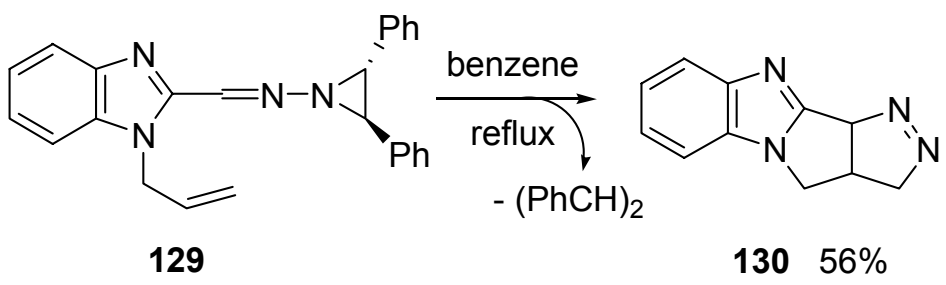

\section{Scheme 48}

2.3.2. Pyridazino-pyrrolo-benzimidazoles. Treatment of 4,5-dichloropyridazine 1312 cyanomethylbenzimidazoles $\mathbf{4 2}$ in the presence of potassium carbonate led to the formation of pyridazino-pyrrolo-benzimidazoles $\mathbf{1 3 3}$ via loss of $\mathrm{HCl}$ from the intermediate $\mathbf{1 3 2}$ (Scheme $49) .^{77}$

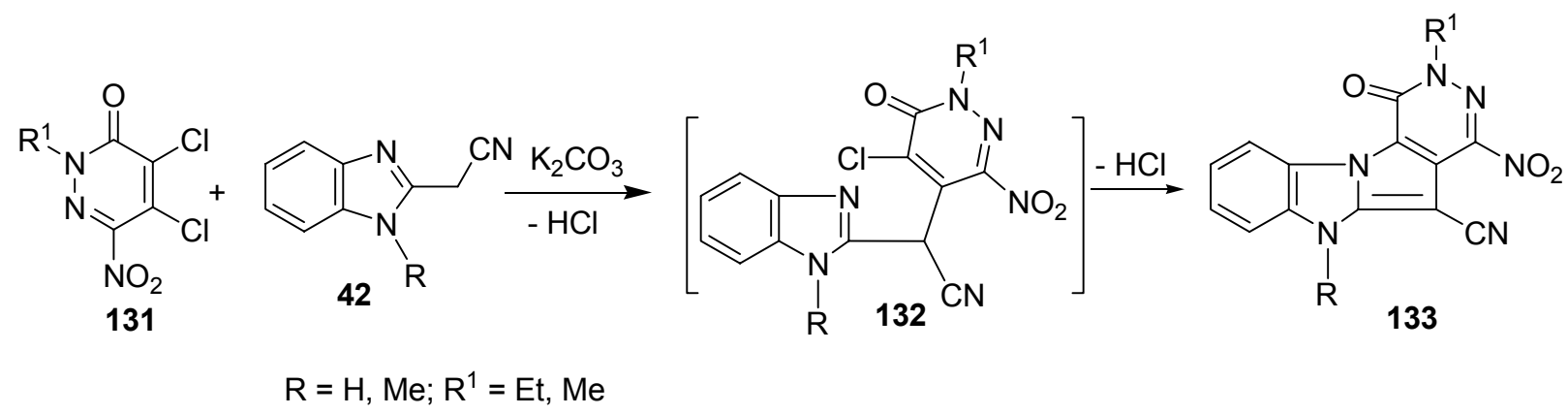

Scheme 49 
Treatment of 2-aminobenzimidazoles 134 with 2-chloronicotinic acid 135 in DMF, in the presence of $\mathrm{K}_{2} \mathrm{CO}_{3}$, gave the amides 136 which upon reflux in benzene and pyridine afforded the 5-oxopyrido[3',2 ':5,6]pyrimido[1,2-a]benzimidazoles 137 (Scheme 50). ${ }^{78,79}$<smiles>[R]n1c(N)nc2ccccc21</smiles>

\section{Scheme 50}

2.3.3. Pyrazolo[4.3:5,6]pyrido[1,2-a]benzimidazoles. The condensation of 5-chloro-4formylpyrazoles 138 with 2-benzimidazoleacetonitrile $\mathbf{4 2}$ in pyridine-DMF mixture led to the pyrazolo[4.3:5,6]pyrido[1,2-a]benzimidazoles 139 in high yields (Scheme 51). ${ }^{80,81}$

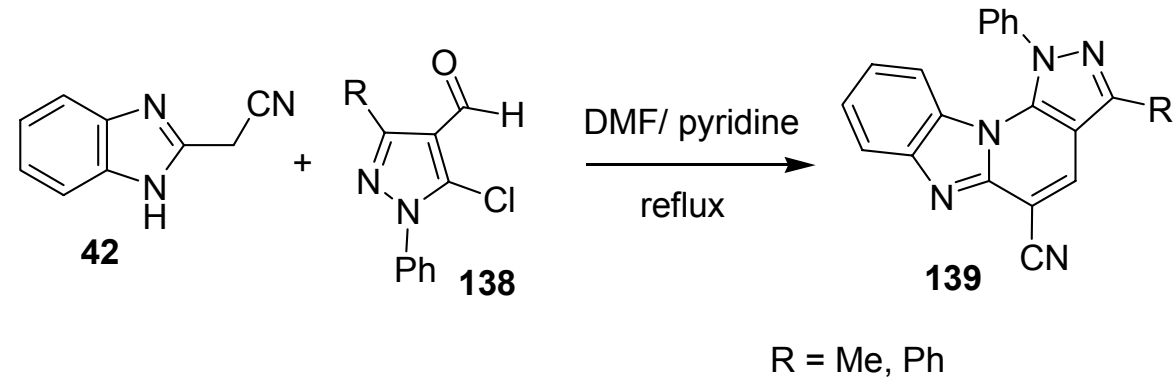

\section{Scheme 51}

Pyrazolo[4',3':5,6]pyrido[1,2-a]benzimidazoles 141 were prepared by the condensation of pyridobenzimidazoles 140 with hydrazines (Scheme 52). ${ }^{82}$<smiles>[R]c1c(C)c(C#N)c2nc3ccccc3n2c1Cl</smiles>

140<smiles>[R]c1nn([R])c2c1c(C)c(C#N)c1nc3ccccc3n12</smiles>

141

$$
\mathrm{R}=\mathrm{CHO}, \mathrm{CN} \quad \mathrm{R}^{1}=\mathrm{H}, \mathrm{NH}_{2} ; \mathrm{R}^{2}=\mathrm{H}, \mathrm{Ph}
$$

\section{Scheme 52}


2.3.4. Imidazo $\left[4^{\prime}, 5^{\prime}: 5,6\right]$ pyrido $[1,2-a]$ benzimidazoles. Heating a mixture of the diaminopyridobenzimidazole $\mathbf{1 4 2}$ and formic acid in the presence of aq. $\mathrm{HCl}$ at reflux condition followed by neutralization with $\mathrm{Et}_{3} \mathrm{~N}$ gave $60 \%$ yield of $1 H$-imidazo[4',5':5,6]pyrido[1,2a]benzimidazoles 143 (Scheme 53). ${ }^{83}$<smiles>Nc1ccc2nc3ccccc3n2c1N</smiles>

142
1) $\mathrm{HCO}_{2} \mathrm{H}, \mathrm{HCl}$, reflux

2) $\mathrm{Et}_{3} \mathrm{~N}$<smiles>c1ccc2c(c1)nc1ccc3nc[nH]c3n12</smiles>

$14360 \%$

\section{Scheme 53}

2.3.5. Oxazolo[4',5':5,6]pyrido[1,2-a]benzimidazoles. The condensation of 2-amino-1hydroxypyrido[1,2-a]benzimidazole 144 with acetic anhydride at reflux yielded 2,4dimethyloxazolo[4',5':5,6]pyrido[1,2-a]benzimidazole 145 which was used as fluorescent brighteners for polyester fibers (Scheme 54). ${ }^{84}$
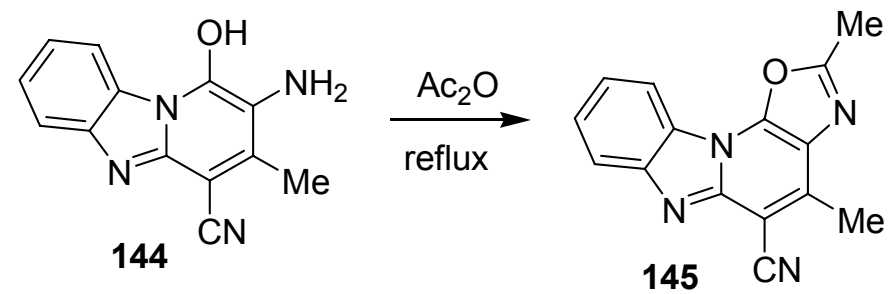

\section{Scheme 54}

2.3.6. Pyrimido-pyrido-benzimidazoles. Treatment of 2 -benzimidazoleacetonitrile 42 with arylidenemalononitrile $\mathbf{1 4 6}$ in ethanol containing piperidine gave 1-aminopyrido[1,2a]benzimidazole-2,4-dicarbonitriles 147 which upon heating with dimethylformamidedimethylacetal (DMF-DMA) in dioxane gave the corresponding $N, N$ (dimethylaminomethylene)amino derivatives 148. Condensation of 148 with hydrazine hydrate in ethanol at room temperature afforded 3-amino-4-imino-5-aryl-6cyanopyrimido[5 $\left.5^{`} 4^{`}: 5,6\right]$ pyrido[1,2-a] benzimidazoles 149 (Scheme 55). ${ }^{85}$ 


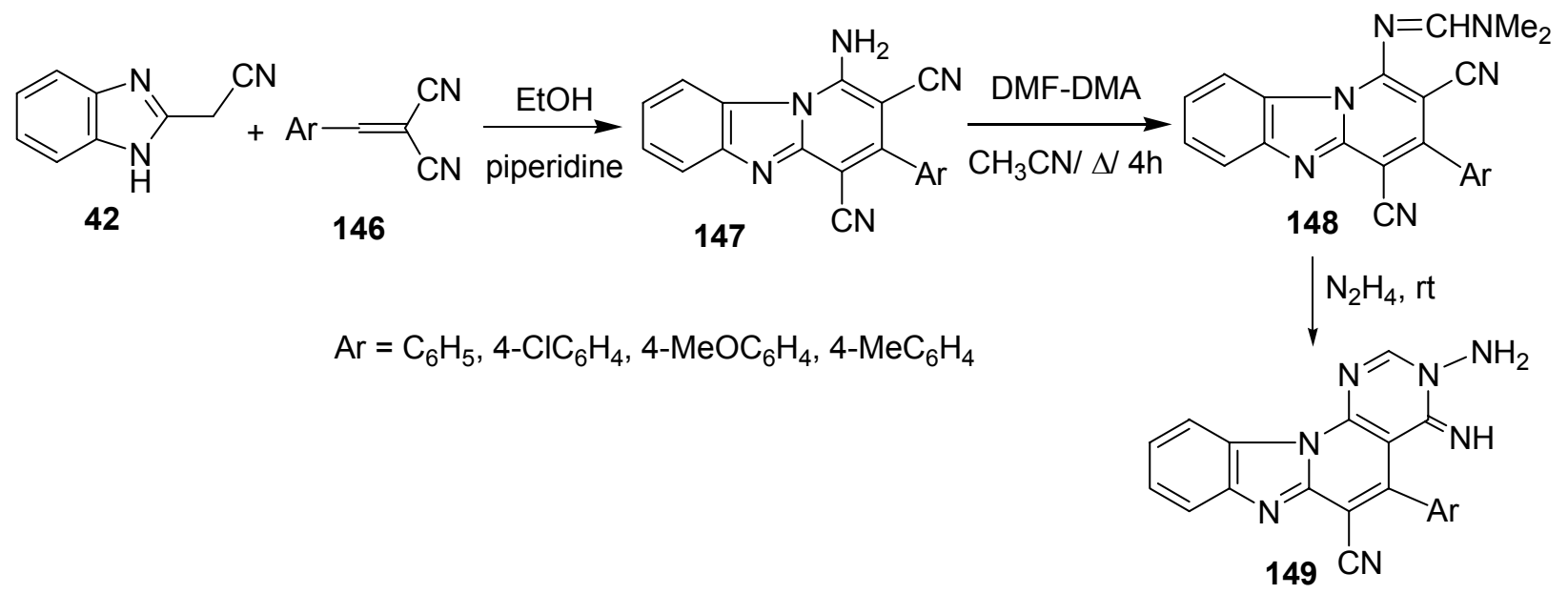

\section{Scheme 55}

1-Aminopyrido[1,2-a] benzomidazole-2,4-dicarbonitriles 147 underwent cyclocondensation reaction when heated with formamide to yield the pyrimido[5',4':5,6]pyrido[1,2a]benzimidazoles $\mathbf{1 5 0}$ in $83-93 \%$ yields (Scheme 56). ${ }^{86,87}$<smiles>[X]C(N)=O</smiles>

147<smiles>N#Cc1c(Br)c2c(N)ncnc2n2c1nc1ccccc12</smiles>

$15083-93 \%$

$\mathrm{Ar}=\mathrm{Ph}, 4-\mathrm{ClC}_{6} \mathrm{H}_{4}, 4-\mathrm{MeOC}_{6} \mathrm{H}_{4}, 4-\mathrm{MeC}_{6} \mathrm{H}_{4}$

\section{Scheme 56}

Reaction of 2-cyanomethylbenzimidazoles 42 with ethyl 4-chloro-2-methylthio-5pyrimidine-carboxylate 151 in refluxing DMF in the presence of $\mathrm{K}_{2} \mathrm{CO}_{3}$ led to the formation of the 3-methylthio-5-cyano-12-oxopyrimido[4',5'-4,5]pyrido[1,2-a]benzimidazoles 152 in 85-88\% yields via the intermediate 152 (Scheme 57). ${ }^{88}$

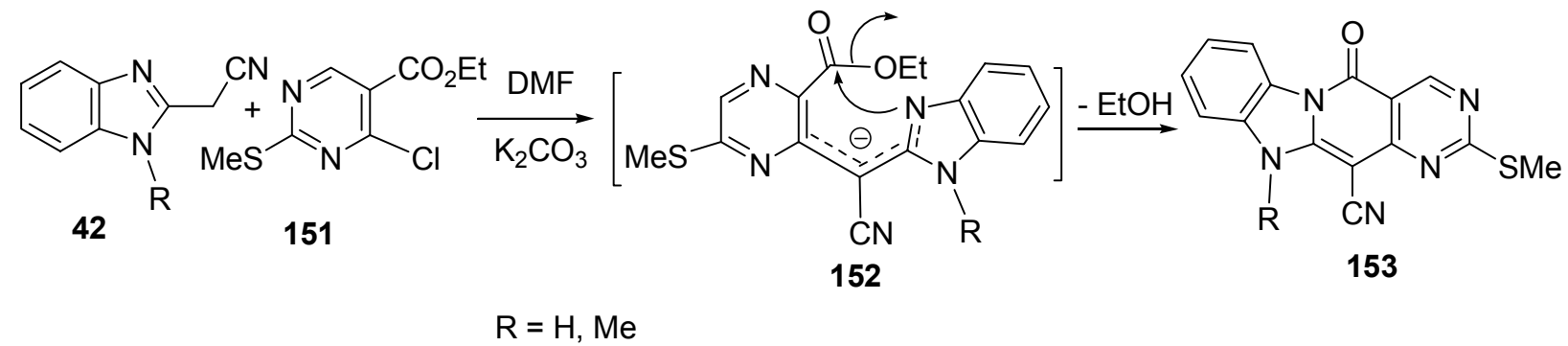

Scheme 57 
7-Methyl-3-(methylthio)-5-oxo-6-cyanopyrimido[4',5':5,6]pyrido[1,2-a]benzimidazole 156 was prepared from the reaction of 2-benzimidazoleacetonitrile 42 with 4-bromo-2methylsulfanyl-5-pyrimidinoyl chloride $\mathbf{1 5 4}$ in the presence of $N, N$-dimethylbenzylamine followed by intramolecular cyclization of the intermediate 155 (Scheme 58). ${ }^{89}$

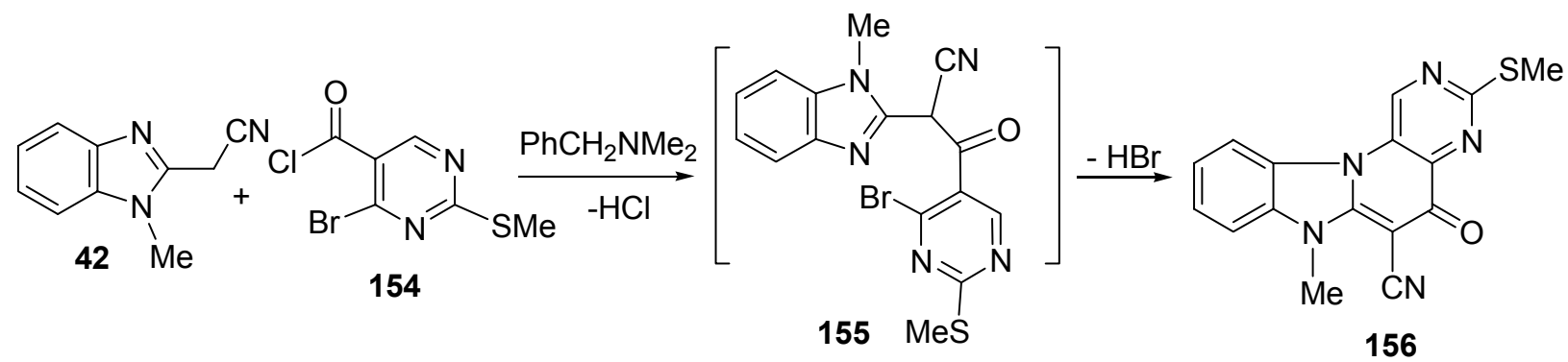

\section{Scheme 58}

2.3.7. Pyrido-pyrimido-benzimidazoles. 2-Aminonicotinic acid 157 reacted with aromatic acid chlorides in pyridine to give 2-arylpyrido[2,3- $d]$ [1,3] oxazin-4-ones $\mathbf{1 5 8}$. Treatment of the latter compounds $\mathbf{1 5 8}$ with $o$-phenylenediamines 1 in pyridine gave the 6arylpyrido[2',3':4,5]pyrimido[1,6- $a$ ] benzimidazoles 159 (Scheme 59). ${ }^{90}$<smiles>Nc1ncccc1C(=O)O</smiles>

157<smiles>O=c1oc(Br)nc2ncccc12</smiles>

158

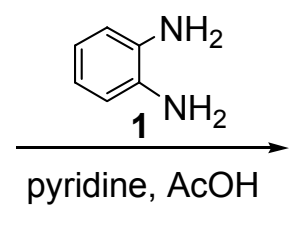

$\mathrm{Ar}=\mathrm{Ph}, 4-\mathrm{MeC}_{6} \mathrm{H}_{4}, 4-\mathrm{ClC}_{6} \mathrm{H}_{4}, 4-\mathrm{NO}_{2} \mathrm{C}_{6} \mathrm{H}_{4}$

\section{Scheme 59}

Compounds 159 were alternatively accomplished by refluxing 2-(2-amino-3pyridyl)benzimidazole $\mathbf{1 6 0}$ with aromatic aldehydes in acetic acid to give 5,6dihydropyridopyrimidobenzimidazoles 161. Oxidation of the latter compounds 161 with $\mathrm{KMnO}_{4}$ in acetone afforded 6-arylpyrido[2',3':4,5]pyrimido[1,6- $a$ ]benzimidazoles $\mathbf{1 5 9}$ (Scheme 60). ${ }^{91}$ 


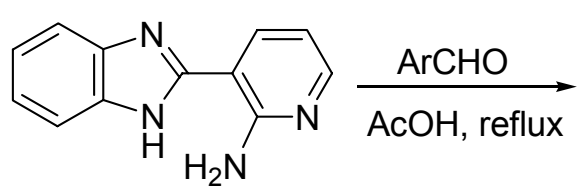

160<smiles>[C]C1Nc2ncccc2-c2nc3ccccc3n21</smiles>

161<smiles>COC(OC)C(OC)OC</smiles>

159

$\mathrm{Ar}=\mathrm{Ph}, 4-\mathrm{MeOC}_{6} \mathrm{H}_{4}, 4-\mathrm{MeC}_{6} \mathrm{H}_{4}, 4-\mathrm{ClC}_{6} \mathrm{H}_{4}, 4-\mathrm{BrC}_{6} \mathrm{H}_{4}, 4-\mathrm{O}_{2} \mathrm{NC}_{6} \mathrm{H}_{4}$, 2-thienyl

\section{Scheme 60}

2.3.8. Thieno[2',3:3,4]pyrimido[1,6-a]benzimidazoles. Reaction of 1-ethoxycarbonyl-2benzimidazoleacetonitrile $\mathbf{1 6 2}$ with phenylisothiocyanate in DMF in the presence of $\mathrm{KOH}$ gave 4-cyano-3-mercaptopyrimido[1,6-a]benzimidazole 163. Treatment of 163 with chloroacetone in DMF and potassium hydroxide at room temperature yielded 2-acetyl-3-amino-10-oxo-11phenylthieno[2 $\left.23^{\prime}: 4,5\right]$ pyrimido[1,6- $\left.a\right]$ benzimidazole 164 (Scheme 61). ${ }^{92}$<smiles>CCOC(=O)n1c(CC#N)nc2ccccc21</smiles>

162<smiles>CC(=O)CC(C)(C)C(C)(C)C(=O)O</smiles>

163<smiles>CC(C)(C)Nc1sc2c3ccccc3nc-2c2c1C(=O)N(c1ccccc1)C2=O</smiles>

\section{Scheme 61}

2.3.9. Pyrido[2,3 $: 4,5]$ thiazolo $[2,3-a]$ benzimidazoles. Heating a mixture of 2 mercaptobenzimidazole 90 with chloroacetic acid in the presence of acetic anhydride gave 4oxo-3,4-dihydro-5H-thiazolo[2,3-a]benzimidazole $\mathbf{1 6 5}$. Treatment of $\mathbf{1 6 5}$ with aromatic aldehydes, malononitrile and ammonium acetate in refluxing DMF yielded 2-amino-3-cyano-4arylpyrido[2 $\left.3^{\prime}: 4,5\right]$ thiazolo[2,3-a] benzimidazoles 166 in reasonable yields (Scheme 62). ${ }^{93}$<smiles>Sc1nc2ccccc2[nH]1</smiles>

90

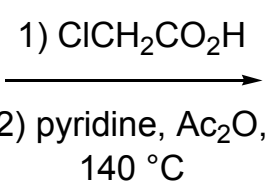
$140^{\circ} \mathrm{C}$<smiles></smiles>

165

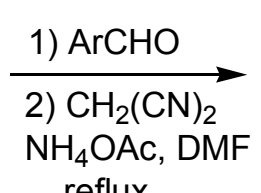

reflux<smiles>N#Cc1c(N)nc2c(sc3nc4ccccc4n32)c1Br</smiles>

166

$$
\mathrm{Ar}=\mathrm{Ph}, 4-\mathrm{MeOC}_{6} \mathrm{H}_{4}, 4-\mathrm{MeC}_{6} \mathrm{H}_{4}, 4-\mathrm{ClC}_{6} \mathrm{H}_{4}, 4-\mathrm{HOC}_{6} \mathrm{H}_{4}, 3-\mathrm{O}_{2} \mathrm{NC}_{6} \mathrm{H}_{4}
$$

\section{Scheme 62}


2.3.10. Azeto[3',2':4,5]pyrazolo[1,5-a]benzimidazoles. Treatment of 2-alkyl-3H$[1,2,4]$ triazepino[2,3-a]benzimidazol-4-one $\mathbf{1 6 7}$ with acetic anhydride gave 3-alkyl-10-acetyl4H-azeto[3',2':4,5]pyrazolo[1,5- $a$ ] benzimidazol-2-ones $\mathbf{1 6 9}$ in low yields via ring contraction ionic mechanism of the intermediate $\mathbf{1 6 8}$ as shown in Scheme $63 .{ }^{94}$

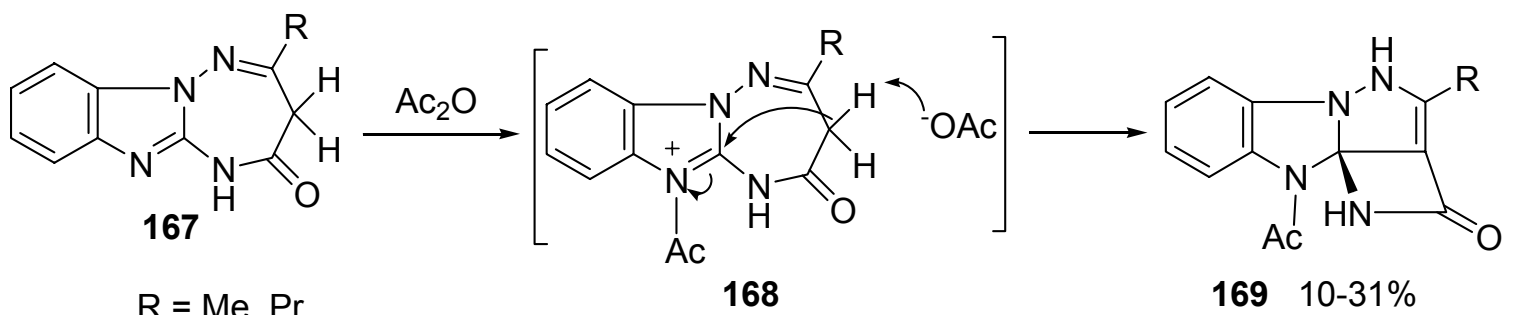

\section{Scheme 63}

2.3.11. Fused macroheterocycles with four heteroatoms. Cycloalkano-1,2,4-triazepino[2,3a]benzimidazolones 171 were prepared in low yields by condensing 1,2-diaminobenzimidazole 170 with 5 equivalents of ethyl cycloalkanone-2-carboxylates 45 at reflux temperature (Scheme 64). ${ }^{95}$

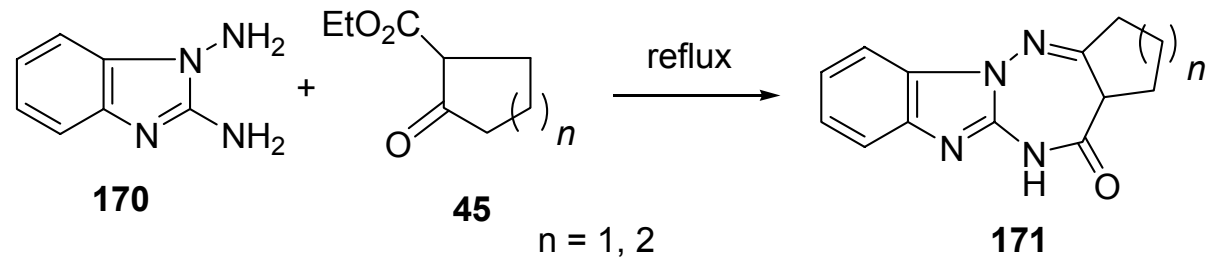

\section{Scheme 64}

\subsection{With five heteroatoms}

2.4.1. 1,3-Thiazolo[4',5':4,5]pyrimido[1,6-a]benzimidazoles. Reaction of 2benzimidazoleacetonitrile $\mathbf{4 2}$ with arylisothiocyanates in the presence of elemental sulfur and $\mathrm{Et}_{3} \mathrm{~N}$ in $\mathrm{DMF}$ at room temperature gave moderate yields of the thiazolylbenzimidazole derivatives 172. Treatment of the latter compounds with carbon disulfide in DMF under reflux followed by $S$-alkylation afforded the thiazolo[4',5':4,5]pyrimido[1,6-a]benzimidazole-2(3H)thiones $\mathbf{1 7 3}$ in 50-65\% yields (Scheme 65). ${ }^{96,97}$ 
<smiles>N#CCc1nc2ccccc2[nH]1</smiles>

42

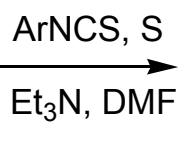

$\mathrm{Et}_{3} \mathrm{~N}, \mathrm{DMF}$

172<smiles>Nc1c(-c2nc3ccccc3[nH]2)sc(=S)n1[Al]</smiles>

$\underset{\text { 2) } \mathrm{RI}, \mathrm{DMF}}{\stackrel{\text { 1) } \mathrm{CS}_{2}, \mathrm{Et}_{3} \mathrm{~N}}{\longrightarrow}}$

$\mathrm{R}=\mathrm{Me}, \mathrm{CH}_{2} \mathrm{CO}_{2} \mathrm{Et}$

\section{Scheme 65}

2.4.2. Pyrimido[4, 5: 4,5$]$ thiazolo[2,3-a]benzimidazoles. When 3-aminothiazolo[3,2a]benzimidazole-2-carbonitrile $\mathbf{1 7 4}$ was treated with formamide and with acetic anhydride at 100 ${ }^{\circ} \mathrm{C}$ it gave the tetracyclic; pyrimido[4',5:4,5]thiazolo[2,3-a]benzimidazoles 175 and 176, respectively (Scheme 66) ${ }^{98,99}$ When the thiazolo[3,2-a]benzimidazole 174 was allowed to react with carbon disulphide followed with alkyl iodides in $\mathrm{EtOH}$ and $\mathrm{KOH}$ it gave the corresponding dialkylthio derivatives of pyrimido[4 $, 5 ` 4,5]$ thiazolo[2,3-a]benzimidazole 177 (Scheme 66). ${ }^{100}$<smiles>Cc1nc2c(sc3nc4ccccc4n32)c(=O)[nH]1</smiles>

176

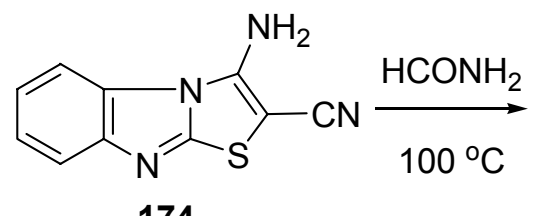

174<smiles>Nc1ncnc2c1sc1nc3ccccc3n12</smiles>

175

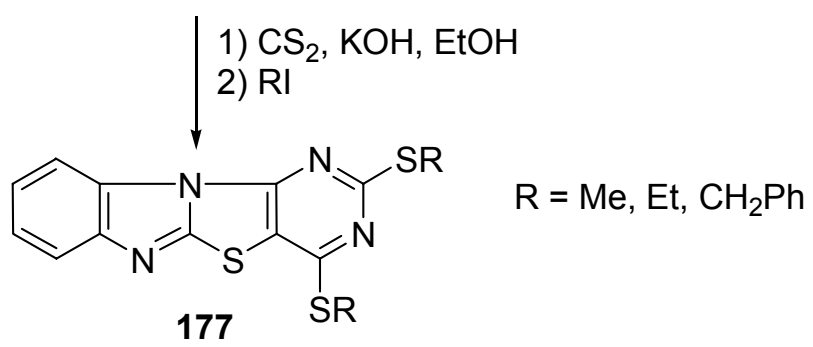

\section{Scheme 66}

Reaction of 3-aminothiazolo[3,2-a]benzimidazole-2-carboxamide $\mathbf{1 7 8}$ with aromatic carboxylic acids or with their chlorides afforded the corresponding pyrimido-fused derivatives 179 (Scheme 67). ${ }^{101}$<smiles>NC(=O)c1sc2nc3ccccc3n2c1N</smiles>

178

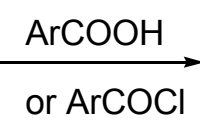<smiles>O=c1[nH]c(Br)nc2c1sc1nc3ccccc3n12</smiles>

$$
\mathrm{Ar}=\mathrm{Ph}, 4-\mathrm{MeOC}_{6} \mathrm{H}_{4}
$$

\section{Scheme 67}


2.4.3. Triazolo[4,5-b]pyrido[1',2 $-a]$ benzimidazoles. Condensation of 2-(arylhydrazono)-3iminobutanenitrile $\mathbf{1 8 0}$ with 2-benzimidazoleacetonitrile $\mathbf{4 2}$ in acetic acid furnished the corresponding 3-methylpyrido[1,2-a] benzimidazoles 181. Treatment of compounds 181 with cupric acetate in DMF resulted in their oxidative cyclization to give the $S$-triazolo[4,5b]pyrido[1 ' $2^{`}$ - $a$ ] benzimidazoles 182 (Scheme 68). ${ }^{102}$

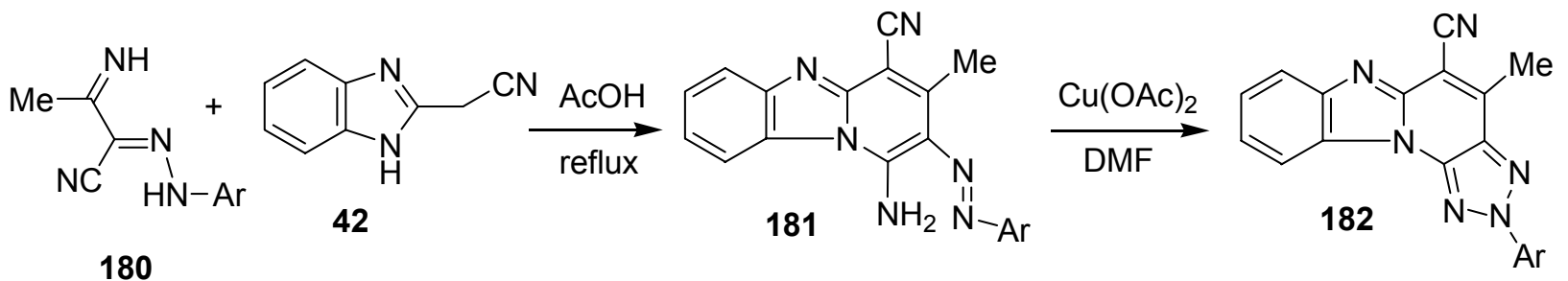

\section{Scheme 68}

2.4.4. Pyrazolo[3',4':4,5]pyrimido[1,6-a]benzimidazoles. Reaction of 4-(2-benzimidazolyl)-1methyl-5-aminopyrazole $\mathbf{1 8 3}$ with trialkylorthoformates in refluxing butanol gave the pyrazolo[3',4':4,5]pyrimido[1,6-a]benzimidazole derivatives 184 in good yields (Scheme 69). ${ }^{103}$

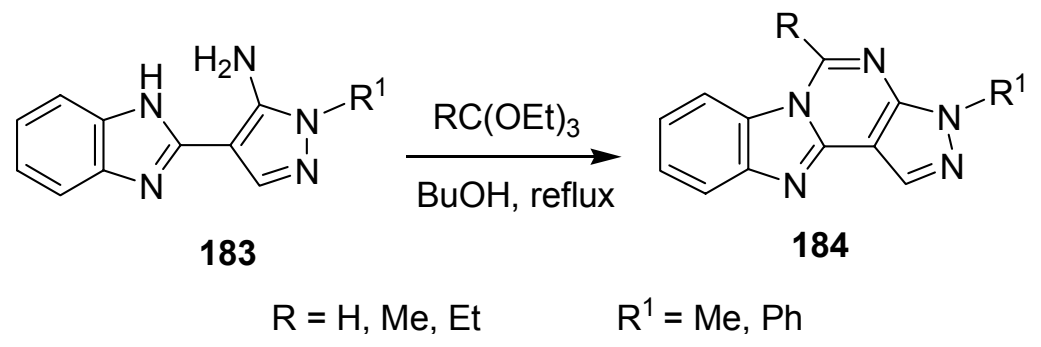

\section{Scheme 69}

2.4.5. 1,3,4-Oxadiazolo $\left[2^{\prime}, 3^{\prime}: 2,3\right]$ pyrimido $[1,6-a]$ benzimidazoles. The 1,3,4oxadiazolo[2',3':2,3]pyrimido[1,6-a]benzimidazoles 187 were prepared by treatment of 2acetonyl-1 $H$-benzimidazolehydrazones $\mathbf{1 8 5}$ with trifluoroacetic anhydride in dioxane at room temperature via loss of water from the intermediate 186 (Scheme 70). ${ }^{104}$ 


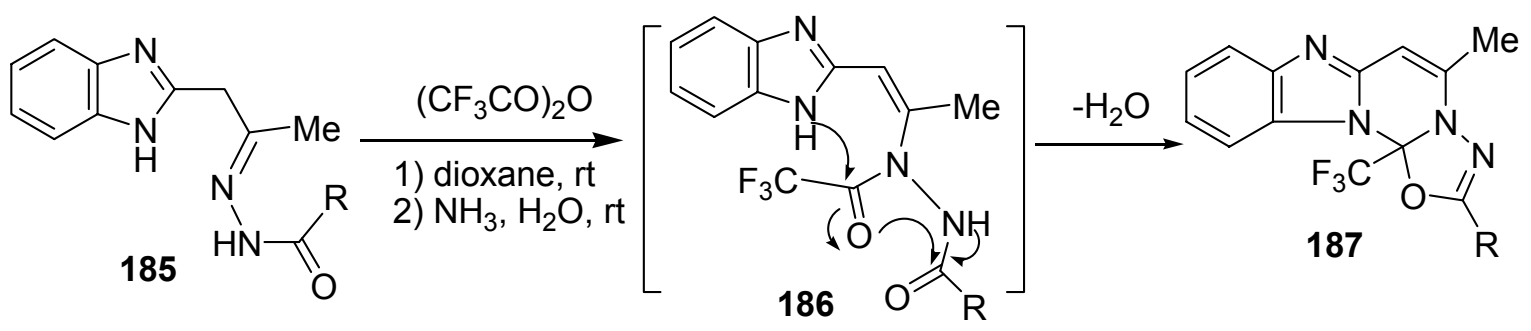

$\mathrm{R}=\mathrm{Ph}, 4-\mathrm{MeOC}_{6} \mathrm{H}_{4}, 4-\mathrm{O}_{2} \mathrm{NC}_{6} \mathrm{H}_{4}$, 2-thienyl, 4-pyridyl

\section{Scheme 70}

2.4.6. Pyrimido $\left[4^{\prime}, 5^{\prime}: 4,5\right]$ pyrimido $[1,2-a]$ benzimidazole. Intramolecular cyclocondensation of pyrimidobenzimidazolylurea derivatives 188 under the action of $\mathrm{K}_{2} \mathrm{CO}_{3}$ in refluxing DMF gave the pyrimido[4',5':4,5]pyrimido[1,2-a]benzimidazole derivatives 189 in good yields (Scheme 71). ${ }^{105}$

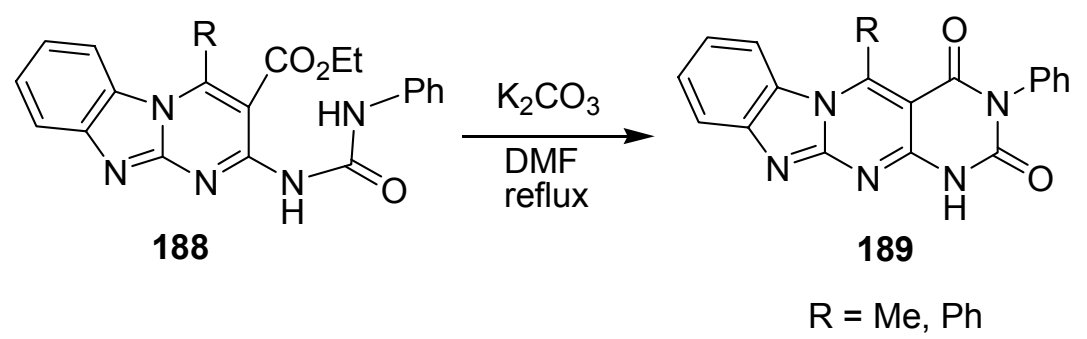

\section{Scheme 71}

2.4.7. Pyridazino-pyrimido-benzimidazoles. Reaction of 2-benzimidazoleacetonitrile 42 with arylhydrazones 190 gave the benzimidazolylpyridazines 191 in 90-99\%, which were cyclized by acyl chlorides or anhydrides to give 80-94\% of the pyridazinopyrimidobenzimidazoles 192 (Scheme 72). ${ }^{106}$

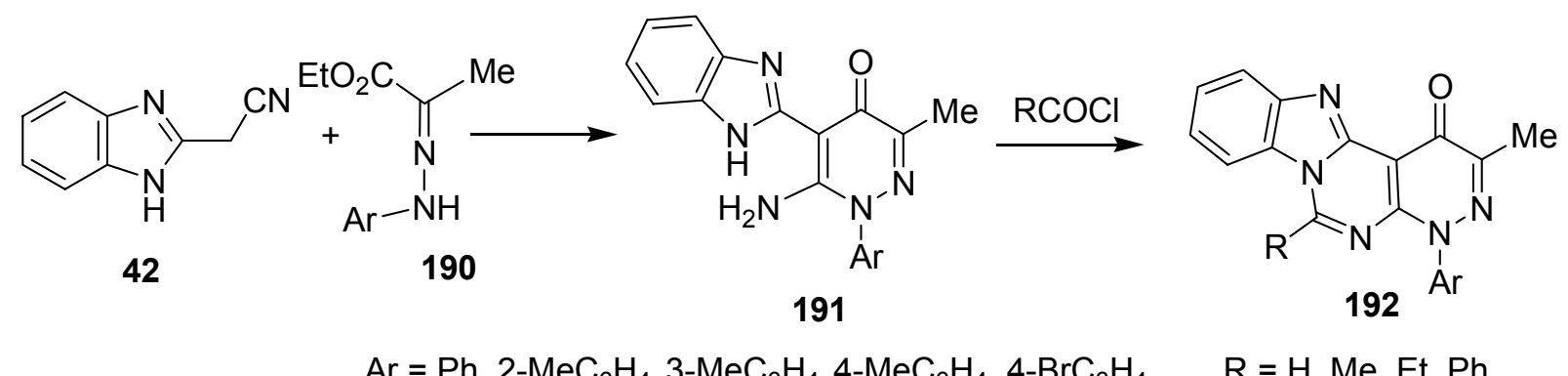

Scheme 72 
2.4.8. Benzimidazo $\left[2^{\prime}, \mathbf{1}^{\prime}: \mathbf{2 , 3},[\mathbf{1 , 3}\right.$, thiazino[6,5-d $]$ pyrimidine. Synthesis of $5 H$ benzimidazo[2', $\left.1^{\prime}: 2,3\right][1,3]$ thiazino[6,5- $\left.d\right]$ pyrimidine 194 was reported via the cyclocondensation between 2-methylthiopyrimidine-5-carboxaldehyde 193 and 2-mercaptobenzimidazole 90 in DMF at $30-50{ }^{\circ} \mathrm{C}$ (Scheme 73$) .{ }^{107}$<smiles>Sc1nc2ccccc2[nH]1</smiles>

90<smiles>CSc1nc(Cl)c(C=O)c(Cl)n1</smiles>

193

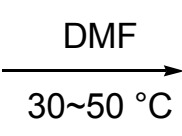<smiles>CSc1nc(Cl)c2c(n1)Sc1nc3ccccc3n1C2O</smiles>

$19471 \%$

\section{Scheme 73}

2.4.9. Thiadiazino $[3 ` 4 ` 5,4]$ pyrrolo[1,2-a]benzimidazole. Reaction of (3,5-dichloro-4H-1,2,6thiadiazin-4-ylidene)propanedinitrile 195 with 1,2-diaminobenzene 1 in ethanol at $20{ }^{\circ} \mathrm{C}$ gave 4chloro-5-cyano-1,2,6-thiadiazino[3 '4`: 5,4]pyrrolo[1,2-a]benzimidazole 198 via loss of $\mathrm{HCl}$ and $\mathrm{NH}_{3}$ molecules as shown in Scheme 74 . $^{108}$

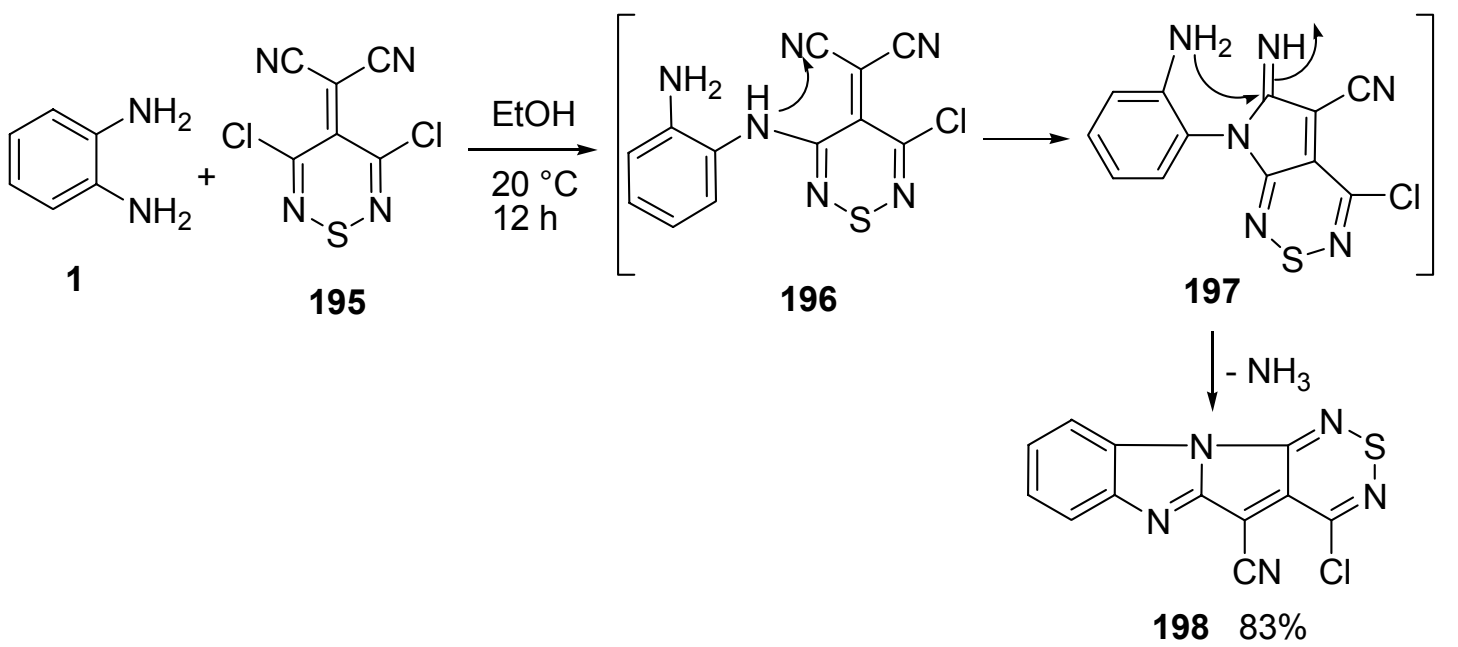

\section{Scheme 74}

2.4.10. Fused macroheterocycles with five heteroatoms. Reaction of the 1,3-diazepino[3,4a] benzimidazole-2-thione $\mathbf{1 9 9}$ with acid hydrazides $\mathbf{2 0 0}$ in refluxing butanol gave the tetracyclic triazolo-diazepino-benzimidazole derivatives 201 (Scheme 75). ${ }^{109}$ 


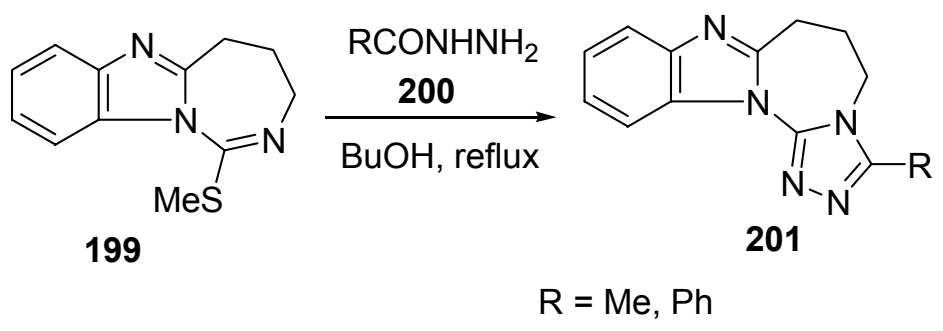

\section{Scheme 75}

Treatment of the pyrazoles 202 with cyanogen bromide afforded the 2-amino-1-(5 pyrazolyl)benzimidazoles 203 which upon treatment with 1,2-dibromoethane in the presence of 18-crown-6 in DMF and $\mathrm{K}_{2} \mathrm{CO}_{3}$ gave the pyrazolo[2,3-a]triazepino[3,2-a]benzimidazoles 204 (Scheme 76). ${ }^{110}$<smiles>[R]c1cc(N)c(Nc2cc(-c3ccccc3)n[nH]2)cc1[R]</smiles>

202<smiles>[R]c1cc2nc(N)n(-c3cc(-c4ccccc4)n[nH]3)c2cc1[R]</smiles>

$\mathrm{R}=\mathrm{H}$ or $\mathrm{Me}$<smiles></smiles>

\section{Scheme 76}

Reaction of the pyrazoles 202 with carbon disulfide yielded the 2-mercapto-1-(5 pyrazolyl)benzimidazoles 205. When compounds 205 were treated with 1,2-dibromoethane in the presence of 18-crown-6, the pyrazolo[3,2- $d][1,3,5]$ thiadiazepino[3,2-a] benzimidazoles 206 were obtained (Scheme 77). ${ }^{110}$

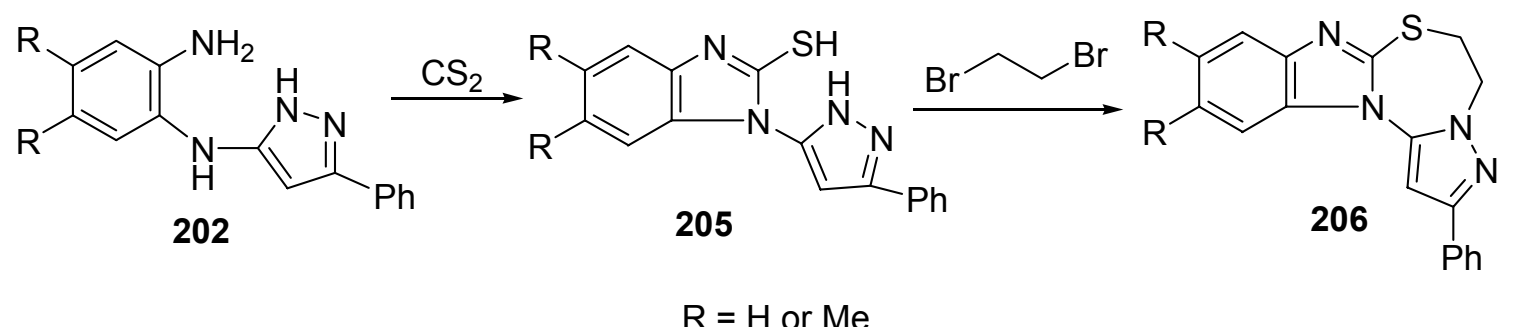

\section{Scheme 77}

Synthesis of the tetracyclic 1,3,5-triazino[1,2-a]benzimidazolium derivatives 210 starting from the methylbenzhydrylamine (MBHA) resin-bound benzimidazoles 207 was reported. Thus, 
treatment of $\mathbf{2 0 7}$ with triphenylphosphine at room temperature to give the iminophosphorane intermediates 208 which upon heating with halogenoalkyl isocyanates followed by resincleavage using anhydrous $\mathrm{HF}$ and anisole at $0{ }^{\circ} \mathrm{C}$ gave 210 as outlined in Scheme $78 .{ }^{111}$

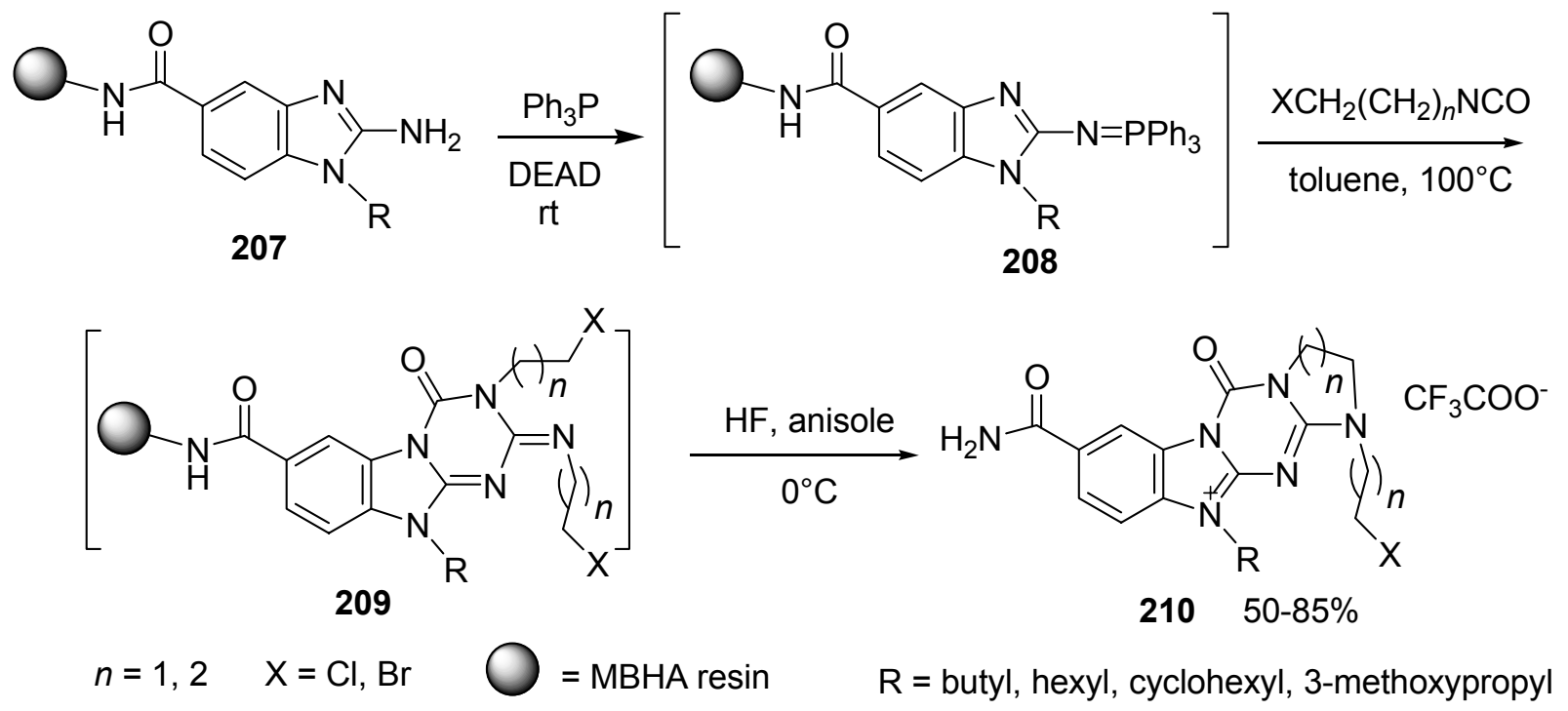

Scheme 78

\subsection{With six heteroatoms}

2.5.1. Benzimidazo[1,2-c]pyridazino[4,3-e]-1,2,3-triazines. Diazotization of 6-aminobenzimidazolylpyridazine 188 using sodium nitrite in acetic acid at $0-20{ }^{\circ} \mathrm{C}$ for $12 \mathrm{~h}$ followed by subsequent heating of the intermediate diazonium salt 211 yielded the benzimidazo[1,2c]pyridazino[4,3-e]-1,2,3-triazine 212 in 68\% yield (Scheme 79). ${ }^{112}$<smiles>Cc1nn([Al])c(N)c(-c2nc3ccccc3[nH]2)c1=O</smiles>

188

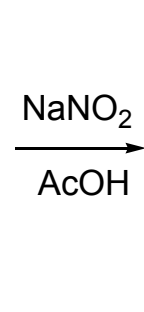

$\underset{\mathrm{AcOH}}{\stackrel{\mathrm{NNO}_{2}}{\longrightarrow}}$<smiles></smiles>

211<smiles>CCn1nc(C)c(=O)c2c1nnn1c3ccccc3nc21</smiles>

212

$$
\mathrm{Ar}=4-\mathrm{MeC}_{6} \mathrm{H}_{4}
$$

\section{Scheme 79}

2.5.2. Triazolo-triazino-benzimidazoles. Treatment of 2-chloro-1-cyanomethylbenzimidazole 213 with hydrazine in boiling methanol gave 3-hydrazino-1,2,4-triazino[4,3-a]benzimidazole 214. Reaction of $\mathbf{2 1 4}$ with carboxylic acids gave the triazolotriazinobenzimidazoles 215 in 70- 
$75 \%$ yield (Scheme 80$).{ }^{113}$<smiles>N#CCn1c(Cl)nc2ccccc21</smiles>

213

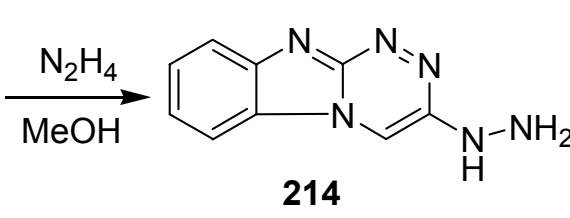

214<smiles>[R]C1=NNC2=Cn3c(nc4ccccc43)NN21</smiles>

$\mathrm{R}=\mathrm{H}, \mathrm{Me}, \mathrm{Ph}$

\section{Scheme 80}

Triazinone derivative 216 was converted into its thio-analogue 217 using phosphorus pentasulphide which was subsequently $S$-methylated then hydrazinated followed by cyclization via its reflux with formic acid to form 4-methyl-1,2,4-triazolo[4',3':4,5][1,2,4]triazino[2,3a]benzimidazole 218 (Scheme 81). ${ }^{114,115}$

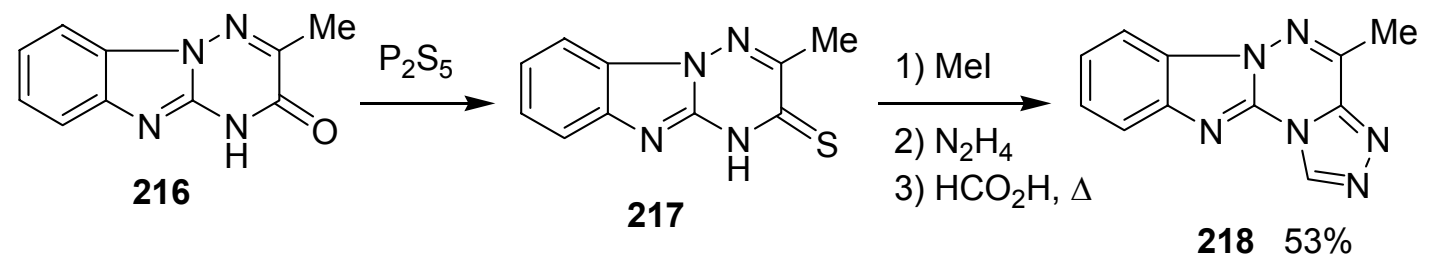

\section{Scheme 81}

2.5.3. Pyridazino[6,5-a]-1,2,4-triazino[2,3-a]benzimidazoles. Heating the ketone derivative 219 with arylhydrazines produced the arylhydrazones 220 which upon boiling in $\mathrm{POCl}_{3}$ underwent cyclization into the pyridazino[6,5-e]-1,2,4-triazino[2,3-a]benzimidazoles 221 (Scheme 82). ${ }^{116}$

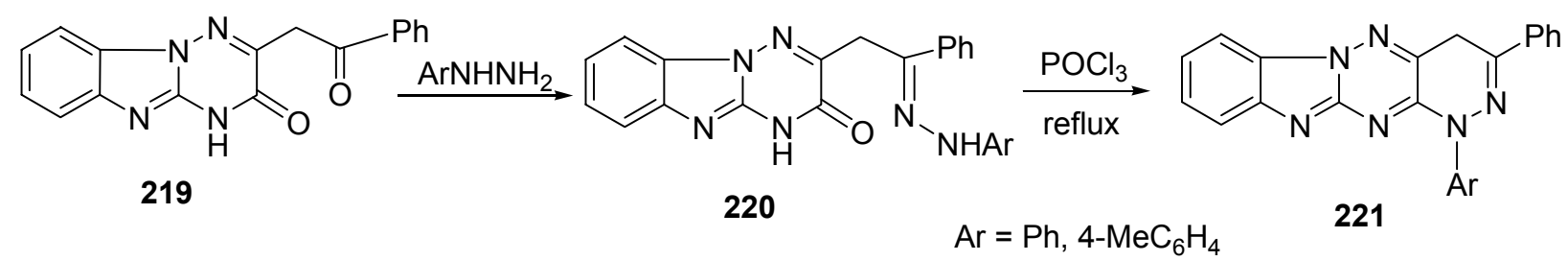

\section{Scheme 82}




\section{Pentacyclic fused benzimidazoles}

\subsection{With two heteroatoms}

Reaction of 2-benzimidazoleacetonitrile $\mathbf{4 2}$ with 2-dimethylaminomethylene-1,3-indandione 222 and with 2-dimethylaminomethylene-3-(phenylhydrazono)-indan-1-one $\mathbf{2 2 3}$ yielded the pentacyclic indeno-pyrido-benzimidazoles 224 and 225, respectively (Scheme 83). ${ }^{117}$<smiles>CN/C=C1/C(=O)c2ccccc2/C1=N/Nc1ccccc1C=C1C(=O)c2ccccc2C1=O</smiles>

\section{Scheme 83}

The preparation of 5-methyl-5,6-dihydrobenzimidazo[2,1-a]benzo[f]isoquinolines $\mathbf{2 2 9}$ is achieved conveniently in three steps as shown in Scheme 84. Thus, heating of 1-bromo-2naphthoic acid 226 with $o$-phenylenediamines 1 in polyphosphoric acid (PPA) gave 2-(1-bromo2-naphthyl)-1 $H$-benzimidazoles 227 which underwent $N$-allylation with sodium hydride and 3bromoprop-1-ene in THF to give 1-allyl-2-(1-bromo-2-naphthyl)benzimidazoles 228 in 68-88\% yield. $\mathrm{Bu}_{3} \mathrm{SnH}$ mediated cyclization of $\mathbf{2 2 8}$ in refluxing toluene afforded compounds 229 (Scheme 84). ${ }^{118}$<smiles>[R16]CCn1c(-c2ccc3ccccc3c2Br)nc2c([R])ccc([R])c21</smiles>

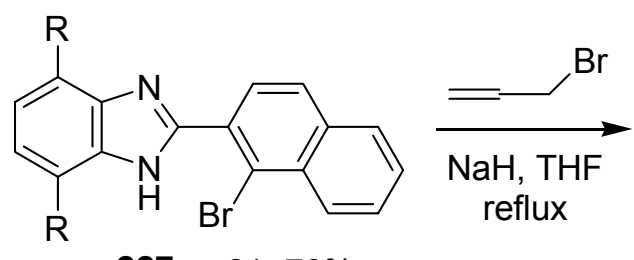

$22761 \sim 76 \%$<smiles>[R]c1ccc([R])c2c1nc1n2CC([Y6])c2c-1ccc1ccccc21</smiles>

$\mathrm{R}=\mathrm{H}, \mathrm{OMe}$

\section{Scheme 84}


(5,6-Dihydrobenzimidazo[1,2-b]benzo[f]isoquinolin-7-yl)-acetonitriles 235 were synthesized by the ring transformation of 4-(piperidin-1-yl)-2-oxo-5,6-dihydro- $2 H$-benzo[ $h]$ chromene-3carbonitriles 230 with 2-benzimidazoleacetonitrile 42 in the presence of powdered $\mathrm{KOH}$ in DMF. In this reaction, the carbanion formed in situ attacks at C-10b with ring opening and loss of carbon dioxide to give $\mathbf{2 3 2}$ followed by ring closure involving the ring nitrogen of benzimidazole and C-4 of the chromene ring to yield 235 in good yields via loss of piperidine as depicted in Scheme 85. ${ }^{119}$

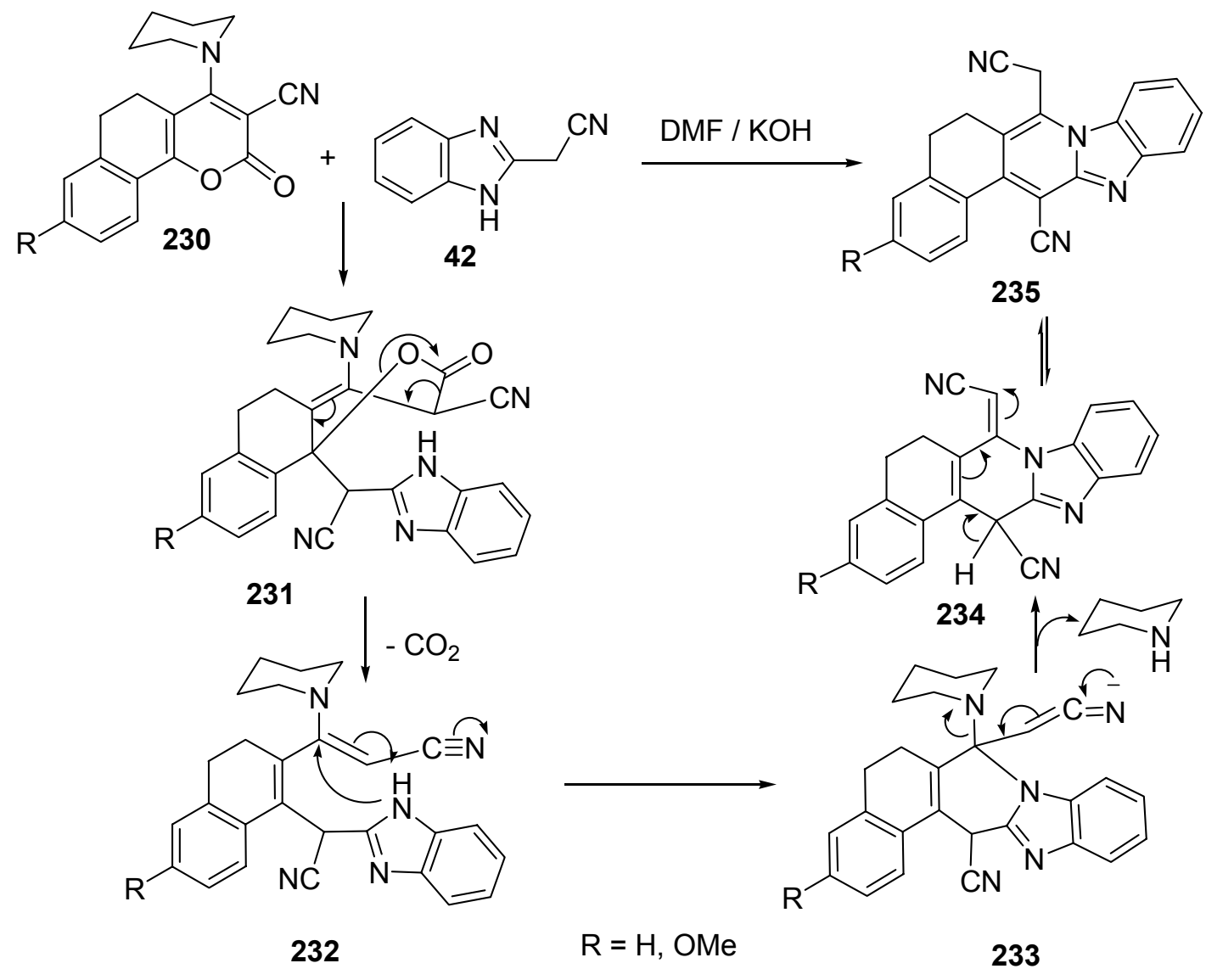

\section{Scheme 85}

Treatment of 1,8-naphthoic anhydride derivative 236 with $o$-phenylenediamine 1 in glacial acetic acid gave the pentacyclic fused system; $7 H$-benzimidazo[2,1-a]benzo[d,e]isoquinolin-7ones 237 (Scheme 86). ${ }^{120}$ 


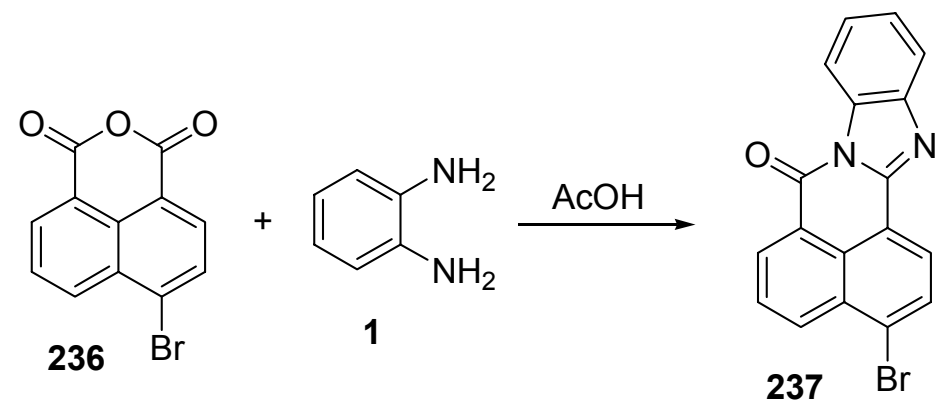

\section{Scheme 86}

\subsection{With three heteroatoms}

3.2.1. Thieno[2,3-b]pyrido[1,2-a]benzimidazoles. Heating benzimidazolyl-benzothiophene derivative 238 in di(p-bromophenyl)ether at reflux produced the benzothieno[2,3- $b]$ pyrido[1,2a]benzimidazole derivative 239 (Scheme 87). ${ }^{121}$<smiles>Cn1c(C(C#N)C(=O)c2sc3ccccc3c2Cl)nc2ccccc21</smiles>

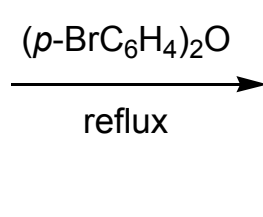<smiles>Cn1c2ccccc2n2c3c(sc4ccccc43)c(=O)c(C#N)c12</smiles>

\section{Scheme 87}

3.2.2. Indolo $[2,3-b]$ pyrido $[1,2-a]$ benzimidazoles. Heating a mixture of ethyl benzimidazole-2acetate $\mathbf{2 4 0}$ with the malonate esters $\mathbf{2 4 1}$ gave ethyl 3-hydroxy-1-oxo-pyrido[1,2a]benzimidazole-4-carboxylates 242. Heating the latter compounds 242 with $\mathrm{POCl}_{3}$ gave the corresponding 1,3-dichloro derivatives 243. Compound $243\left(\mathrm{R}=\mathrm{H}, \mathrm{R}^{1}=\mathrm{Ph}\right)$ was quantitatively converted into the 1-azido-3-chloropyrido[1,2-a]benzimidazole derivative 244 when treated with sodium azide in DMF. Refluxing the azido derivative $\mathbf{2 4 4}$ in bromobenzene gave the indolo[2,3b]pyrido[1,2-a]benzimidazole derivative 245 (Scheme 88). ${ }^{122}$ 
<smiles>[R]c1cc2nc(CCOC(=O)OCC)[nH]c2cc1[R]</smiles>

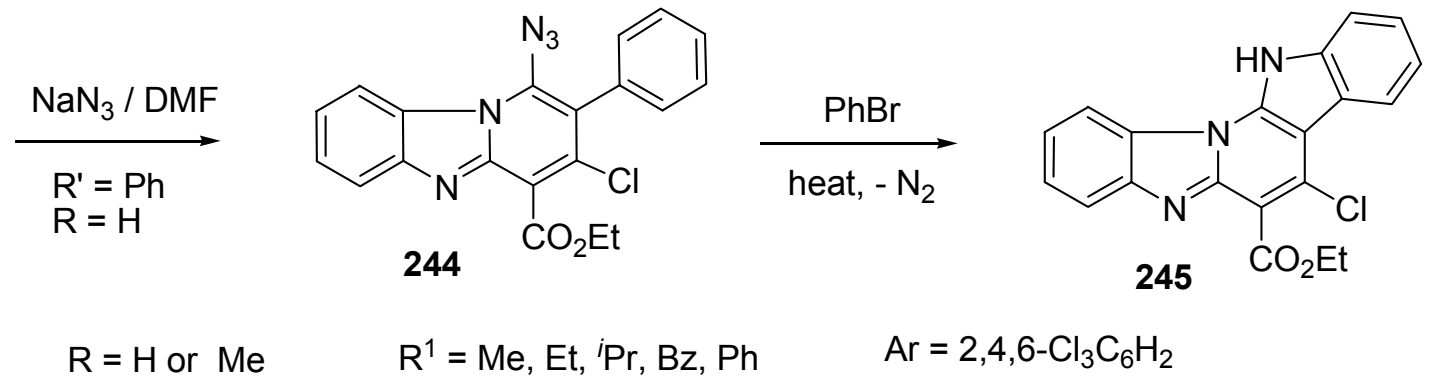

\section{Scheme 88}

3.2.3. Benzimidazo-pyrido-isoquinolines. 3-Chloroisoquinoline-4-carboxaldehydes 246 were condensed with 2-benzimidazoleacetonitrile $\mathbf{4 2}$ in DMF to give the benzimidazo-pyridoisoquinolines 247 (Scheme 89). ${ }^{123}$

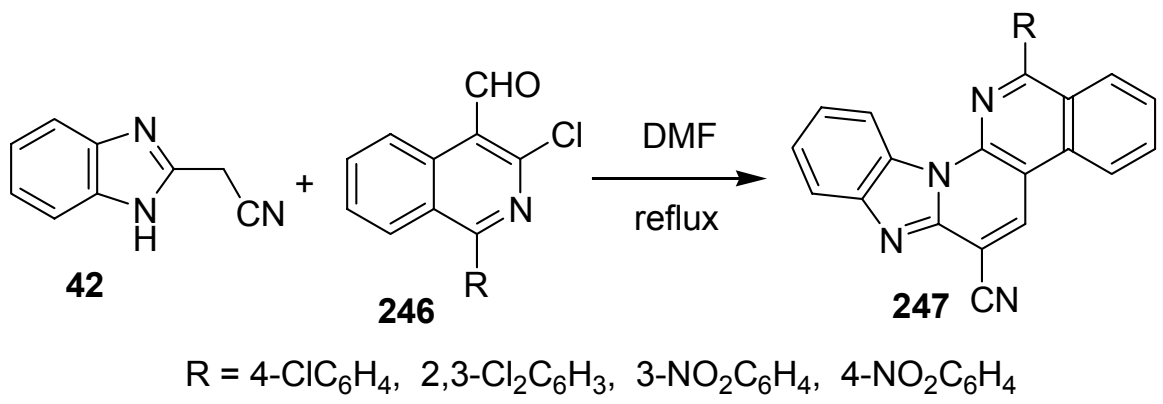

\section{Scheme 89}

3.2.4. Indeno $[1,2: 4,5]$ pyrimido $[1,2-a]$ benzimidazoles. Reaction of 2-arylideneindandiones 248 with 2-aminobenzimidazole 134 in refluxing ethanol yielded indeno[1,2:4,5]pyrimido[1,2a]benzimidazole-13-ones 249 in high yields (Scheme 90). ${ }^{124,125}$ 


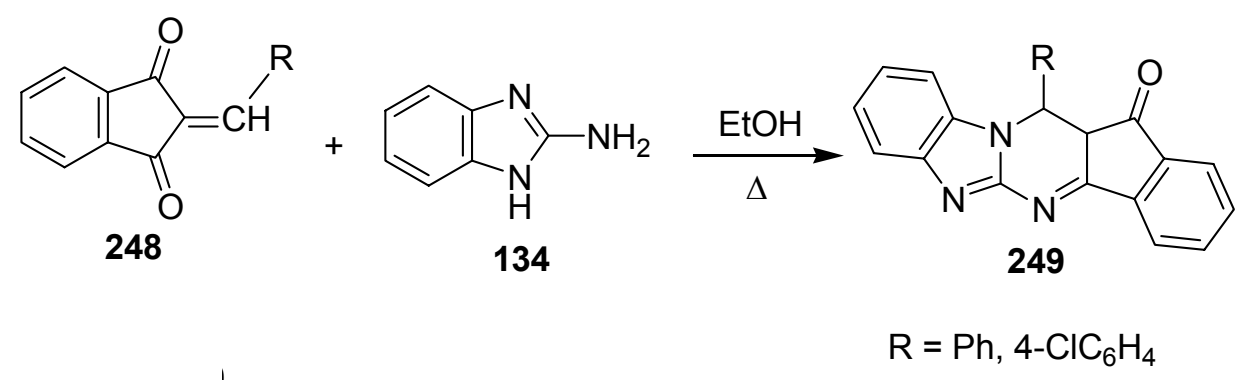

\section{Scheme 90}

\subsection{With four heteroatoms}

2-Amino-3-(benzimidazol-2-yl)thiochroman-4-one 251 was prepared by cyclocondensation of methyl thiosalicylate 250 with 2-benzimidazoleacetonitrile 42. Acylation of $\mathbf{2 5 1}$ with acid chlorides gave the benzimidazobenzothiopyranopyrimidines $\mathbf{2 5 2}$ (Scheme 91). ${ }^{106,126}$

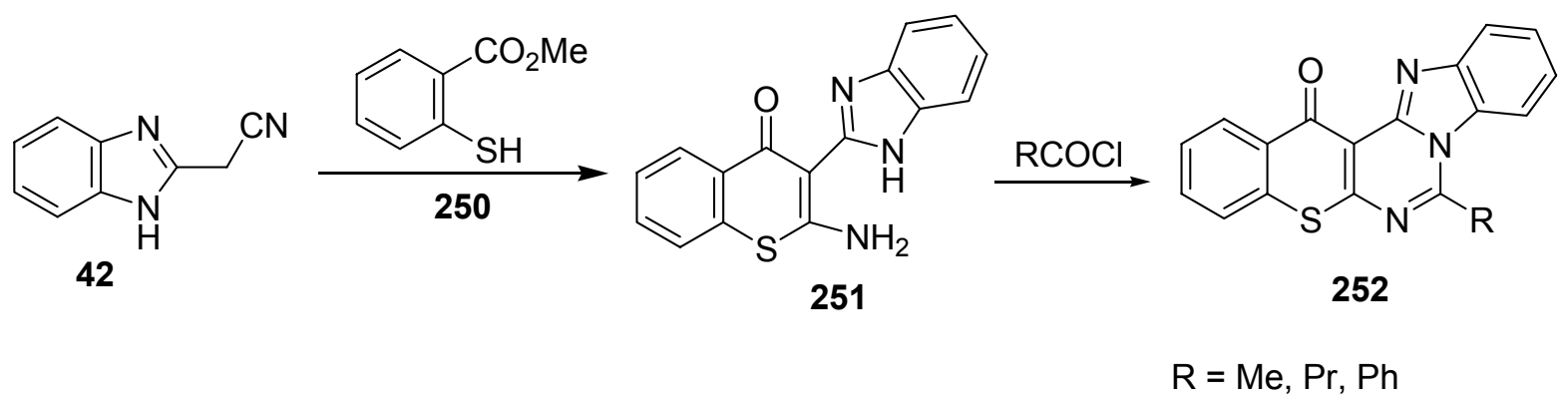

\section{Scheme 91}

Treatment of 2,3,5-trimethyl-1,4-benzoquinone 254 with 2-benzimidazoleacetonitrile $\mathbf{4 2}$ gave 2-amino-3-(2-benzimidazolyl)benzofuran 257 via the intermediates 255 and 256. Treatment of compound $\mathbf{2 5 7}$ with acid anhydrides or acid chlorides afforded the benzofuropyrimido-benzimidazoles 258 (Scheme 92). ${ }^{127}$ 


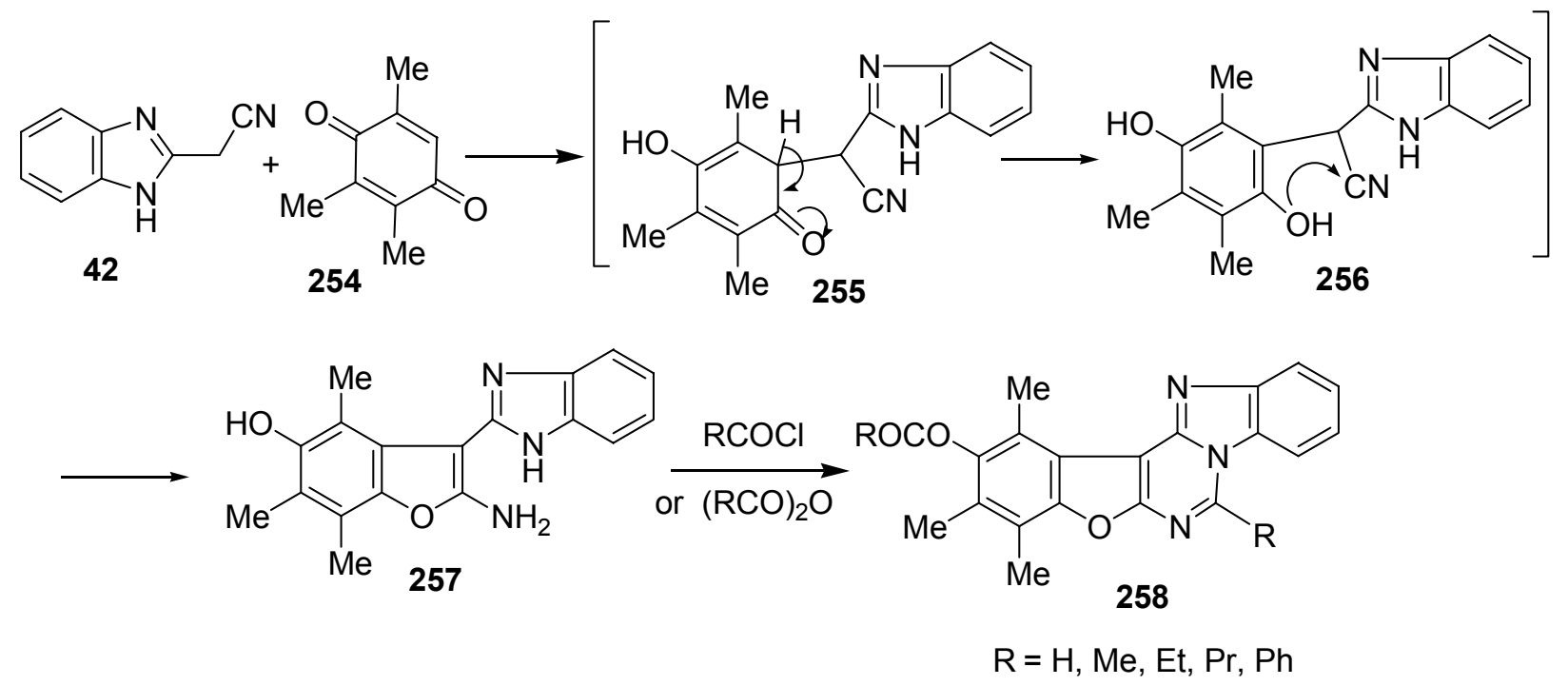

\section{Scheme 92}

4-Chloro-3-nitrocoumarin 259 underwent cyclization when treated with 2mercaptobenzimidazole 90 to give the coumarino-thiazolo-benzimidazole $\mathbf{2 6 0}$ (Scheme 93). ${ }^{124}$<smiles>O=c1oc2ccccc2c([N+](=O)[O-])c1Cl</smiles>

\section{Scheme 93}

Treatment of 1,5-dibromo-2,4-dinitrobenzene with pyrrolidine afforded 261, which was converted to $\mathbf{2 6 2}$ by reduction followed by acylation. Heating of 262 with formic acid at $70{ }^{\circ} \mathrm{C}$ in the presence of $\mathrm{H}_{2} \mathrm{O}_{2}$ underwent cyclization into $3 \mathrm{H}, 7 \mathrm{H}-1,2,8,9$-tetrahydropyrrolo[1,2-a]pyrrolo[1 $\left.{ }^{\prime}, 2^{`}: 1,2\right]$ imidazo[4,5-f] benzimidazole 263 in low yield (Scheme 94). ${ }^{128-130}$

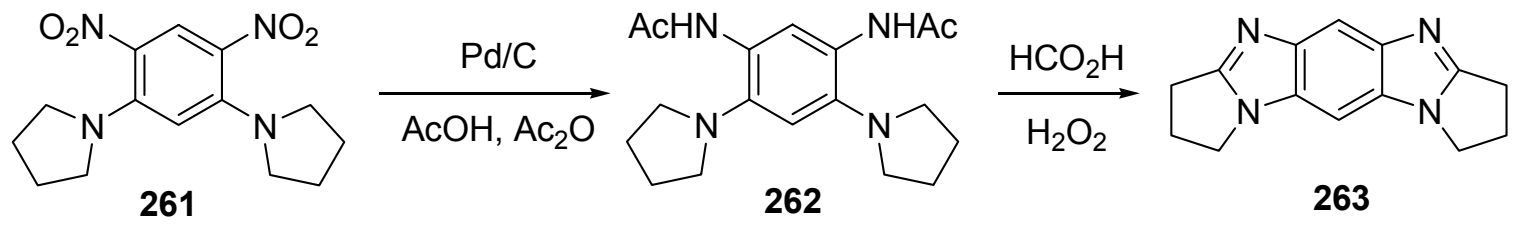

\section{Scheme 94}


Photochemical irradition of 4,6-dichloro-1,3-(N,N'-di(2-pyridyl)benzenediamine 264 in $80 \%$ aq. $t$-butanol gave the linear fused-pentacyclic system 265 in 47\% yield (Scheme 95). ${ }^{131,132}$

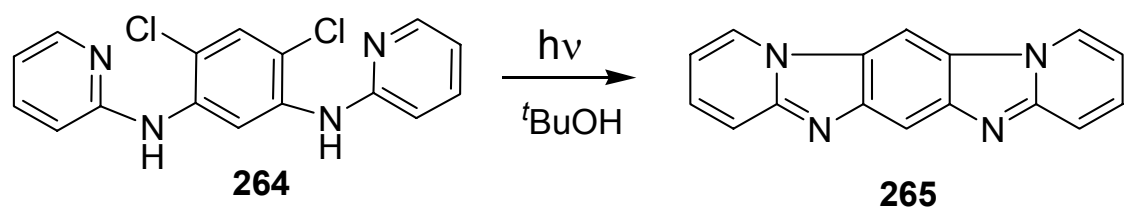

\section{Scheme 95}

Coupling of 2-dimethylaminomethylene-1-benzosuberone 266 with 2-aminobenzimidazole diazonium salt $\mathbf{2 6 7}$ gave 9,10-dihydro-8H-benzo[6',7']cyclohepta[1',2'-e]benzimidazo[2,1-c] $[1,2,4]$ triazine $\mathbf{2 7 0}$. The formation of the $\mathbf{2 7 0}$ is assumed to proceed via Japp-Klingemann-type cleavage of dimethylaminomethylene moiety from the intermediate $\mathbf{2 6 8}$ then loss of water from 269 (Scheme 96). ${ }^{133}$<smiles>C/C=C\C=C1/CCCc2ccccc2C1=O</smiles>

266<smiles>CC(=O)O[Na]</smiles>
267<smiles>CN=CC1(N=Nc2nc3ccccc3[nH]2)CCCc2ccccc2C1=O</smiles>

268

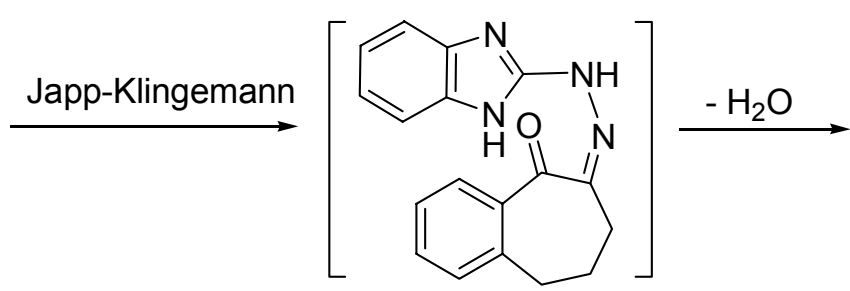

269<smiles>c1ccc2c(c1)CCCc1nnc3nc4ccccc4n3c1-2</smiles>

$27090 \%$

\section{Scheme 96}

Reaction of 2-hydrazinobenzimidazole 271 with tetracyanoethylene (TCNE) 272 gave the 1,2,4-triazepino[1,2-a]benzimidazole derivs 273 that react with dicyanomethyleneindane-1,3dione $\mathbf{2 7 4}$ to form the indeno-1,2,4-triazepino[1,2-a] benzimidazole derivative $\mathbf{2 7 5}$ in $83 \%$ yield (Scheme 97). ${ }^{134}$ 
<smiles>NN=c1[nH]c2ccccc2[nH]1</smiles>

271<smiles>CCCC(C)C(C#N)=C(C#N)C#N</smiles>

DMF<smiles>N#CC1=C(N)N=NC2=C(C#N)N1c1ccccc1N2</smiles>

273

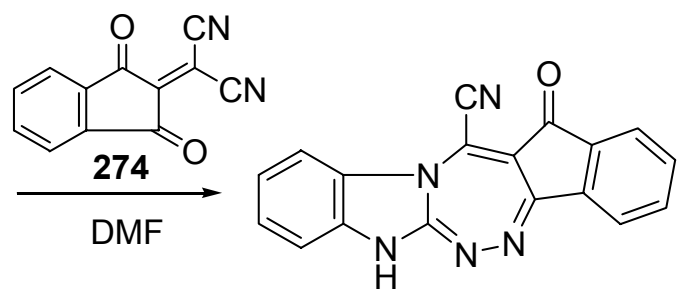

$27583 \%$

\section{Scheme 97}

\subsection{With five heteroatoms}

Treatment of the enaminone 276 with 2-aminobenzimidazole 134 in refluxing ethanol in the presence of piperidine resulted in the formation of pyrido[2", 3":2',3']-7Hthiopyrano[4',5':4,5]pyrimido[1,2-a] benzimidazole 278 via the initial attack of the endocyclic$\mathrm{NH}$ of $\mathbf{1 3 4}$ to the exocyclic enamine moiety of $\mathbf{2 7 6}$ followed by the loss of dimethylamine and water molecules from the intermediate 277 (Scheme 98). ${ }^{135}$

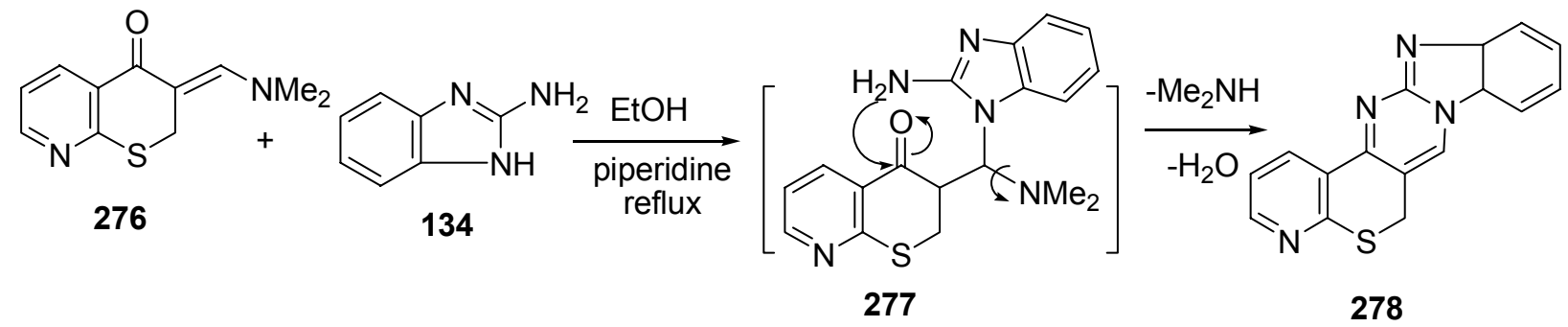

\section{Scheme 98}

Heating 2-amino-3-(2-benzimidazolyl)-1,8-naphthyridine 279 with aromatic aldehydes in acetic acid at reflux gave 6,7-dihydro-7-arylbenzimidazo[1',2':1,6]pyrimido[4,5b][1,8]naphthyridines $\mathbf{2 8 0}$ which upon oxidation with $\mathrm{KMnO}_{4}$ in acetone afforded 7arylbenzimidazo[1',2':1,6]pyrimido[4,5-b][1,8]naphthyridines $\mathbf{2 8 1}$ (Scheme 99). ${ }^{136}$<smiles>Nc1nc2ncccc2cc1-c1nc2ccccc2[nH]1</smiles>

279

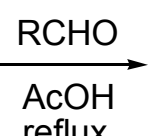
reflux<smiles>[R]C1Nc2nc3ncccc3cc2-c2nc3ccccc3n21</smiles>

280<smiles>[R]c1nc2nc3ncccc3cc2c2nc3ccccc3n12</smiles>

281

$$
\mathrm{R}=\mathrm{Ph}, 4-\mathrm{MeC}_{6} \mathrm{H}_{4} \text {, 2-thienyl }
$$

\section{Scheme 99}


Reaction of 2-chloromethylbenzimidazole $\mathbf{2 8 2}$ with 2-pyridinethione derivative $\mathbf{2 8 3}$ gave the theino[2,3-b]pyridine derivative 284. Reaction of $\mathbf{2 8 4}$ with triethyl orthoformate, acetic anhydride, 4-chlorobenzaldehyde and carbon disulfide led to the formation of pyrido[3",2":4',5']thieno[3',2':4,5]pyrimido[1,6-a]benzimidazole derivatives 285, 286, 287 and 288, respectively, in very high yields (Scheme 100). ${ }^{137}$<smiles>CCOC(=O)c1c(C)[nH]c(=S)c(C#N)c1[Al]Cl</smiles>

282<smiles>CCOCC(C)ON=O</smiles>

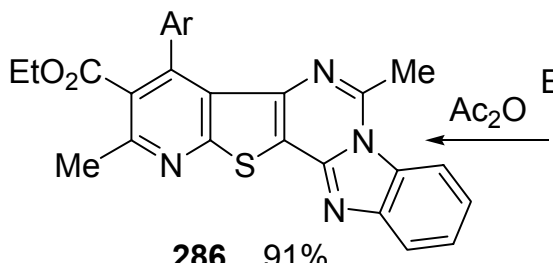
$28691 \%$<smiles>N[Al-2]</smiles><smiles>c1ccc2[nH]cnc2c1</smiles>

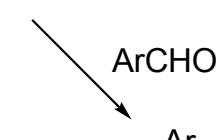<smiles>CCOCc1c(C)nc2sc3c(c2c1[Al])NC([Al])C([Al])N3C1=Nc2ccccc21</smiles>

$28782 \%$<smiles>CCOC(=O)c1c(C)nc2sc3c(nc(C)n4c5ccccc5nc34)c2c1Br</smiles><smiles>CCOC(=O)c1c(C)nc2sc3c([nH]c(=S)n4c5ccccc5nc34)c2c1Br</smiles>

$\mathrm{Ar}=4-\mathrm{ClC}_{6} \mathrm{H}_{4}$

\section{Scheme 100}

Synthesis of the pyrido[1',2':4,5]pyrazino[1,2-a]benzimidazole derivative 291 was reported from the reaction of lactam 290 with 2-fluoronitrobenzene 289 using $\mathrm{KOH}$ in dimethoxyethane (DME) in the presence of tetrabutylammonium fluoride, via elemination of HF followed by reduction of the nitro group then water elemination (Scheme 101). ${ }^{138}$

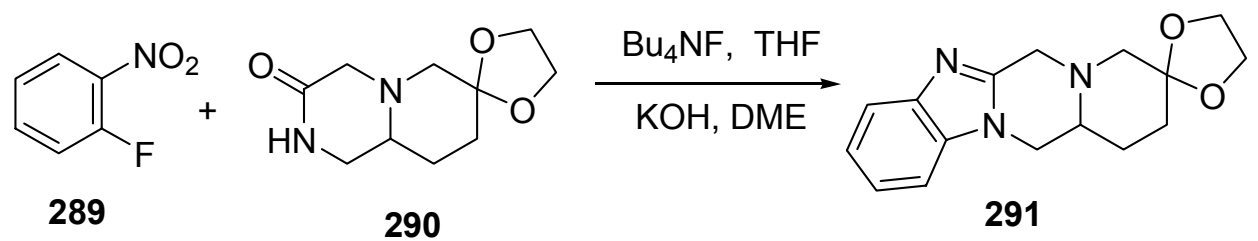

Scheme 101 


\subsection{With six heteroatoms}

Treatment of 3-methylthio-pyrimido[1,6-a]benzimidazole-4-carbonitrile 292 with hydrazine hydrate in refluxing ethanol gave the pyrazolo[ $\left[3^{\prime}, 4^{\prime}: 4,5\right]$ pyrimido[1,6- $\left.a\right]$ benzimidazole derivative 293. Reaction of $\mathbf{2 9 3}$ with the benzylidene derivatives $\mathbf{1 4 6}$ yielded pyrimido[2", $\left.1^{\prime \prime}: 5^{\prime}, 6^{\prime}\right]$ pyrazolo[3',4':4,5]pyrimido[1,6-a]benzimidazoles 294 (Scheme 102). ${ }^{139}$<smiles>CCOc1c(C#N)c2nc3ccccc3n2c(=O)n1C</smiles>
2920<smiles>Cn1c(=O)n2c3ccccc3nc2c2c(N)[nH]nc21</smiles>

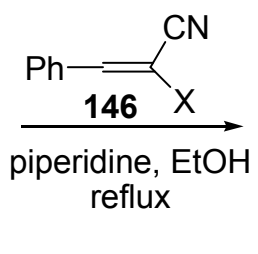

$\mathrm{X}=\mathrm{CN}, \mathrm{CO}_{2} \mathrm{Et}$<smiles>[X]c1c(-c2ccccc2)nc2c3c(nn2c1N)N(C)C(=O)N1C(N)C=CC=CC31</smiles>

294

\section{Scheme 102}

1,2,4-Triazolo-[2",3":6', 1']pyrimido[4',5':2,3]pyrido[1,2-a]benzimidazoles 295 and 296 were synthesized by refluxing 3-amino-4-imino-5-aryl-6-cyanopyrimido[5',4':5,6]-pyrido[1,2a] benzimidazole 149 with acetic anhydride and with ethyl chloroformate, respectively (Scheme 103). ${ }^{85}$

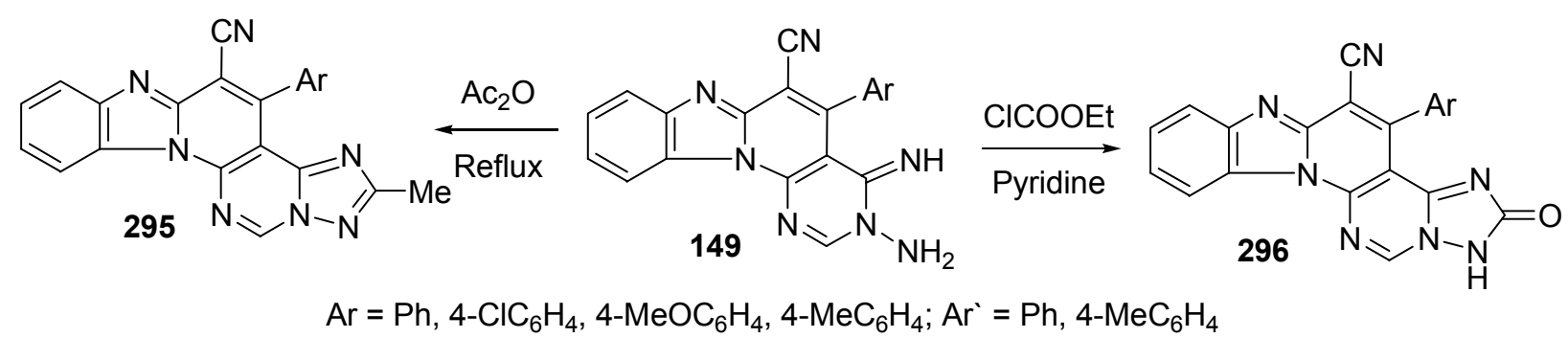

\section{Scheme 103}

\subsection{With seven heteroatoms}

Heating 2-methyl-3H-pyrimido[4',5':4,5]thiazolo[3,2-a]benzimidazol-4-one 176 in $\mathrm{POCl}_{3}$ followed by hydrazine hydrate gave 4-hydrazino-2-methylpyrimidino[4',5':4,5]thiazolo[3,2a] benzimidazole 297. Refluxing the latter 297 with triethylorthoformate afforded 5-methyl-1,2,4triazolo[4",3":3',4']pyrimidino[5',6':5,4]-thiazolo[3,2-a]benzimidazole 298 in $49 \%$ yield (Scheme 104). ${ }^{140}$ 
<smiles>Cc1nc2c(sc3nc4ccccc4n32)c(=O)[nH]1</smiles>

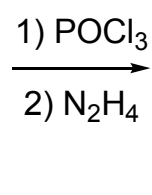<smiles>CCOC(C)C</smiles><smiles>Cc1nc2c(sc3nc4ccccc4n32)c2nncn12</smiles>

298

\section{Scheme 104}

Synthesis of azolo[5", $\left.1^{\prime \prime}: 3^{\prime}, 4^{\prime}\right][1,2,4]$ triazino[ $\left.5^{\prime}, 66^{\prime}: 4,5\right]$ pyrimido[1,6- $a$ benzimidazoles $\mathbf{3 0 2}$ is performed in one-step by the reaction of ethyl 2-cyanomethyl- $1 H$-benzimidazole-1-carboxylate 162 with the heterocyclic diazonium salts 299 via loss of ethanol from the intermediate 301 (Scheme 105). ${ }^{141}$

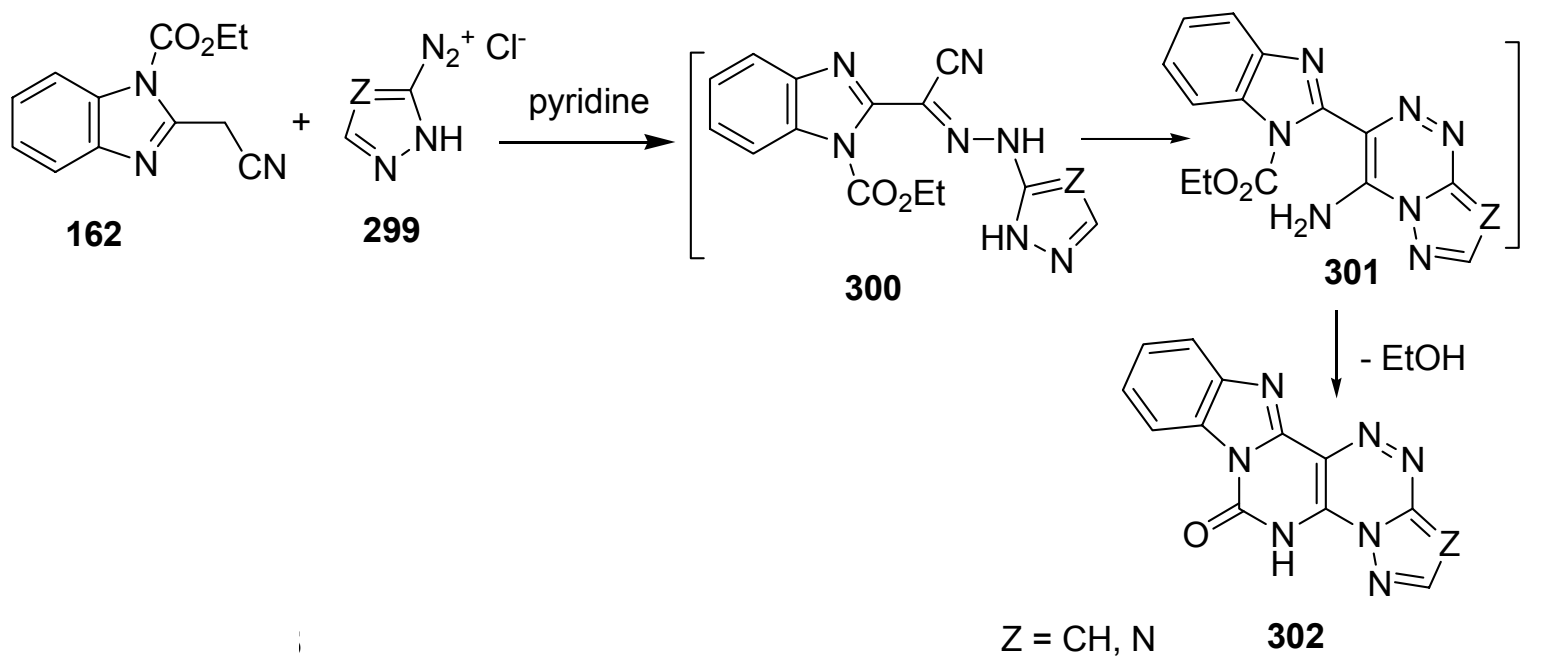

\section{Scheme 105}

Copper catalyzed cyclocondensation of 2-bromobenzoic acid $\mathbf{3 0 3}$ and 2-aminobenzimidazole 134 in $\mathrm{K}_{2} \mathrm{CO}_{3}$ and DMF at reflux afforded pyrido[3',2':5,6]pyrimido[1,2- $a$ ]benzimidazol-5(6H)one $304(\mathrm{X}=\mathrm{O})$ which up on treatment with phosphorus and sulfur in refluxing pyridine gave 5thione analogue $304(X=S)$. Treatment of $304(X=S)$ with hydrazine in refluxing ethanol followed by nitrosation gave the fused hexaazapentacyclic system $\mathbf{3 0 5}$ (Scheme 106). ${ }^{142}$

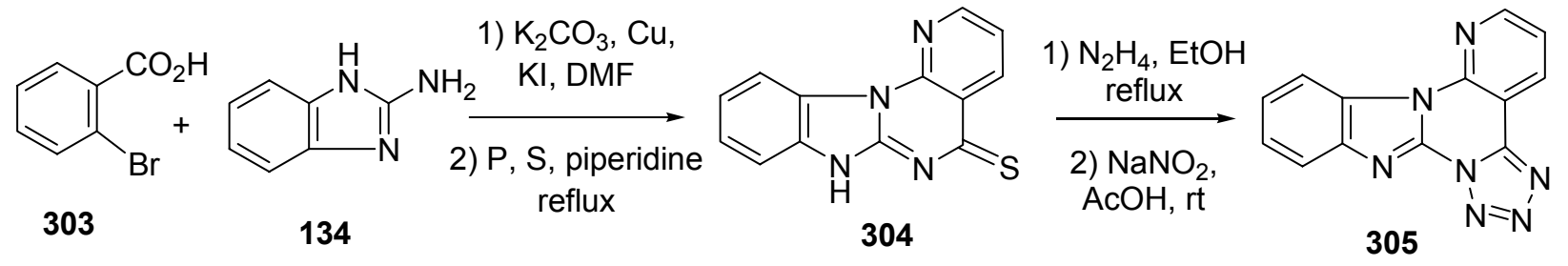

\section{Scheme 106}


Treatment of the pyrazolo[3',4':4,5]pyrimido[1,6- $a$ ] benzimidazole derivative 293 with active methylene derivatives in the presence of sodium nitrite and acetic acid yielded triazino[2", 1":5',6']pyrazolo[3',4':4,5]pyrimido[1,6-a]benzimidazoles 306 (Scheme 107) ${ }^{139}$<smiles>Cn1c(=O)n2c3ccccc3nc2c2c(N)[nH]nc21</smiles>

$\mathrm{X}=\mathrm{CN}, \mathrm{COMe} ; \mathrm{Y}=\mathrm{CN}, \mathrm{COMe}, \mathrm{CO}_{2} \mathrm{Et}$

1) $\mathrm{XCH}_{2} \mathrm{Y}$
2) $\mathrm{NaNO}_{2}, \mathrm{AcOH}$<smiles>[Y]c1nnc2c3c(nn2c1[R])N(C)C(=O)N1C3=NC2C=CC=CC21</smiles>

306

$$
\mathrm{R}=\mathrm{NH}_{2}, \mathrm{Me}
$$

\section{Scheme 107}

Heating benzimidazo[1,2-c]quinazoline-6(5H)-thiones $\mathbf{1 0 0}$ with hydrazine hydrate in ethanol followed by adding triethylorthoformate at reflux gave benzimidazo[1,2-c]-1,2,4-triazolo[4,3a]quinazoline 307 (Scheme 108). ${ }^{62,143}$

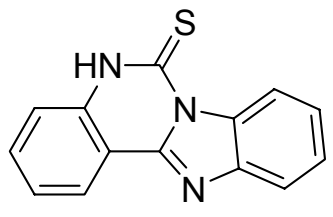

100

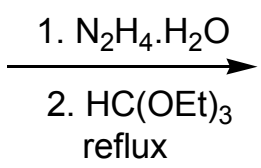

reflux<smiles></smiles>

307

\section{Scheme 108}

\section{Hexa- and heptacyclic fused benzimidazoles}

The pyrroloquinoline derivative $\mathbf{3 0 9}$ was prepared in good yield by treating 2benzimidazoleacetonitrile $\mathbf{4 2}$ with methyl tetrahydroquinoline-2-carboxylate $\mathbf{3 0 8}$ in refluxing pyridine containing sodium $t$-butoxide. Cyclization of $\mathbf{3 0 9}$ was performed in refluxing acetic anhydride to give the hexacyclic fused system $\mathbf{3 1 0}$ (Scheme 109). ${ }^{144}$ 


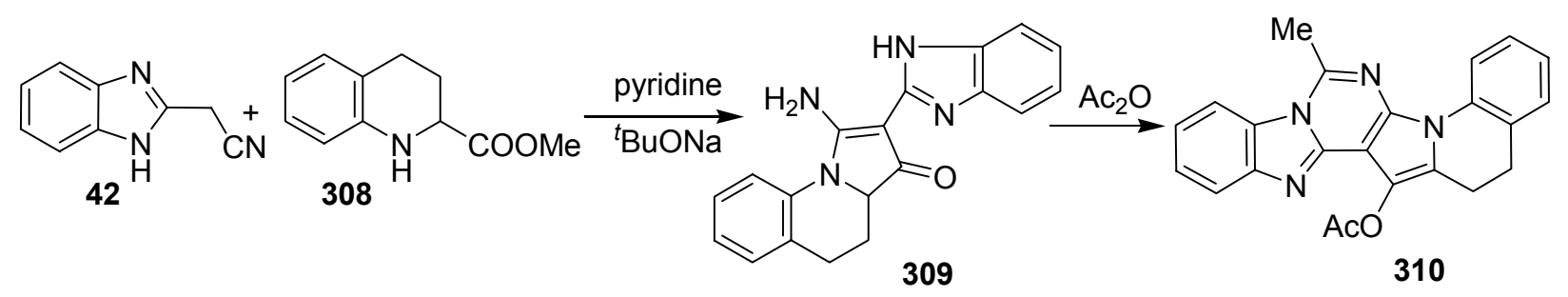

\section{Scheme 109}

Benzimidazole-2-diazonium salt $\mathbf{2 6 7}$ was coupled with 2-benzimidazoleacetonitrile 42 to yield the hydrazone 311 which was cyclized in refluxing pyridine to produce the 1,2,4triazino[4,3-a]benzimidazole 312. Heating the latter with ethyl chloroformate in refluxing pyridine produced the fused polyheterocycle 313 (Scheme 110). ${ }^{145}$<smiles>N#CCc1nc2ccccc2[nH]1</smiles>

42<smiles></smiles>

311
312

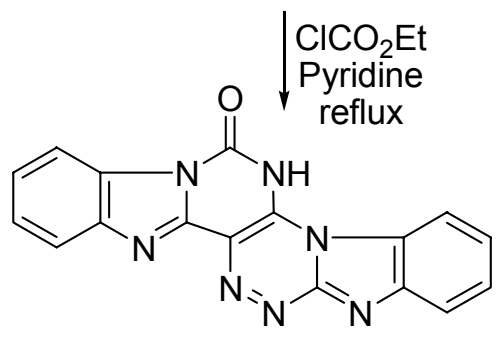

313

\section{Scheme 110}

Methylation of the mercaptobenzimidazo[1,2-c]quinazoline $\mathbf{1 0 0}$ with methyl iodide, in dimethylformamide, in the presence of sodium hydride gave the methylthio- derivative 314 in 95\% yield. Thermal heating of benzimidazoquinazoline 314 and anthranilic acids $\mathbf{3 1 5}$, neat at $120{ }^{\circ} \mathrm{C}$ or in butanol at reflux for $48 \mathrm{~h}$, cannot give more than $50 \%$ of the polyheterocyclic skeleton: $\quad 5 \mathrm{a}, 10,14 \mathrm{~b}, 15$-tetraaza-benzo[ $[a]$ indeno[1,2-c]anthracen-5-ones $316 . \quad$ However, microwave irradiation of $\mathbf{3 1 5}$ with $\mathbf{3 1 4}$ on carbon graphite as support led to the formation of compounds 316 in good yields and in shorter times than for the purely thermal procedures (Scheme 111). ${ }^{60}$ 


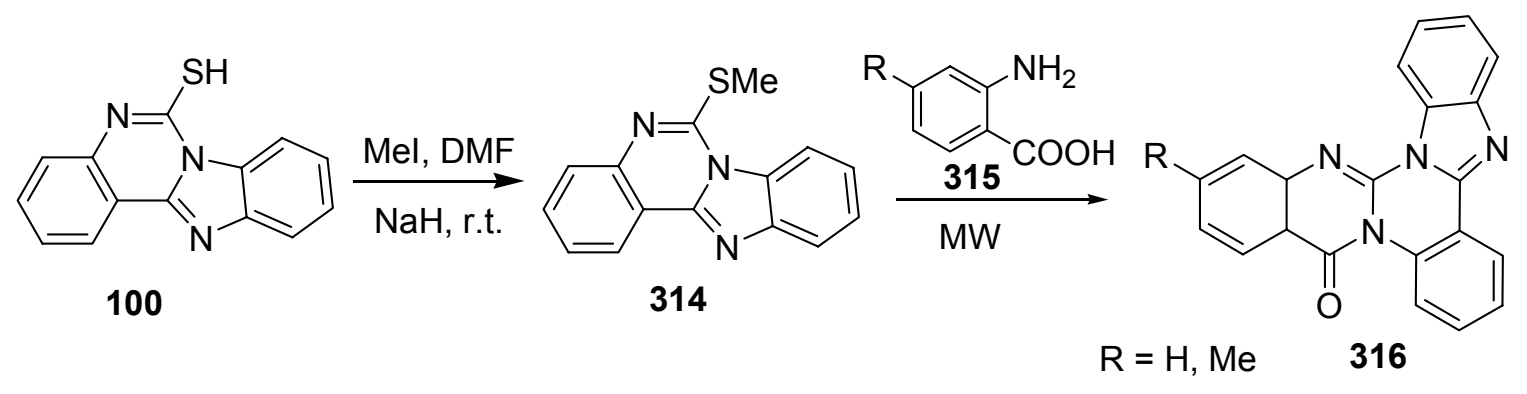

\section{Scheme 111}

Phenanthreno[9,10-e]-1,2,4-triazino[2,3-a]benzimidazole $\mathbf{3 1 8}$ was prepared by cyclocondensation of 1,2-diaminobenzimidazole $\mathbf{1 7 0}$ with phenanthrene-9,10-dione 317 in refluxing xylene (Scheme 112). ${ }^{146}$

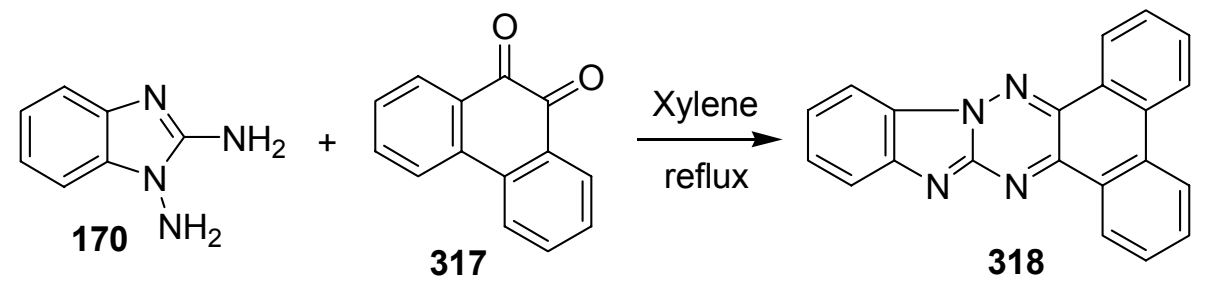

\section{Scheme 112}

Reaction of 2,5-bis(bromomethyl)benzene-1,4-dinitrile 319 with $o$-phenylenediamine 1 led to the formation of polycyclic skeleton 320 (Scheme 113). ${ }^{147}$<smiles>N#Cc1cc(CBr)c(CBr)cc1CBr</smiles>

\section{Scheme 113}

Diaminopyrrolobenzimidazole 321 underwent a condensation reaction with phenanthrene9,10-dione $\mathbf{3 1 7}$ in acetic acid at reflux to give the hepta-fused-heterocyclic system $\mathbf{3 2 2}$ (Scheme 114). ${ }^{148}$ 
<smiles>Nc1ccc2nc3n(c2c1N)CC[CH+]3</smiles>

322

\section{Scheme 114}

Reaction of 2-methylbenzimidazole 70 with 3-dicyanomethylidine-1-ethyl-2-oxoindoline 323, in ethyl acetate and $\mathrm{Et}_{3} \mathrm{~N}$, afforded 1-amino-2-cyano-3,4-dihydro-1'ethylspiro\{benzimidazo[1,2-a]pyridine-3,3'-indolin\}-2'-one 325. Reaction of 325 with $o$ phenylenediamine $\mathbf{1}$ in refluxing ethanol containing few drops of pyridine gave the benzimidazolyl spiropolyheterocycle $\mathbf{3 2 6}$ which reacts with triethylorthoformate to give the poly-fused heterocyclic system; 6,7-dihydro-1' -ethylspiro\{benzimidazo[1',2':1,6]pyrido[2,3$d$ ]benzimidazo[2",1"-f]pyrimidine-6,3'-indolin\}-2'-one 327 in 45\% yield (Scheme 115). ${ }^{149}$
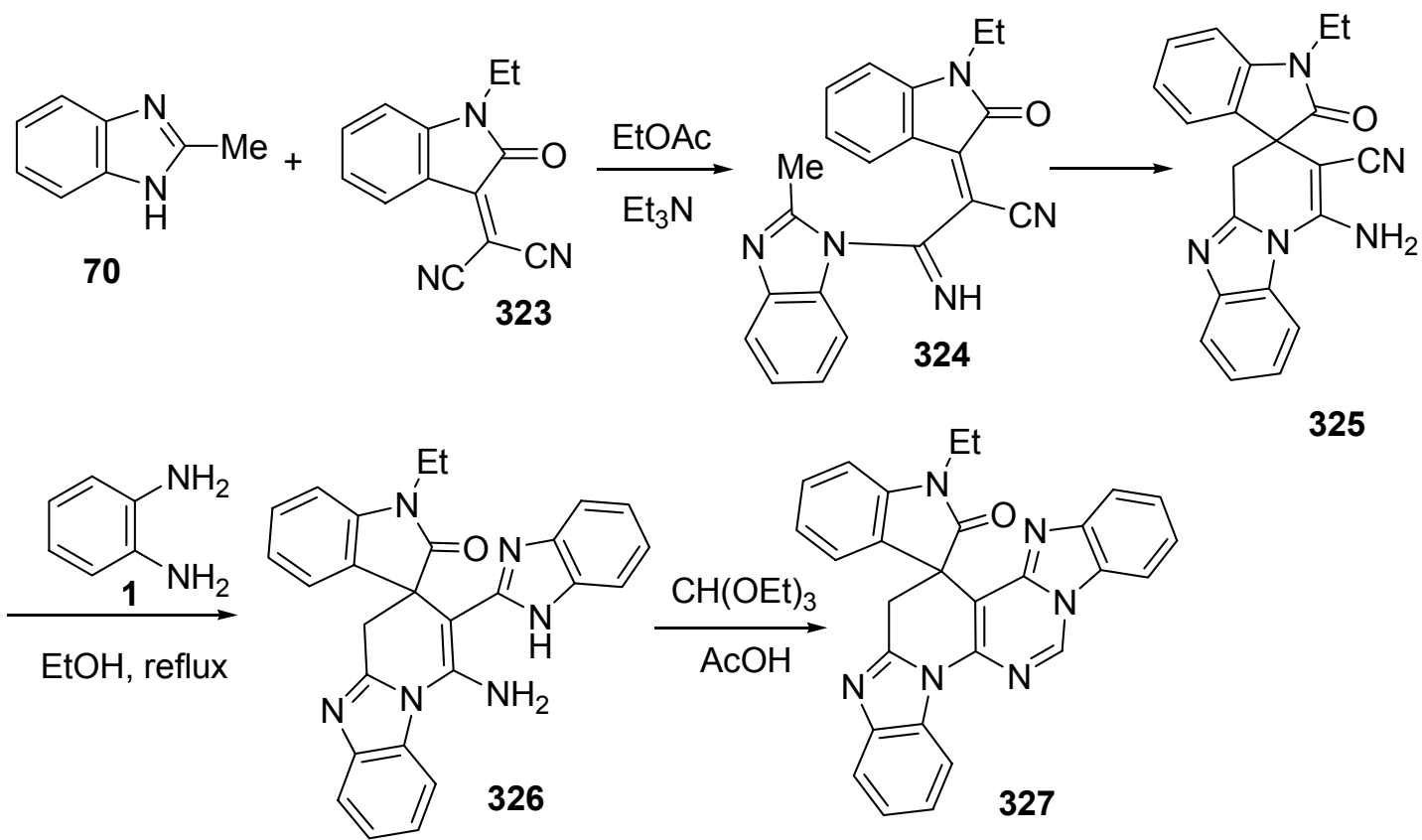

325

\section{Scheme 115}

Bis-hydrazonoyl chlorides 329 reacted with 2-methylthiobenzimidazole 328 in 1:2 molar ratio in refluxing ethanol in the presence of triethylamine and gave 1,1'-diaryl-3,3'-bi-1,2,4- 
triazolo[4,5-a] benzimidazoles $\mathbf{3 3 1}$ via loss of two molecules of MeSH from the intermediate $\mathbf{3 3 0}$ (Scheme 116). ${ }^{150}$<smiles>Cc1nc2ccccc2[nH]1</smiles>

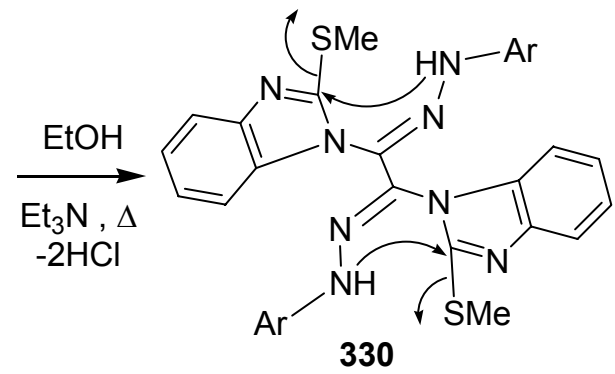<smiles>CCCCCn1nc(-c2nn(CCC)c3nc4ccccc4n23)n2c3ccccc3nc12</smiles>

$\mathrm{Ar}=\mathrm{Ph}, 4-\mathrm{ClC}_{6} \mathrm{H}_{4}$

\section{Scheme 116}

Condensation of 3,5-di-(tert-butyl)-1,2-benzoquinone 332 with 2-methylbenzimidazoles $\mathbf{7 0}$ proceeded under reflux in $o$-xylene to yield the benzimidazolylidene derivative 333. Reaction of the latter $\mathbf{3 3 3}$ with another molecule of 2-methylbenzimidazole $\mathbf{7 0}$ then rearranged to give the intermediate $\mathbf{3 3 4}$ which upon oxidation by an excessive amount of the $o$-quinone $\mathbf{3 3 2}$ gave rise to the polycyclic fused benzimidazoles 337 (Scheme 117). ${ }^{151}$<smiles></smiles>

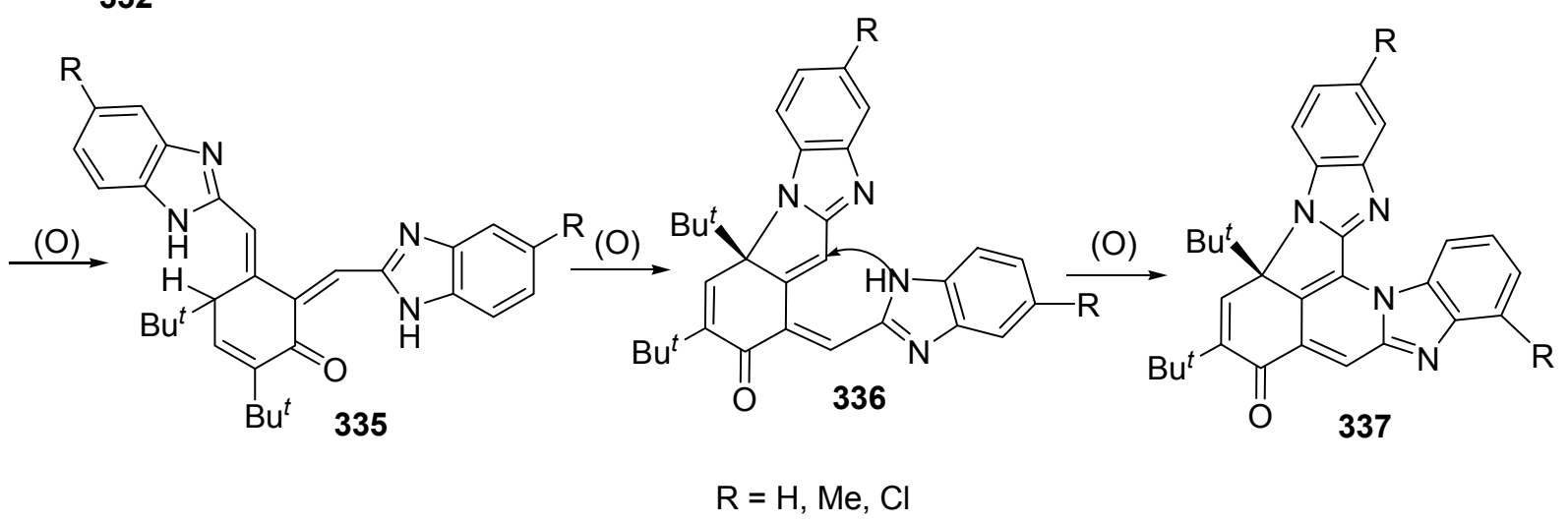

Scheme 117 
Reaction of 3- $\beta$-acetoxy-17-chloro-16-formyl-5 $\alpha$-androst-16-ene 338 with 2benzimidazoleacetonitrile $\mathbf{4 2}$ in refluxing ethanol in the presence of piperidine yielded the benzimidazopyridoandrostane derivative 339 in high yield (Scheme 118). ${ }^{152}$

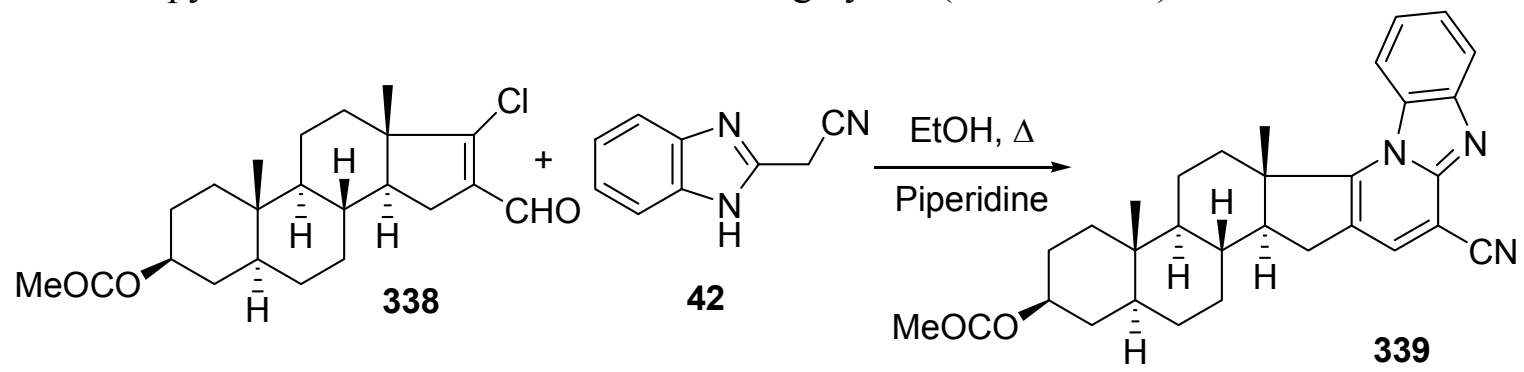

\section{Scheme 118}

Treatment of 2-hydroxymethylene-3-androstanone derivative $\mathbf{3 4 0}$ with 2aminobenzimidazole $\mathbf{1 3 4}$ in refluxing ethanol gave the androstano[3,2- $b]$ pyrimido[1,2a] benzimidazole derivatives 341 in excellent yields (Scheme 119). ${ }^{153,154}$

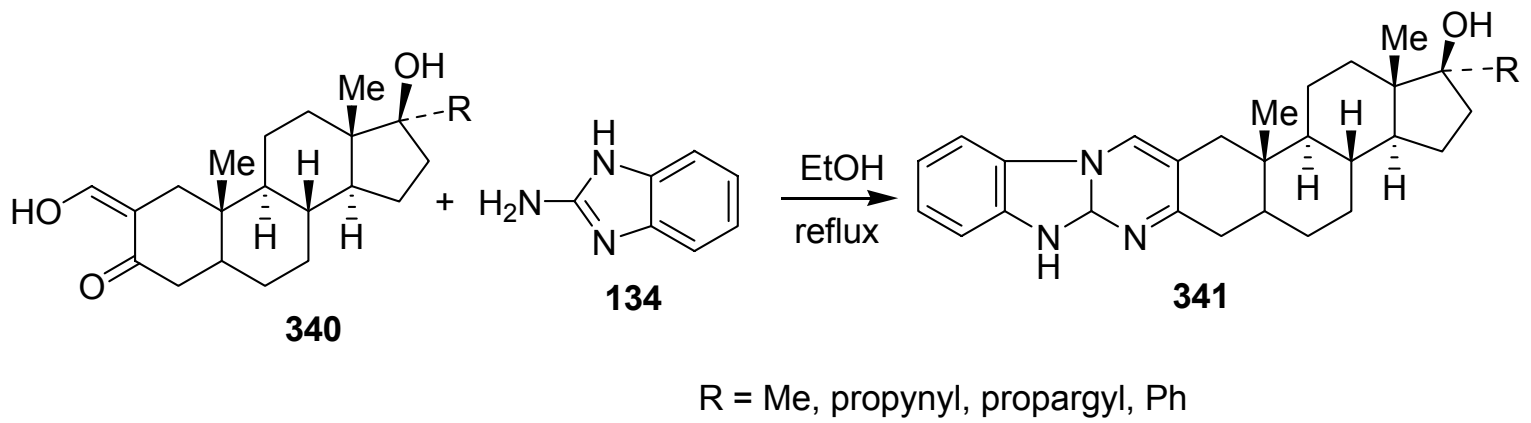

\section{Scheme 119}

Cyclocondensation reaction of 2-bromo-3-cholestanone 342 with 2-mercaptobenzimidazole 90 under refluxing ethanol gave the cholestano-thiazolo-benzimidazole derivatives 343 (Scheme 120). ${ }^{155}$

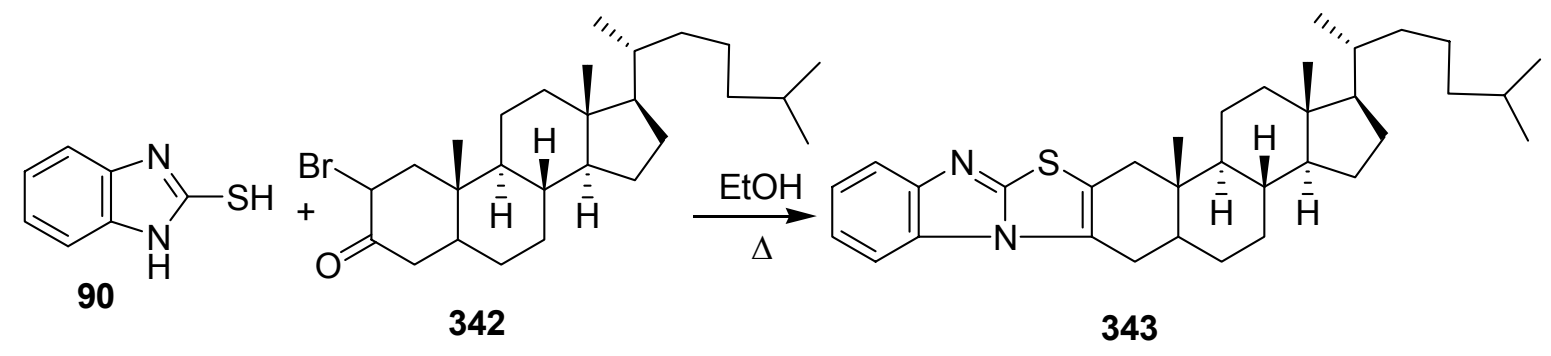

Scheme 120 


\section{References}

1. Lednicer, D. Strategies for Organic Drug Synthesis and Design, John Wiley \& Sons: New York, 1998.

2. Silverman, R. B. The Organic Chemistry of Drug Design and Drug Action, 2nd Edn. Elsevier Academic Press: Oxford, 2004.

3. Demeunynck, M.; Bailly, C.; Wilson, W. D.; D.N.A. and R.N.A. Binders, Wiley-VCH: Weinheim, 2002.

4. Helissey, P.; Cros, S.; Giorgi-Renault, S. Anti-Cancer Drug Des. 1994, 9, 51.

5. Brana, M. F.; Castellano, J. M.; Keilhauer, G.; Machuca, A.; Martin, Y.; Redondo, C.; Schlick, E.; Walker, N. Anti-Cancer Drug Des. 1994, 9, 527.

6. Riou, J. F.; Helissey, P.; Grondard, L.; Giorgi-Renault, S. Mol. Pharmacol. 1991, 40, 699.

7. Ibrahim, E.; Montgomerie, A. M.; Sneddon, A. H.; Proctor, G. R.; Green, B. Eur. J. Med. Chem. 1988, 23, 183.

8. Vivas-Mejía, P.; Cox, O.; Gonzalez, F. A. Mol. Cell. Biochem. 1998, 178, 203.

9. Deady, L. W.; Rodemann, T.; Finalay, G. J.; Baguley, B. C.; Denny, W. A. Anticancer Drug Des. 2001, 15, 339.

10. Wand, W. R.; Harrison, S. D.; Gilbert, K. S.; Laster, W. R.; Griswold, D. P. Cancer Chemother. Pharmacol. 1991, 27, 456

11. Carpenter, R. D.; Lam, K. S.; Kurth, M. J. J. Org. Chem. 2007, 72, 284.

12. Panda, K.; Suresh, J. R.; Illa, H.; Junjappa, H. J. Org. Chem. 2003, 68, 3498.

13. William, H. J. US Pat 3,329,684, 1967; Chem Abstr. 1967, 67, 108656.

14. Patel, K. M.; Patel, V. H.; Patel, M. P.; Patel, R. G. Dyes and Pigm. 2002, 55, 53.

15. Al-Khathlan, H.; Zimmer, H. J. Heterocycl. Chem. 1988, 25, 1047.

16. Meegalla, S. K.; Stevens, G. J.; McQueen, C. A.; Chen, A. Y.; Yu, C.; Liu, L. F.; Barrows, L. R.; LaVoie, E. J. J. Med. Chem. 1994, 37, 3434.

17. Mukherjee, A.; Akhar, M. S.; Sharma, V. L.; Seth, M.; Bhaduri, A. P.; Agnihotri, A.; Mehrota, P. K.; Kamboj, V. P. J. Med. Chem. 1989, 32, 2297.

18. Bedair, A. H.; Lamphon, R. Q.; Ghazal, S. A. J. Chem. Pak. 1988, 10, 404; Chem. Abstr. 1990, 112, 20869.

19. Tamborski, C.; Prabhu, U. D. G.; Eapen, K. C. J. Fluorine Chem. 1985, 28, 139.

20. Louvet, P.; Thomasson, F.; Cong, L. D. J. Heterocycl. Chem. 1994, 31, 39.

21. Cul, A.; Daich, A.; Decroix, B.; Sanz, G.; Hijfte, L. V. Tetrahedron 2004, 60, 11029.

22. Stajer, G.; Csende, F.; Bernath, G.; Sohar, P. Heterocycles, 1994, 37, 883.

23. Sillanpaeae, R.; Csende, F.; Stayer, G. Acta Crystallogr. 1995, C51, 2169.

24. Eguchi, S.; Matsushita, Y.; Takauchi, H. J. Org. Chem. 1992, 57, 6975.

25. Allin, S. M.; Bowman, W. R.; Karim, R.; Rahman, S. S. Tetrahedron 2006, 62, 4306.

26. Hubbard, J. W.; Piegols, A. M.; Söderberg, B. C. G. Tetrahedron 2007, 63, 7077.

27. Dyker, G.; Stirner, W.; Henkel, G. Eur. J. Org. Chem. 2000, 8, 1433. 
28. Okamoto, N.; Sakurai, K.; Ishikura, M.; Takeda, K.; Yanada, R. Tetrahedron Lett. 2009, 50, 4167.

29. Donaghy, M. J.; Stanforth, S. P. Tetrahedron 1999, 55, 1441.

30. Alajarin, M.; Vidal, A.; Tovar, F.; Conesa, C. Tetrahedron Lett. 1999, 40, 6127.

31. Alajarin, M.; Vidal, A.; Tovar, F. Tetrahedron Lett. 2000, 41, 7029.

32. Nemazanyi, A. G.; Volovenko, Y. M.; Silaeva, T. A.; Babichev, F. S. Dok. Akad. Nauk SSSR 1990, 310, 1135; Chem. Abstr. 1990, 113, 78221.

33. Volovenko, Y. M.; Nemazanyi, A. G.; Ryabokon, I. G.; Babichev, F. S. Ukr. Khim. Zh. 1988, 54, 295; Chem. Abstr. 1989, 110, 38921.

34. Volovenko, Y. M.; Nemazanyi, A. G.; Shevchenko, V. A.; Babichev, F. S. Geol. Khim. Biolog. Nauki 1983, 9, 27; Chem. Abstr. 1984, 100, 6393.

35. (a) Badawey, E. S. A. M.; Kappe, T. Eur. J. Med. Chem. 1999, 34, 663; (b) Badawey, E. S. A. M.; Rida, S. M.; Soliman, F. S. G.; Kappe, T. Monatsh. Chem. 1987, 120, 73.

36. Russell, R. K.; van Nievelt, C. E. R. W. J. Heterocycl. Chem. 1995, 32, 299.

37. Ling, K. Q.; Chen, X. Y.; Fun, H. K.; Hang, X. Y.; Xu, J. H. J. Chem. Soc. Perkin Trans. I, 1998, 24, 4147.

38. Weinkauf, R. L.; Chen, A. Y.; Yu, C.; Liu, L.; Barrows, L.; LaVoiel, E. J. Bioorg. Med. Chem. 1994, 2, 781.

39. Hranjec, M.; Karminski-Zamola, G. Molecules 2007, 12, 1817.

40. Shenoy, V. U.; Seshadri, S. Dyes and Pigm. 1989, 11, 137.

41. Tkach, I. I.; Lukyanets, E. A. Chem. Heterocycl. Compd. 1992, 8, 881.

42. Khilya, O. V.; Volovnenko, T. A.; Turov, A. V.; Volovenko, Y. M. Chem. Heterocycl. Compd. 2004, 40, 1063.

43. Khilya, O. V.; Volovenko, T. A.; Turov, A. V.; Volovenko, Y. M. Ukr. Khim. Zh. 2003, 69, 55; Chem. Abstr. 2003, 140, 217587.

44. Gorobets, N. Y.; Yousefi, B. H.; Belaj, F.; Kappe, C. O. Tetrahedron 2004, 60, 8633.

45. Nosova, E. V.; Lipunova, G. N.; Laeva, A. A.; Charushin, V. N. Russ. Chem Bull. 2005, $54,733$.

46. Abe, N.; Ishikawa, N.; Hayashi, T.; Miura, Y. Bull. Chem. Soc. Jpn. 1990, 63, 1617.

47. Prostakov, N. S.; Varlamov, A. V.; Shendrik, I. V.; Krapivko, A. P.; Golovtsov, N. I. Chem. Heterocycl. Compd. 1986, 2, 239.

48. Lee, H. S.; Kim, S. H.; Gowrisankar, S.; Kim, J. N. Tetrahedron 2008, 64, 7183.

49. Volovenko, Y. M.; Dubinina, G. G. Chem. Heterocycl. Compd. 2001, 37, 122.

50. Tereshchenko, A. D.; Tolmachev, A. A.; Tverdokhlebov, A. V. Synthesis 2004, 373.

51. Rajadhyaksha, D. D.; Rangnekar, D. W. Indian J. Chem. 1987, $26 B, 143$.

52. Nath, M.; Srivastava, P.; Goel, A.; Ram, V. J. Eur. J. Org. Chem. 1998, 10, 2083.

53. Badawey, E. S. A. M.; Kappe, T. Eur. J. Med. Chem. 1995, 30, 327.

54. Dolbier, W. R., Jr.; Burkholdoer, C.; Abboud, K. A.; Loehle, D. J. Org. Chem. 1994, 59, 7688.

55. Khajavi, M. S.; Rad-Moghadam, K.; Hazarkhani, H. Synth. Commun. 1999, 29, 2617. 
56. Shi, D.-Q.; Li, Z.-Y.; Dou, G.-L.; Shi, C.-L.; Wang, X.-S.; Ji, S.-J. Gaodeng Xuexiao Huaxue Xuebao 2007, 28, 1889; Chem. Abstr. 2007, 149, 355834.

57. Domany, G.; Gizur, T.; Gere, A.; Takacs-Novak, K.; Farsang, G.; Ferenczy, G. G.; Tarkanyi, G.; Demeter, M. Eur. J. Med. Chem. 1998, 33, 181.

58. Lamazzi, C.; Leonce, S.; Pfeiffer, V; Reanard, P.; Guillaument, G. ; Rees, C. W.; Besson, T. Bioorg. Med. Chem. Lett. 2000, 10, 2183.

59. Frère, S.; Thièry, V.; Bailly, C.; Besson, T. Tetrahedron 2003, 59, 773.

60. Soukri, M.; Guillaumnet, G.; Besson, T.; Aziane, D.; Aadil, M.; Essassi, E. M.; Akssirra, M. Tetrahedron Lett. 2000, 41, 5857.

61. Bahekar, R. H.; Rao, A. R. R. Indian J. Hetrocycl. Chem. 1999, 8, 225.

62. Ivachtchenko, A.; Kovalenko, S.; Drushlyak, O. Heterocycl. Commun. 2002, 8, 233.

63. Mahana, H. P.; Mahana, D. P.; Salazer, R.; Valderrama, J. A. ; Saez, E.; Maturana, R. A. Synthesis 2004, 436.

64. Insuasty, B. A.; Torres, H.; Quiroga, J.; Abonía, R.; Rodríguez, R.; Nogueras, M.; Sánchez, A.; Saitz, C.; Alvarez, S. L.; Zacchino, S. A. J. Chil. Chem. Soc. 2006, 51, 927.

65. Rohini, R.; Shanker, K.; Reddy, P. M.; Ho, Y.-P.; Ravinder,V. Eur. J. Med. Chem. 2009, 44, 3330.

66. Vostrova, L. N.; Voronina, T. A.; Karaseva, T. L.; Gernega, S. A.; Ivanov, E. I.; Kirichenko, A. M.; Totrova, M. Y. Khim. Farm. Zh. 1986, 20, 690; Chem. Abstr. 1987, 106, 32976.

67. Prameela, S. N. J.; Hanumanthu, P. Indian J. Chem. 2001, 40B, 430.

68. Lyakhova, E. A.; Gusyeva, Y. A.; Nekhoroshkova, J. V.; Shafran, L. M.; Lyakhov, S. A. Eur. J. Med. Chem. 2009, 44, 3305.

69. Valderrama, J. A.; Pessoa-Mahana, H.; Sarras, G.; Tapia, R. Heterocycles 1999, 51, 2193.

70. Dib, H. H.; Al-Awadi, N. A.; Ibrahim, Y. A.; El-Dusouqui, O. M. Tetrahedron 2003, 59, 9455.

71. Volovenko, Y. M.; Nemazanyi, A. G.; Babichev, F. S. Geol., Khim. Biol. Nauki 1984, 3, 33; Chem. Abstr. 1984, 101, 38376.

72. Mahana, D. P.; Bustos, C. E.; Raipán, J. M.; Pacheco, J. C.; Mahana H. P. Arkivoc 2009, (xii), 131.

73. Martineau, A.; Dejongh, D. C. J. Analytic. Appl. Pyrolysis 1983, 5, 39.

74. Elwan, N. M. Tetrahedron 2004, 60, 1161.

75. Dzvinchuk, I. B.; Lozinskii, M. O. Chem. Heterocycl. Compd. 2005, 41, 1199.

76. O’Shaughnessy, J.; Cunningham, D.; Kavanagh, P.; Leech, D.; McArdle, P.; Aldabbagh, F. Synlett 2004, 2382.

77. Volovenko, Y. M.; Volovnenko, T. A. Chem. Heterocycl. Compd. 2006, 42, 488.

78. Caroti, P.; Ceccotti, C.; Da Settimo, A.; Palla, F.; Primofiore, G. Gazz. Chim. Ital. 1987, 117, 263.

79. Caroti, P.; Ceccotti, C.; Da Settimo, A.; Palla, F.; Primofiore, G. J. Heterocycl. Chem. 1986, 23, 1833.

80. Abd El Latif, F. M.; Barsy, M. A.; Elrady, E. A.; Hassan, M. J. Chem. Res. 1999, 696. 
81. Gokhale, U. V.; Seshadri, S. Dyes and Pigm. 1987, 8, 157.

82. Rajadhyaksha, D. D.; Rangnekar, D. W. J. Chem. Tech. Biotech. 1986, 36, 300.

83. Le, H. P.; Kelbig, A.; Lindauer, A.; Neidlein, R.; Suschitzky, H. J. Chem. Res. 2004, 453.

84. Rangnekar, D. W.; Rajadhyaksha, D. D. Dyes and Pigm. 1986, 7, 365.

85. Elwan, N. M. J. Heterocycl. Chem. 2004, 41, 281.

86. Hammad, M. A.; Kamel, M. M.; Abbasi, M. M.; El-Wassimi, M. T.; Hassan, H. N. A. Pharmazie 1986, 41, 141.

87. Bogdarowcz- Szwed, K.; Czarny, A. J. Prakt. Chem. 1993, 335, 279.

88. Blyumin, E. V.; Volovenko, Y. M.; Neunhoeffer, H.; Shishkina, S. V.; Zubatyuk, R. A.; Shishkin, O. V. Tetrahedron 2002, 58, 5733.

89. Volovenko, Yu. M.; Babichev, F. S.; Nemazanyi, A. G.; Fursii, T. A. U.S.S.R. 1404508, 1988; Chem. Abstr. 1989, 110,8231.

90. Suma, G.; Bahekar, R. H.; Rao, A. R. R. Org. Prep. Proced. Int. 2000, 32, 99.

91. Reddy, K. V.; Mogilaiah, K.; Sreenivasulu, B. Indian J. Chem. 1984, 23B, 1106.

92. Abdelhamid, A. O.; Zohdi, H. F.; Ziada, M. M. Indian J. Chem. 2001, 40B, 284.

93. Hirpara, K.; Patel, S.; Joshi, A.; Parekh, H. Indian J. Heterocycl. Chem. 2004, 13, 221.

94. Romano, C.; de la Cuesta, E.; Avendano, C. J. Org. Chem. 1991, 56, 74.

95. Romano, C.; De La Cuesta, E.; Avendano, C.; Florencio, F.; Sainz-Aparicio, J. Tetrahedron 1988, 44, 7185.

96. Badawey, E.-S. A. M.; Hazzaa, A. A.; Rida, S. M.; Fahmy, H. T. Y. Arch. Pharm. 1992, $325,565$.

97. Ivachtchenko, A.; Kovalenko, S.; Parkhomenko, O.; Chernykh, V. Heterocycl. Commun. 2002, 8, 329.

98. Sarhan, A. E.; El-Sherief, H. A. A.; Mahmoud, A. M. J. Chem. Res. 1996 (S) 4, (M) 116.

99. Sarhan, A. A. O.; Hozien, Z. A.; Mahmoud, A. M.; EI-Sherief, H. A. H. Monatsh. Chem. 1997, 128, 1133.

100.Sarhan, A. A. O. Afinidad 1996, 53, 57.

101.Sarhan, A. A. O.; Hozien, Z. A.; El-Sherief, H. A. H.; Mahmoud, A. M. Polish J. Chem. 1995, 69, 1479.

102.Dhamnaskar, S. V.; Rangnekar, D. W. Dyes Pigm. 1988, 9, 467.

103.Okamoto, Y.; Togo, I.; Kurasawa, Y.; Takagi, K. J. Heterocycl. Chem. 1986, 23, 1829.

104.Dzvinchuk, I. B.; Chernega, A. N.; Povolotskiy, M. I.; Lozinskiy, M. O. Zh. Org. Farm. Khim. 2004, 2, 33; Chem. Abstr. 2005, 145, 356733.

105.Dorokhov, V. A.; Gordeev, M. F.; Demyanets, Z. K.; Vorontsova, L. G.; Kurella, M. G.; Andrianov, V. I.; Rekhlova, O. A. Izv. Akad. Nauk SSSR, Seri. Khim. 1991, 11, 2587; Chem. Abstr. 1992, 117, 26477.

106.Babichev, F. S.; Volovenko, Y. M.; Pereshivana, L. M. Ukr. Khim. Zh. 1983, 49, 1095; Chem. Abstr. 1984, 100, 51533.

107.Brukshtus, A.; Sadauskas, T.; Tumkyavichyus, S. Chem. Heterocycl. Compd. 1996, 32, 371. 108.Koutentis, P. A.; Rees, C. W. J. Chem. Soc., Perkin Trans. 1, 2000, 2601. 
109.Cherkaoui, O.; Essassi, E.; Zniber, R. Tetrahedron Lett. 1990, 31, 5467.

110.Essassi, E. M.; Salem, M.; Viallefont, Ph. Bull. Soc. Chim. Belg. 1994, 103, 57.

111.Hoesl, C. E.; Nefzi, A.; Houghten, R. A. J. Comb. Chem. 2004, 6, 220.

112. Volovenko, Y. M. Chem. Heterocycl. Compd. 1997, 33, 749.

113.Venkataratnam, R. V.; Sayanna, E.; Sujatha, K. Synth. Commun. 1987, 17, 1533.

114.Bilek, P.; Slouka, J. Heterocycl. Commun. 2002, 8, 123.

115.Kruglenko, V. P.; Gnidets, V. P.; Povstyanoi, M. V. Chem. Heterocycl. Compd. 2000, 36, 103.

116.Kruglenko, V. P. Chem. Heterocycl. Compd. 1999, 35, 376.

117.Elmaati, T. M. A.; Said, S. B.; Elenein, N. S. A.; Khodeir, N. M.; Sofan, M. M. J. Heterocycl. Chem. 2003, 40, 481.

118. Moriarty, E.; Aldabbagh, F. Tetrahedron Lett. 2009, 50, 5251.

119.Pratap, R.; Ram, V. J. Tetrahedron Lett. 2007, 48, 5039.

120.Jiang, W.; Tang, J.; Qi, Q.; Sun, Y.; Ye, H.; Fu, D. Dyes Pigm. 2009, 80, 279.

121. Volovenko, Y. M.; Nemazanyi, A. G.; Vesel'skaya, G. L.; Babichev, F. S. Ukr. Khim. Zh. 1987, 53, 1085; Chem. Abstr. 1988, 109, 110333.

122. Rida, S. M.; Soliman, F. S. G.; Badawey, El S. A. M.; El-Ghazzawi, E.; Kader, O.; Kappe, T. J. Heterocycl. Chem. 1988, 25, 1087.

123. Volovnenko, T. A.; Tarasov, A. V.; Volovenko, Y. M. Ukr. Khim. Zh. 2006, 72, 108; Chem. Abstr. 2006, 145, 471448.

124.Tabakovic, I.; Tabakovic, K.; Grujic, R.; Trinajstic, N.; Meic, Z. Heterocycles 1985, 23, 2539.

125.Metwally, M. A.; Etman, H. A. Z. Naturforsch. 1986, $41 B, 486$.

126.Litenko, V. A.; Volovenko, Y. M.; Babichev, F. S. Ukr. Khim. Zh. 1983, 49, 1202; Chem. Abstr. 1984, 101, 72666.

127.Makovetskii, V. P.; Dzvinchuk, I. B.; Volovenko, Y. M.; Svishchuk, A. A. Chem. Heterocycl. Compd. 1980, 2, 164.

128. Islam, I.; Skibo, E. B. J. Org. Chem. 1990, 55, 3195.

129.Skibo, E. B.; Islam, I.; Schulz, W. G.; Zhou, R.; Bess, L.; Boruah, R. Synlett 1996, 297.

130.Schulz, W. G.; Skibo, E. B. J. Med. Chem. 2000, 43, 629.

131.Baklanov, M. V.; Frolov, A. N. Zh. Org. Khim. 1992, 28, 390; Chem. Abstr. 1993, 118, 191629.

132.Baklanov, M. V.; Frolov, A. N. Zh. Org. Khim. 1991, 27, 638; Chem. Abstr. 1991, 115, 183180.

133.Farghaly, T. A.; Abdalla, M. M. Bioorg. Med. Chem. 2009, 17, 8012.

134.Hassan, A. A. Phosphorus, Sulfur and Silicon 1996, 113, 231.

135.Dawood, K. M. J. Heterocycl. Chem. 2005, 42, 221.

136. Reddy, K. V.; Mogilaiah, K.; Sreenivasulu, B. J. Indian Chem. Soc. 1984, 61, 888.

137.Bakhite, E. A.; Al-Sehemi, A. G.; Yamada, Y. J. Heterocycl. Chem. 2005, 42, 1069. 
138.Compernolle, F.; Saleh, M. A.; Toppet, S.; De Buysser, W.; Hoornaert, G. J. Heterocycl. Chem. 1991, 28, 1965.

139. Abdelhamid, A. O.; Awad, A. A. J. Heterocycl. Chem. 2007, 44, 701.

140.Sarhan A. A. O. J. Chin. Chem. Soc. 2000, 4, 1279.

141.Farag, A. M. J. Chem. Res. (S) 1994, 432.

142.Da Settimo, A.; Primofiore, G.; Da Settimo, F.; Pardi, G.; Simorini, F.; Marini, A. M. J. Heterocycl. Chem. 2002, 39, 1007.

143.Davoodnia, A.; Heravi, M. M.; Golshani, E.; Bakavoli, M.; Dehabadi, L. J. Chem. Res. 2007, 257.

144.Volovenko, Y. M.; Shokol, T. V.; Dashkovskaya, E. V.; Babichev, F. S. Ukr. Khim. Zh. 1985, 51, 649; Chem. Abstr. 1986, 104, 19487.

145. Farag, A. M. J. Chem. Res. (S) 1995, 96.

146.Povstyanoi, M. V.; Kruglenko, V. P.; Gnidets, V. P. Zh. Org. Khim. 1984, 20, 1345; Chem. Abstr. 1984, 101, 171216.

147.Cassidy, P. E.; Wallace, R. J.; Aaminabhavi, T. M. Polymer 1986, 27, 1131.

148.Groves, C. L.; Ralph, J. T.; Temple, A. F. J. Heterocycl. Chem. 1987, 24, 27.

149.El-Zohry, M. F.; Mohamed, T. A.; Hussein, E. M. Monatsh. Chem. 2009, 140, 265.

150.Dawood, K. M.; Raslan, A. M.; Farag, A. M. Synth. Commun. 2003, 33, 4079

151. Minkin, V. I.; Komissarov, V. N.; Sayapin, Y. A. Arkivoc 2006 (vii), 439.

152.Elmegeed, G. A. Egypt. J. Chem. 2004, 47, 579; Chem. Abstr. 2006, 146, 338065.

153. Bajwa, J. S.; Sykes, P. J. J. Chem. Soc., Perkin Trans. 1 1980, 1859.

154.Venepalli, B. R.; Aimone, L. D.; Appell, K. C.; Bell, M. R.; Dority, J. A.; Goswami, R.; Hall, P. L.; Kumar, V.; Lawrence, K. B.; Logan, M. E.; Scensny, P. M.; Seelye, J. A.;

Tomczuk, B. E.; Yanni J. M. J. Med. Chem. 1992, 35, 374.

155.Bajwa, J. S.; Sykes, P. J. J. Chem. Soc., Perkin Trans. 1 1980, 2146.

\section{Authors' Biographies}

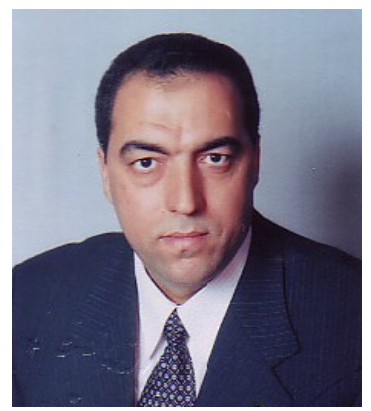

Kamal M. Dawood was born in 1965 in Kafr-Elsheikh, Egypt. He graduated from Cairo University, Egypt in 1987 then he carried out his MSc and PhD studies under the supervision of Professor Ahmad M. Farag, Cairo University. He received his PhD in 1995 in the applications of hydrazonoyl halides in heterocyclic chemistry. In 1997 he was awarded the UNESCO 
Fellowship for one year at Tokyo Institute of Technology (TIT) and collaborated with Prof. Toshio Fuchigami in the field of 'Electrochemical Partial Fluorination of Heterocyclic Compounds'. In 1999, he was awarded the JSPS (Japan Society for Promotion of Science) Fellowship for two years and worked again with Professor Fuchigami at TIT in the same field. He was awarded the Alexander von Humboldt Fellowship at Hanover University in 2004-2005 with Prof. Andreas Kirschning in the field of polymer supported palladium catalyzed cross coupling reactions and in 2007 and 2008 with Prof. Peter Metz at TU-Dresden, Germany, in the field of total synthesis of natural products. In 2002 he promoted to Associate Professor and in May 2007 he was appointed as Professor of Organic chemistry, Faculty of Science, Cairo University. In 2002 he received the Cairo University Award in Chemistry and in 2007 he received the State-Award in Chemistry. He published about 75 scientific papers in distinguished international journals.

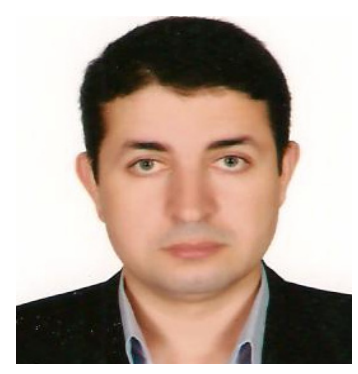

Bakr F. Abdel-Wahab was born in 1978 in Mansoura, Egypt. He is currently a researcher of organic chemistry at National Research Centre, Cairo, Egypt. He has got his B.Sc. in 1999 from Chemistry Department, Faculty of Science, Mansoura University, Egypt. He received his M.Sc. in 2003 from Mansoura University under the supervision of Professor Fathy A. Amer. He has awarded his Ph.D. degree in 2007 from Ain-Shams University, Cairo under the supervision of Professor Maher A. El-Hashash (D.Sc). His current research interests cover the development and mechanistic aspects of organic reactions and their applications in medicinal chemistry. 